\title{
TECHNICAL AND ECONOMIC ASPECTS OF REAL ESTATE PROPERTIES
}

Collective monograph

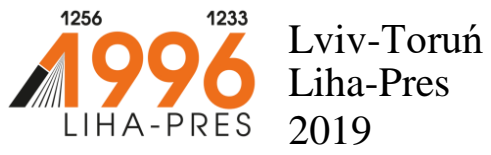




\section{Reviewers:}

Dr inż. Michat Sójka, Dean of the Faculty of Mechanical Engineering of Cuiavian University in Wloclawek (Republic of Poland);

Dr Zbigniew Brenda, Director of Logistics and Technology Institute of Cuiavian University in Wloclawek (Republic of Poland);

Prof. dr hab. Ryszard Strzelecki, Politechnika Gdańska / Gdansk University of Technology (Republic of Poland).

Technical and economic aspects of real estate properties : collective monograph / V. P. Nikolaiev, P. Ye. Hryhorovskyi, V. O. Khyzhniak, G. M. Ryzhakova, etc. - Lviv-Toruń : Liha-Pres, 2019. - 124 p.

ISBN 978-966-397-167-4

\section{SENSE}

Liha-Pres is an international publishing house which belongs to the category "C" according to the classification of Research School for Socio-Economic and Natural Sciences of the Environment (SENSE) [isn: 3943, 1705, 1704, 1703, 1702, 1701; prefixMetCode: 978966397]. Official website www.sense.nl. 


\section{CONTENTS}

QUALITATIVE AND QUANTITATIVE ANALYSIS

OF THE HOUSING STOCK IN UKRAINE

Nikolaiev V.P.

DETERMINATION OF AN OPTIMAL SCOPE OF INSTRUMENTAL EXAMINATIONS DURING CONSTRUCTION AND OPERATION OF BUILDINGS AND STRUCTURES

Hryhorovskyi P. Ye.

ADHERENCE TO CONSUMER RIGHTS AND INCREASE

IN SOCIAL RESPONSIBILITY OF BUSINESSES

IN ACCORDANCE WITH THE EU STANDARDS ON PROTECTION

OF CONSUMER RIGHTS: LESSONS FOR UKRAINE

Khyzhniak V. O.

IMPLEMENTATION OF SCIENTIFIC, ANALYTICAL

AND APPLIED TOOLS OF ORGANIZING INVESTMENT

IN A MODERN DEVELOPMENT SYSTEM

Ryzhakova G. M.

THE EFFECT OF THE BUSINESS ACTIVITY

ON THE CONCENTRATION OF NEW CONSTRUCTION REAL

ESTATE MARKETS

Bielienkova O. Yu.

STUDY OF THE TECHNOLOGY OF STRENGTHENING REINFORCED CONCRETE COLUMNS BY EXTERNAL REINFORCEMENT

Molodid O. S. 101 


\section{QUALITATIVE AND QUANTITATIVE ANALYSIS OF THE HOUSING STOCK IN UKRAINE}

\section{Nikolaiev V. P.}

\section{INTRODUCTION}

The state housing policy of the independent Ukraine, similarly to the one of the former USSR, has always envisaged the state's participation in the provision of housing to citizens. The right to housing and the state's role in the provision of housing to citizens are defined in Article 47 of the 1996 Constitution of Ukraine, which declares that the state creates the conditions under which each citizen shall be able to build their own housing, purchase it or lease it. Vulnerable citizens requiring social protection receive housing from the state and local self-government authorities free of charge or at affordable prices in accordance with the law ${ }^{1}$.

The modern policy of applying private property law to housing displays, as we believe, contradictions between the short-term attractive goals and the long-term negative ramifications of the implementation of the provisions of the current Constitution. While the provision of the population with housing in the process of the almost free-of-charge privatization in the 1990s looked like the state's "gift" for flat dwellers, the prospect of renovating old flats and purchasing new housing at one's own expense and paying the entire cost of the housing and utilities services, especially following the multiple tariff raising in 2015, came to be viewed as an excessive burden for many households. At the same time, most of the inevitable costs for further purchase, maintenance and repair of houses have not yet been recognized by the population, as the respective component was lacking in tariffs and statistics. Provided it is taken into account, the home ownership provided for by the Constitution becomes inaccessible for most of the population.

A need arises to develop new strategies in the housing sphere due to the necessity to properly maintain houses, renovate housing stock and guarantee the sustainable provision of housing to the population.

In Ukrainian scientific literature, the modern policy and state strategies in the housing sphere were studied in the monographs and doctoral theses in various specialties: by V. Bozhanova, 20072, D. Levchynskyi, 2012 ${ }^{3}$,

\footnotetext{
${ }^{1}$ Constitution of Ukraine. // URL: http://www.president.gov.ua/documents/constitution

${ }^{2} \mathrm{~V}$.Yu. Bozhanova. Business mechanism of increasing housing availability for population. Dnepropetrovsk. Science and Education, 2007. - 392 p. (in Ukrainian)
} 
I. Lysov, 2012 , Yu. Mantsevych, 2007 ${ }^{5}$, O. Nepomniashchii, 20136, N. Oliinyk, $2011^{7}$, V. Omelchuk, $2012^{8}$, K.Palyvoda, $2010^{9}$, as well as in other authors' works.

The above-mentioned authors mostly focused on the organizational and financial issues of providing a wider availability of housing, development of housing construction, and search of state mechanisms to provide solutions thereto. In spite of the value of the financing schemes improvements, ways to reduce housing prices and provide relief to certain population categories proposed by them, the problem of the possibility to satisfy the housing needs of all citizens on the basis of constitutional provisions, the Laws of Ukraine and applicable state policy papers has never been raised and remains unsolved.

Special attention should be paid to the monograph by V. Kravchenko, K. Palyvoda, V. Poliachenko ${ }^{10}$, in which the main problem inherent to the housing sphere is specified as the contradiction between the need in housing as prime necessity and the shortage or lack of the possibilities of satisfaction thereof either by an individual or by a social group or even society as a whole which requires the state to assume an active role, various in its mechanisms [10, P. 137]. New views on the problem of housing provision to citizens of Ukraine are found in the publications by T. Nikolaieva ${ }^{11}$,

${ }^{3}$ D.L. Levchynskyi. Government regulation of the investment process of housing stock reconstruction : synopsis of a thesis for the degree of Doctor of Sciences in Economics : 08.00.03, Zaporizhzhia, Classical Private University. 2012. 40 p. (in Ukrainian)

${ }^{4}$ I.V. Lysov. State housing policy of Ukraine and its regions: theory, methodology, practice [Text] : monograph / I.V. Lysov, Academy of Municipal Administration - Donetsk : IuhoVostok Publishing House, 2012. - 399 p. (in Ukrainian)

${ }^{5}$ Yu.M. Mantsevych. Social and economic issues of the development of housing services in Ukraine and the strategy of its improvement: [monograph]. Kyiv. Profi-Inform Publishing House. 2007. - 388 p. (in Ukrainian)

${ }^{6}$ O.M. Nepomniashchii. Methodological framework for forming and implementing state housing policy : synopsis of a thesis for the degree of Doctor of Sciences in State Administration : 25.00.02. Donetsk. Donetsk State University of Management. 2013. - 36 p. (in Ukrainian)

${ }^{7}$ N.I. Oliinyk, State regulation of the housing market in Ukraine. Thesis for the degree of Doctor of Sciences in State Administration, 25.00.02. Kyiv, National Academy of State Administration. 2011. - 391 p. (in Ukrainian)

${ }^{8}$ V.A. Omelchuk. State regulation of the affordable housing market in Ukraine. Thesis for the degree of Doctor of Sciences in Economics 08.00.03. - Economics and National Economy Management. Kyiv. Scientific and Research Institute of Economy. 2012. - 422 p. (in Ukrainian)

${ }^{9}$ K.V. Palyvoda. Monetary resources and financial mechanisms of capital investment into housing construction : synopsis of a thesis for the degree of Doctor of Sciences in Economics : 08.00.08. Kyiv. No publishing house. 2010. - 38 p. (in Ukrainian)

10 V.A. Kravchenko, K.V. Palyvoda V.A. Poliachenko. Fundamentals of housing economics. Kyiv. Osnova. 2007. - P. 416 (in Ukrainian)

${ }^{11}$ T.V. Nikolaieva. Financial and economic mechanism of maintaining and reconstructing housing stock in the context of ownership relations transformation. Scientific bulletin of the National University of the State Tax Office of Ukraine (Economy, Law). / Science editor P.V. Melnik. Kyiv, National University of the State Tax Office of Ukraine. 2012. No. 1 (56). P. $81-85$ (in Ukrainian) 
P. Panteleiev ${ }^{12}$, A. Shcherbyna ${ }^{13}$, where, in contrast to other authors' publications, its connection with the ownership of housing, the necessity to concentrate residential property with the most efficient owners is indicated.

This entails the necessity to study a great number of related issues: the state of the houses and evaluation of the accumulated and subsequent regular needs in capital repairs, full cost of the effective house ownership, definition of the real standards of housing provision, research of citizens' opinion of the necessary reforms. This article's task is to systematize the quantitative and qualitative approaches to the issue of housing stock preservation and sustainable provision of population with housing.

\section{Housing construction and housing provision: quantitative evaluation}

After Ukraine shifted to the liberal state model and the use of market regulation mechanisms, the volumes of housing construction started to be defined no so much by the government's social (housing) policy as by the demographic processes, urbanization and consumer demand, with a restricted use of, as it transpired later, imperfect funding and financing mechanisms. The share of the state and local budgets in the yearly spending on housing construction was declining and is currently less than $1 \%$ (table 1 ).

Table 1

Housing construction in Ukraine since independence

\begin{tabular}{|c|c|c|c|c|c|c|c|}
\hline Years & $\begin{array}{c}\text { Housing } \\
\text { commissioned, } \\
\text { million } \mathbf{~ m}^{\mathbf{2}}\end{array}$ & Years & $\begin{array}{c}\text { Housing } \\
\text { commissioned, } \\
\text { million } \mathbf{~ m}^{\mathbf{2}}\end{array}$ & $\begin{array}{c}\text { Share of } \\
\text { state } \\
\text { funding }\end{array}$ & Years & $\begin{array}{c}\text { Housing } \\
\text { commissioned, } \\
\text { million } \mathbf{~ m}^{\mathbf{2}}\end{array}$ & $\begin{array}{c}\text { Share of } \\
\text { state } \\
\text { funding }\end{array}$ \\
\hline 1992 & 14,1 & 2000 & 5,6 & 1,5 & 2009 & 6,4 & 1,7 \\
\hline 1993 & 12,3 & 2001 & 5,9 & 1,9 & 2010 & 5,0 & 0,3 \\
\hline 1994 & 10,1 & 2002 & 6,1 & 2,2 & 2011 & 7,2 & 0,8 \\
\hline 1995 & 8,7 & 2003 & 6,4 & 4,3 & 2012 & 10,8 & 0,7 \\
\hline 1996 & 6,8 & 2004 & 7,6 & 2,5 & 2013 & 11,2 & 0,5 \\
\hline 1997 & 6,4 & 2005 & 7,8 & 3,6 & 2014 & 9,7 & 0,3 \\
\hline 1998 & 5,8 & 2006 & 8,6 & 2,8 & 2015 & 11,0 & 0,5 \\
\hline 1999 & 6,1 & 2007 & 10,2 & 1,6 & 2016 & 9,4 & 0,3 \\
\hline
\end{tabular}

${ }^{1}$ Since 2014, the temporarily occupied territory of the Autonomous Republic of Crimea, Sevastopol and the antiterrorist operation zone are excluded. As this complicates the further analysis in absolute numbers, further we will have to use the data obtained before 2014 in respective comparisons.

Source: State Statistics Service of Ukraine

${ }^{12}$ P.O. Panteleiev. Investment process of maintaining residential houses. Forming market relations in Ukraine. 2013. No. 11 - P. 108-112 (in Ukrainian)

${ }^{13}$ V.P. Nikolaiev, A.A. Shcherbina. A model of development of a residential property and housing and utilities services market in view of consumers' payment capacities. Construction operations : cross-sectoral scientific and technical collection of works. Kyiv. Research Institute of Building Production. 2017. No. 63/3 - P. 34-41 (in Ukrainian) 
Comparing the indicators of commissioning areas per 1000 individuals in Ukraine and in other post-Soviet republics, Ukraine's lagging behind was and is now obvious (fig. 1). It is largely attributable to the low level of the state's involvement in the direct financing of housing construction or in the support of affordable housing programs (in 2017-2018: Belarus - 25.2\%, Russia $-5.4 \%$, Kazakhstan $-17 \%$ ). In Ukraine, 30.3 thousand $\mathrm{m}^{2}$ of the total area of housing was accepted into service at the state budget costs in 2016 ( $0.3 \%$ of the total amount), which is $42.3 \%$ less than in 2015 . Given these newly built flats have an average area, this will suffice only for 365 families.

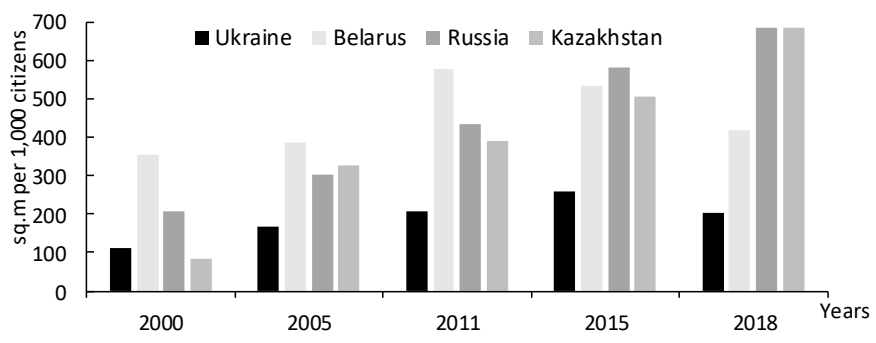

\section{Fig. 1. Commissioning of housing in Ukraine and some CIS countries}

Source: plotted by the author based on the government statistics of respective countries

It is believed that the normal demand for housing in a country can be supported when the average monthly salary reaches the level of the price of $1 \mathrm{~m}^{2}$ of housing. As per the State Statistics Service of Ukraine, the average monthly salary as of the beginning of 2019 amounted to UAH 8,865, while the price of one square meter of housing in the capital was UAH 25,000, and in the regions, it was UAH 10,000 to 20,000 , i.e., several times lower. Ukraine holds one of the lowest places in the world as per the housing affordability index (depending on the information sources).

Thus, the decrease of the state financing lead to the shrinking of the volumes of housing construction two to three times compared to the end of the 80s. Altogether, since independence and until the beginning of 2019, nearly 0.23 billion $\mathrm{m}^{2}$ of new and renovated housing has been commissioned.

The cost of housing construction in the conditions of underdeveloped and non-transparent market relations is representative for the analysis of the falling demand for new housing, as the excessive price of housing also limits this demand (table 2). 
The 2018 statistics show that from UAH 53,247 million of capital investments in housing, UAH 29,345 million, or $55 \%$, were spent on construction, and 8.7 million $\mathrm{m}^{2}$ of housing were commissioned. This means that $1 \mathrm{~m}^{2}$ cost investors UAH 6,120, and construction companies - UAH 3,373 . At the same time, the housing prices were and still are substantially higher, which had to signify a high profitability of housing construction. However, strange as it may seem, according to the official statistics, during all years of independence, building enterprises have been lossmaking, in particular, since 2010 (fig. 2).

Table 2

Cost indicators of housing construction

\begin{tabular}{|c|c|c|c|c|}
\hline Years & $\begin{array}{c}\text { Capital } \\
\text { investments in } \\
\text { housing } \\
\text { constructions, } \\
\text { UAH million }\end{array}$ & $\begin{array}{c}\text { Volume of } \\
\text { performed } \\
\text { construction } \\
\text { works, UAH } \\
\text { million }\end{array}$ & $\begin{array}{c}\text { Total housing } \\
\text { commissioned, } \\
\text { million } \mathbf{~ m}^{\mathbf{2}}\end{array}$ & $\begin{array}{c}\text { New housing } \\
\text { commissioned, } \\
\text { million } \mathbf{~ m}^{2}\end{array}$ \\
\hline 2010 & 25,754 & 6,876 & 8.6 & 8.1 \\
\hline 2014 & 33,177 & 11,292 & 9.7 & 8.8 \\
\hline 2015 & 45,610 & 13,908 & 11.0 & 9.8 \\
\hline 2016 & 42,503 & 18,012 & 9.4 & 8.3 \\
\hline 2017 & 53,372 & 23,730 & 10.2 & 10.2 \\
\hline 2018 & 53,247 & 29,345 & 8.7 & 8.7 \\
\hline
\end{tabular}

Source: State Statistics Service of Ukraine

Thus, the economic mechanism regulation in the housing construction sector could somewhat change the situation on the residential property market.

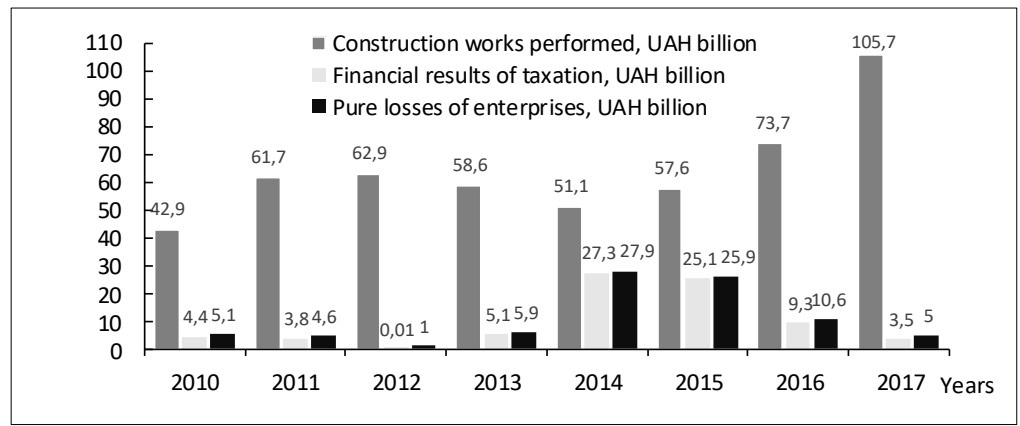

Fig. 2. Losses of housebuilding

Source: State Statistics Service of Ukraine 
As a result of the housing construction rates described above, as of 1 January 2018, the total area of housing stock amounted to 984.8 million $\mathrm{m}^{2}$. Almost entire housing stock $(98.4 \%)$ was concentrated in multi-apartment buildings and single-family houses, the remaining 16.2 million $\mathrm{m}^{2}(1.6 \%)$ - in company dormitories (fig. 3).

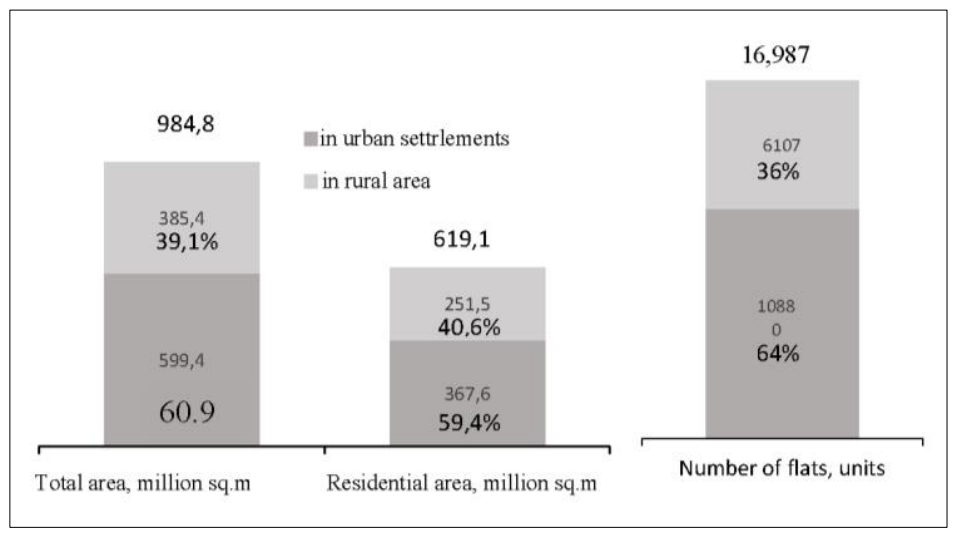

Fig. 3. Housing stock in Ukraine

Source: State Statistics Service of Ukraine

Despite the significant decline in the housing construction, the average availability of housing grew due to the falling population size (fig. 4).

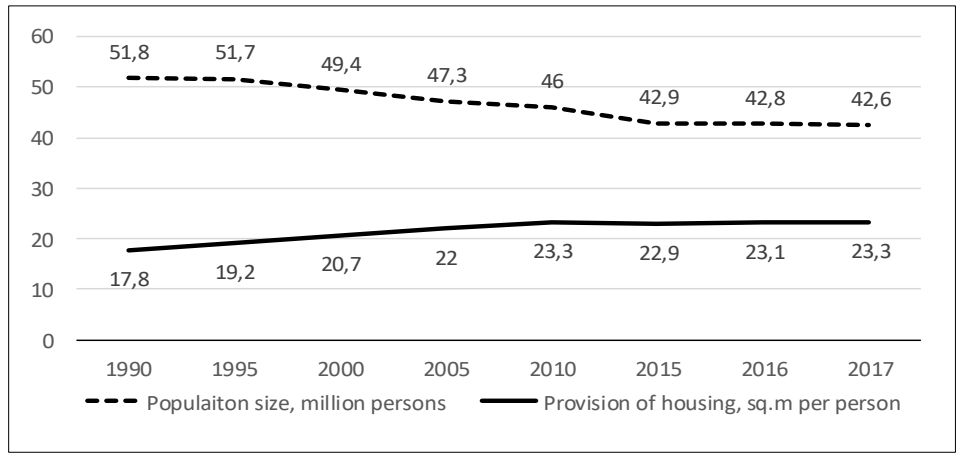

Fig. 4. Population size and provision of housing

Source: State Statistics Service of Ukraine 
Currently, 0.4 flat is available per person. At the same time, there is a waiting list for housing, which has virtually not moved and no data on which has been available since 2015 (table 3). However, the structure of housing stock (the number of residential houses) as per construction year is very disadvantageous in terms of its quality, as its maintenance is very onerous for its dwellers (tables 4, 5).

Table 3

Provision of housing to citizens

\begin{tabular}{|c|c|c|c|c|c|}
\hline \multirow[b]{2}{*}{ Years } & \multicolumn{3}{|c|}{ Flats } & \multirow{2}{*}{$\begin{array}{l}\text { Number of } \\
\text { families on } \\
\text { the housing } \\
\text { waiting list, } \\
\text { thousand }\end{array}$} & \multirow{2}{*}{$\begin{array}{l}\text { Number of } \\
\text { families } \\
\text { provided with } \\
\text { housing, } \\
\text { thousand }\end{array}$} \\
\hline & $\begin{array}{l}\text { Total area, } \\
\text { million } \mathbf{m}^{2}\end{array}$ & $\begin{array}{l}\text { Number, } \\
\text { thousand }\end{array}$ & $\begin{array}{c}\text { Per one } \\
\text { dweller, } \\
\text { unit }\end{array}$ & & \\
\hline 1990 & 922.1 & 17,656 & 0.34 & 2,638 & 235 \\
\hline 1995 & 978.3 & 18,303 & 0.35 & 2,411 & 82 \\
\hline 2000 & $1,015.0$ & 18,921 & 0.38 & 1,765 & 32 \\
\hline 2005 & $1,046.4$ & 19,132 & 0.40 & 1,323 & 20 \\
\hline 2010 & $1,079.5$ & 19,322 & 0.42 & 1,139 & 11 \\
\hline 2015 & 973.8 & 16,886 & 0.39 & - & - \\
\hline 2016 & 977.9 & 16,912 & 0.40 & - & - \\
\hline 2017 & 984.8 & 16,987 & 0.40 & - & - \\
\hline
\end{tabular}

Source: calculated by the author based on the data of the State Statistics Service of Ukraine

Table 4

Distribution of houses by the years of their construction

(as of the beginning of 2011)

\begin{tabular}{|c|c|c|c|c|}
\hline \multirow{2}{*}{ Years } & \multicolumn{2}{|c|}{ Total } & \multirow{2}{*}{ Cities } & \multirow{2}{*}{ Villages } \\
\cline { 2 - 3 } & Units & \% & & \\
\cline { 2 - 3 } & $\mathbf{1 0 , 1 5 9 , 6 3 6}$ & $\mathbf{1 0 0}$ & $\mathbf{4 , 0 5 5 , 3 9 4}$ & $\mathbf{6 , 1 0 4 , 2 4 2}$ \\
\hline before 1919 & 469,326 & 4.6 & 264,879 & 204,447 \\
\hline $1919-1945$ & $1,197,867$ & 11.8 & 441,633 & 756,234 \\
\hline $1946-1960$ & $2,552,198$ & 25.1 & 969,947 & $1,582,251$ \\
\hline $1961-1970$ & $2,445,067$ & 24.1 & 902,251 & $1,542,816$ \\
\hline $1971-1980$ & $1,645,922$ & 16.2 & 625,800 & $1,020,122$ \\
\hline $1981-1990$ & $1,092,574$ & 10.8 & 465,846 & 626,728 \\
\hline since 1991 & 756,682 & 7.4 & 385,038 & 371,644 \\
\hline
\end{tabular}

Source: $:^{14}$ (recent published data).

${ }^{14}$ Housing stock of Ukraine in 2010. State Statistics Service of Ukraine. Kyiv. 2011. 376 p. (in Ukrainian) 
In 2012, the number of houses reached 10150252, in $2013-10169123$, in 2014 - 10147185, and in 2015 - 9082907, in 2016. - 9113051, in 2017.9130197, in $2018-9137304$.

Table 5

Distribution of households by housing developed in different years

\begin{tabular}{|c|c|c|c|}
\hline Years & All households & Urban & Rural \\
\hline before 1950 & 7,3 & 6,2 & 9,5 \\
\hline In 1950s & 11,4 & 8,9 & 16,3 \\
\hline In 1960s & 21,7 & 19,8 & 25,7 \\
\hline In 1970s & 24,5 & 26,0 & 21,5 \\
\hline In 1980s & 24,5 & 27,5 & 18,2 \\
\hline In 1990s & 8,7 & 9,1 & 7,8 \\
\hline after 2000 & 2,3 & 2,4 & 2,2 \\
\hline
\end{tabular}

Source: ${ }^{15}$.

The total mass of the housing stock has aged, and its significant portion has reached the limit of its service life or the term of conducting major repairs and reconstructions.

Thus, the pre-war and post-war housing development built before 1980 $(81.8 \%)$ has reached the standard age to undergo major repairs, which, however, in the light of constant financial problems faced by Ukraine, have not been performed. It is easy to see that not less than $80 \%$ of houses need renovation of some kind or another.

On the other hand, the percentage of the households suffering the excessive degree of wear of their houses reached $64.9 \%$.

To conclude, the downfall of the volumes of housing construction, the onset of the critical age for most of the available housing stock and the low quality of premises have created a serious problem for the sustainable provision of housing for the citizens of Ukraine.

\section{Qualitative analysis of provision of housing to citizens}

Despite the average quantitative definitiveness of the housing stock, an issue emerges to do with the analysis of the quality of available homes and availability of living space in the context of constitutional provisions, public housing policy and the modern meaning of the notion of housing.

According to Article 379 of the Civil Code of Ukraine, housing of a physical person shall be a multi-apartment house, a flat or other premises intended and suitable for permanent residence. Thus, the notion of housing in the civil law encompasses two levels of objects: constructions (multi-

\footnotetext{
${ }^{15}$ Children, women and family in Ukraine. Statistical compilation. State Statistics Service of Ukraine. Kyiv. 2018. - 320 p. (in Ukrainian)
} 
apartment residential houses, manors, cottages, summer houses) and flats designed for long-term service and intended for being dwelled in ${ }^{16}$.

The Civil Code of Ukraine does not directly limit the norm of dwelling or total space per one person, therefore, according to the law, citizen can be co-owners and dwellers of premises with an area smaller than the one provided statutorily. The same applies to landlords, and this situation cannot be deemed acceptable.

Thus, the Housing Code of the Ukrainian $\mathrm{SSR}^{17}$ entrenched a provision on the prohibition of providing housing for two or more families or two or more single individuals in a flat intended for one family, which sometimes take place in practice.

In contrast to the lawmaker, the scientists understand housing not only as constructions, but also as adjacent territory, and not only the premises where people will immediately live, i.e., rooms, but also kitchen, corridor, bathroom, hallway, closets etc. ${ }^{21}$. Thus, in practice we deal with a multilevel, expanded notion of housing which is featured in the Constitution, which requires a comprehensive study and evaluation of its quality.

Scientifically grounded qualitative criteria and standards of housing found in regulatory documents change over time towards technical improvement (safety, energy efficiency, ecological safety) and comfort (availability of amenities). Besides, housing should be viewed not merely as premises fit for permanent or temporary habitation in a completed building, meeting the necessary health and safety and technical regulations, but also as real estate regarded as such as prescribed by the law, which is lawfully owned or used by a certain individual ${ }^{18}$.

Therefore, we believe that the necessary and sufficient criterion for the use of this notion is the concurrent availability of all the mentioned features or the conformity with all the listed criteria.

Consequently, the following houses cannot be considered as housing:

- ones which have been built and are used out of accordance with technical regulations;

- ones which do not meet health and safety norms, are situated in an unsafe and insalubrious environment;

${ }^{16}$ Civil Code of Ukraine: Scientific and Practical Commentary / under general editorship of Ye.O. Kharytonov, O.I. Kharytonova, N.Yu. Holubieva. - Kyiv: All-Ukrainian Editors' Association "Legal Entity", 2008. - 740 p.

17 Housing Code of the Ukrainian SSR [electronic resource]. - Access mode: https://zakon.rada.gov.ua/laws/show/5464-10.

${ }^{18}$ Yu.S. Lepekh. Right to housing as an object of administrative and legal regulation / Yu.S. Lepekh // Scientific newsletter of Lviv State University of Internal Affairs. - 2012. No. 3 - P. 244-251. http://www2.lvduvs.edu.ua/documents_pdf/visnyky/nvsy/ 03_2012/ 12lyusapr.pdf. 
- ones in which flats do not meet the regulations on provision of living space to their tenants;

- have not been accepted for operation and are mismanaged.

A matter worth to be mentioned separately is the acceptance of houses and flats into operation without the provision of amenities, which contradicts the essence of the concept of housing operation as its readiness to be used as intended. That is to say, in this case we cannot deem the respective citizens' constitutional right respective to housing to be properly exercised ${ }^{19}$. Flats' unreadiness distorts their value (price), which, as per expert assessment, increases by 20 to $30 \%$ due to their subsequent improvement, which has to be reflected in statistics.

Therefore, the state (local authorities) has to regulate the mandatory monitoring and control of the state of residential houses and premises for their conformity with the set of criteria allowing them to be deemed as housing and take measures to ensure such compliance.

On the other hand, we have to reconsider the complex and imperfect system of housing quality evaluation and control. The notion of the quality of a construction object includes its compliance with certain regulatory requirements at the moment of commissioning, as well as preserving this (or other regulatory) compliance throughout its whole operational phase already as a real estate item. While at the first stage quality control has to be ensured by a system of planning and design, construction appraisal and surveillance, subsequently in practice such control and surveillance became significantly weaker without being properly regulated.

As per the State Classifier of Buildings and Constructions, multiapartment buildings are houses having three and more flats, which are divided into three subclasses: multi-apartment buildings of mass development, individual high-comfort multi-apartment buildings, and hoteltype residential houses ${ }^{20}$. More precise characteristics of such houses are provided in the State Construction Regulations (SCR).

Thus, SCR B.2.2-15-2005 "Houses and Constructions. Dwelling Houses. Fundamental Provisions" 21 regulates the quality of flat planning, the flat space and the height of the ceilings (table 6).

${ }^{19}$ Yu.S. Lepekh. Right to housing as an object of administrative and legal regulation / Yu.S. Lepekh // Scientific newsletter of Lviv State University of Internal Affairs. - 2012. No. 3 - P. 244-251. http://www2.lvduvs.edu.ua/documents_pdf/visnyky/nvsy/ 03_2012/ 12lyusapr.pdf.

${ }^{20}$ State Classifier of Buildings and Constructions SC 018-2000 [electronic resource]. Access mode: https://zakon.rada.gov.ua/rada/show/va507565-00/.

${ }_{21}$ State Construction Regulation B.2.2-15-2005 Houses and Constructions. Dwelling Houses. Fundamental provisions [electronic resource]. - Access mode: https://zakon.rada.gov.ua/rada/show/v0175667-05/sp:wide/ 
Characteristics of flat in houses

\begin{tabular}{|c|c|c|c|c|c|}
\hline & \multicolumn{5}{|c|}{ Number of rooms } \\
\cline { 2 - 6 } & $\mathbf{1}$ & $\mathbf{2}$ & $\mathbf{3}$ & $\mathbf{4}$ & $\mathbf{5}$ \\
\hline Higher and lower limit of space, $\mathrm{m}^{2}$ & $30-40$ & $48-58$ & $60-70$ & $74-85$ & $92-98$ \\
\hline
\end{tabular}

Source: ${ }^{8}$

The mentioned document does not provide for the class of unusable housing; however, in practice such houses and premises, i.e. those, which do not meet regulatory requirements, exist.

The main document regulating the compliance with performance specification (regarding maintenance, routine and major repairs and reconstruction) is the Rules for Maintaining Residential Houses and Adjacent Territories ${ }^{22}$.

Analyzing the document, we can identify the main characteristics of residential houses to undergo qualitative analysis: the construction and state of ground work, walls and flooring, roofs, facades; thermotechnical characteristics of protection structures; equipment, construction and state of installations and lifts; size of the adjacent territory, amount and type of planted land; availability of fire safety systems; availability of a utility metering system; availability of special service equipment (video surveillance, security system etc.). For each structural element of a building or utility equipment part, a period of efficient service is determined; however, no such period is provided for management practice. Most performance indicators, which are not sufficient for operating management, are reflected in the technical passport of the house stored at the major-domo. As a rule, no other necessary documentation is available.

Residential premises' inhabitability, or the appropriateness of classifying premises as residential has to be determined by routine inspection of residential houses, which has to be conducted on the basis of the Provision on the procedure of inspecting the state of residential houses to estimate their compliance with sanitary and technical requirements and recognizing residential houses and residential premises uninhabitable ${ }^{23}$. In practice such

\footnotetext{
${ }^{22}$ Rules for Maintaining Residential Houses and Adjacent Territories. Order of the State Committee of Ukraine for Housing and Utility Services No.76 dated 17 May 2005 [electronic resource]. - Access mode: https://zakon.rada.gov.ua/laws/show/z0927-05.

${ }^{23}$ Provision on the procedure of inspecting the state of residential houses to estimate their compliance with sanitary and technical requirements and recognizing residential houses and residential premises uninhabitable approved by the Decree of the Council of Ministers of the Ukrainian SSR dated 26 April 1984 No.189 [electronic resource]. - Access mode: https://zakon.rada.gov.ua/laws/show/189-84-ח.
} 
inspections are not conducted systematically, which distorts the statistical data on the state of houses.

The peculiarity of forming the domestic standard housing stock contributed to the emergence of such group feature of a house as development type characterizing houses by a combination of indicators: development year, construction technology (panel, pre-engineered, brick houses), architectural features, proportion of such houses in the housing stock. The development type determines the largest groups of houses in the housing stock of big cities and can be used to qualitatively characterize them. Development type-based management facilitates the solution of the problems connected with maintenance and repairs of the houses.

The represented data lead to the conclusion that houses utilized by most citizens were built before the current norms have been introduced, do not comply with modern quality requirements and need major repairs, modernization or reconstruction. This is corroborated by statistical data on the improvement (equipment) of flats in houses provided in Table 7.

Table 7

Equipment of housing

\begin{tabular}{|c|c|c|c|c|c|}
\hline \multirow{2}{*}{ Years } & \multicolumn{5}{|c|}{ Share of the total area equipped with } \\
\cline { 2 - 6 } & water supply & sewage & $\begin{array}{c}\text { central } \\
\text { heating }\end{array}$ & gas supply & hot water supply \\
\hline 1995 & 50.5 & 47.3 & 47.9 & 79.9 & 35.0 \\
\hline 2000 & 54.2 & 51.4 & 52.8 & 81.9 & 38.6 \\
\hline 2005 & 56.2 & 53.8 & 56.2 & 82.6 & 40.0 \\
\hline 2010 & 59.6 & 57.5 & 62.1 & 83.2 & 43.1 \\
\hline 2015 & 60.8 & 58.8 & 68.7 & 83.3 & 47.0 \\
\hline 2016 & 61.2 & 59.2 & 68.9 & 83.1 & 47.0 \\
\hline 2017 & 61.8 & 59.8 & 69.1 & 83.1 & 47.5 \\
\hline
\end{tabular}

Source: State Statistics Service of Ukraine

The table demonstrates that a large proportion of dwellings does not meet the modern requirements to quality housing. This means that facilitation of bringing the quality of housing of all citizens in line with regulatory requirements should be a major endeavor.

It is also necessary to ensure the compliance with sanitary and hygienic regulations, which includes a wide range of requirements as to insolation, natural illumination, ventilation, ionization, microclimate and noise protection of premises in residential houses, set forth by sanitary and hygienic regulations, state standards, rules of urban and rural planning and 
development, in particular by the ones approved by the Order of the Ministry of Health of Ukraine ${ }^{24}$.

Further, according to the Law of Ukraine "On the Fundamentals of Social Protection of the Homeless Citizens and Gutter Children" it is believed that homeless people include individuals living in unfinished buildings, other premises undesignated or unsuitable for living, including residential premises in the state of disrepair ${ }^{25}$.

The latest statistical data for 2014 indicated that the number of residential facilities under construction reached 3,823. The situation with the flats and houses which have not been accepted into service but have been occupied is also complicated, as their monitoring and surveillance on the local level is necessary (earlier we have discussed the non-correspondence of shell-andcore flats accepted into service to the notion of housing). Similarly, the dates and the fact of acceptance of a construction object into service and property rights registration also require comprehensive control.

The monitoring of the housing stock state in dynamics also need to be improved substantially. The methodology of displaying the state and qualitative dynamics of housing stock is questionable: it indicates a relative stability of the spaces of old and failing housing stock along with a drastic fall of its de-commissioning, especially considering the low rates of houses rejuvenation. The objects and spaces of such houses should be clarified and confirmed, and the regulatory requirements for inspection of such houses should be implemented.

The above documents, however, do not regulate the conditions of occupation of flats of different forms of property, when even a quality housing in a quality house and environment loses its quality when overpopulated. Resettlement of citizens in various premises is very diverse (table 8 ).

Table 8

Irregularity in resettlement of citizens in premises of various area

\begin{tabular}{|c|c|c|c|}
\hline \multirow{2}{*}{$\begin{array}{c}\text { Living space area per one } \\
\text { individual, } \mathbf{~ m}^{\mathbf{2}}\end{array}$} & \multicolumn{3}{|c|}{ Share of individuals provided with living space, \% } \\
\cline { 2 - 4 } & countrywide & in urban settlements & in rural areas \\
\hline below 7.5 & 9.1 & 11.1 & 5.2 \\
\hline $7.5-9.0$ & 5.0 & 5.4 & 3.9 \\
\hline $9.01-13.65$ & 24.7 & 26.4 & 21.2 \\
\hline above 13.65 & 61.2 & 57.1 & 69.7 \\
\hline
\end{tabular}

Source: ${ }^{27}$.

${ }^{24}$ Order of the Ministry of Health of Ukraine dated 19 June 1996 No.173 "On the Approval of State Sanitary Rules for Settlement Planning and Development” [electronic resource]. Access mode: https://zakon.rada.gov.ua/laws/show/z0379-96.

${ }^{25}$ The Law of Ukraine "On the Fundamentals of Social Protection of the Homeless Citizens and Gutter Children" dated 02 June 2005 No. 2623-IV [electronic resource]. - Access mode: https://zakon.rada.gov.ua/laws/show/2623-15. 
The table shows that $38.8 \%$ of individuals are not provided with even the statutory living space of $13.65 \mathrm{~m}^{2}$. There is a differentiation in the ratio between the number of rooms and members of a household. As much as $63.8 \%$ of one-room flats are inhabited by two or more persons, $42.9 \%$ of two-room flats are inhabited by three and more persons, $24.1 \%$ three-room flats are inhabited by four and more persons. At the same time, a significant proportion of individuals live in flats where the number of rooms exceeds the number of household members. For example, only one person lives in $17.3 \%$ of three-room flats; one or two persons live in $43.8 \%$ of flats with four or more rooms.

Besides, several historically shaped norms of housing provision are in use in Ukraine, which, in our opinion, do not have sufficient scientific justification and need to be reviewed and generalized.

As per the provisions of the effective Housing Code of the Ukrainian $\mathrm{SSR}^{17}$ on the provision of flats for citizens' use by the state and the "Rules of Keeping the Inventory of Citizens Requiring Improvement of Living Conditions and Provision of Dwelling Premises to Them in the Ukrainian SSR" ${ }^{26}$, the following limits were defined: not more than $13.65 \mathrm{~m}^{2}$ of living space per one person, but not less than the average level of living space securing in the given settlement. The Law of Ukraine "On Privatization of State Housing Fund" ${ }^{27}$ defines that the norms are $21 \mathrm{~m}^{2}$ of the total space per one individual plus additional $10 \mathrm{~m}^{2}$ per family.

As for social housing, the Cabinet of Ministers of Ukraine by its Resolution No. 219 dated 19.03.2008 "On Setting Provisional Standards for Provision with Social Housing" has established that the norm for citizens residing in social dormitories is $6 \mathrm{~m}^{2}$ per one person, in flats and one-flat houses this norm is $22 \mathrm{~m}^{2}$ of a total area per family of two and additionally $9.3 \mathrm{~m}^{2}$ per each next family member ${ }^{28}$. On this ground, local selfgovernment bodies could develop their norms in view of specific conditions. However, as it's known, the development of social housing was not widely adopted.

Instead, according to the ongoing affordable housing program, state support in providing citizens with their own housing started to be provided

${ }^{26}$ Decree of the Council of Ministers of the Ukrainian SSR and Ukrainian Trade Union dated 11 December 1984 No.470 "On Approval of the Rules of Keeping the Inventory of Citizens Requiring Improvement of Living Conditions and Provision of Dwelling Premises to Them in the Ukrainian SSR" [electronic resource]. - Access mode: https://zakon.rada.gov.ua/ laws/show/470-84-ח.

${ }^{27}$ The Law of Ukraine "On Privatization of State Housing Fund" [electronic resource]. Access mode: https://zakon.rada.gov.ua/laws/show/2482-12.

${ }^{28}$ Resolution of the Cabinet of Ministers of Ukraine dated 19.03.2008 No. 219 "On Setting Provisional Standards for Provision with Social Housing" [electronic resource]. - Access mode: https://zakon.rada.gov.ua/laws/show/219-2008-п. 
in limited amounts at the rate of not more than $21 \mathrm{~m}^{2}$ of total housing area per one person plus $10.5 \mathrm{~m}^{2}$ per family additionally ${ }^{29}$. In such a case, claimants had to own not more than $13.65 \mathrm{~m}^{2}$ of housing space. A total of 3,771 flats were provided in the period from 2010 to 2017.

Thus, monitoring and surveillance of citizens' provision with housing requires the due consideration of a number of criteria and limitations as to the quality of housing. The main groups of such criteria and limitations are concerned with the environment, house, flat and density of occupation. Considering the non-compliance to the regulations, the quality housing stock and citizens' provision with housing will have lower quantitative characteristics in terms of the housing space.

\section{CONCLUSTIONS}

1. The current situation with the housing stock state and spending power of the majority of population of Ukraine testifies, on the one hand, the necessity to re-orientate toward s the strategy of rebuilding and renewal of the available housing stock, and on the other hand - the necessity to strengthen the state's role in this process. To work out specific strategies for financial sources and legal mechanisms and considering the scale of the problem, we have to evaluate the capacities of separate groups of flat owners, condominium associations, as well as communities, state, and private investors to maintain, use and renew residential property.

2. When renewing housing stock, attention should be paid to the improvement of its quality. Ukrainian legislation lacks a single procedure to recognize premises as inhabitable, as well as the requirements to be met by residential property. Similarly, there is no single procedure for the necessary control and recognition of residential premises as uninhabitable. Accordingly, no reliable data on the inappropriate state of houses and adjacent territories are available, in particular, for different settlements and houses of all forms of ownership. This artificially overrates the average statistic level of citizen's provision with housing.

3. The article demonstrates that a significant proportion of living spaces apparently cannot be considered residential premises. Thus, the state housing policy has to task itself with bringing the residential spaces used by individuals in compliance with current requirements to the quality of residential property. It is expedient to introduce a single norm to regulate the minimum of quality residential area per one person, which would be taken into account both in designing and construction, and registering for the

\footnotetext{
${ }^{29}$ Resolution of the Cabinet of Ministers of Ukraine dated 11.02.2009 No. 140 "Procedure of State Support to Provide Citizens with Affordable Housing". https://zakon.rada.gov.ua/laws/ show/140-2009-ח
} 
entitlement to receive a flat from the state, assistance in purchasing affordable housing, as well as in planning measures of state support for improving housing quality. The limits for such minimum should not be prescriptive but should rather be determined through calculations and consideration of households' capability to properly maintain such housing, including its repairs.

\section{SUMMARY}

The paper analyzes the strategies and results of housing policy in Ukraine in terms of construction and maintenance of buildings and housing provision to citizens in accordance with the Constitution.

The whole housing stock in Ukraine is now practically private. In the 1990s most of the flats in the multi-apartment buildings have been privatized by the tenants free of charge. Social housing stock is almost absent. The new construction is decreasing. The share of public financing in housing construction is less than 1 per cent. About $80 \%$ of all buildings in the cities have been built earlier than 1980, are not yet repaired and require urgent modernization with the cost equal to the actual State budget revenue. By the law of 2015, the responsibility for carrying out capital repairs has been transferred to the tenants who are co-owners of the buildings. The tariff for housing services does not include the component of capital repairs. Houses in the worst condition are inhabited by the poorest families which have no means to maintain and repair their houses because one half of all families in the country receive subsidies to pay their utility bills. However, in most countries, residential subsidies do not apply to real estate owners.

In conditions of low citizen's solvency there is a direct relationship between the level of state presence in the residential sector and the improvement of housing provision. At the same time, the necessity of rational attraction of solvent citizens to housing construction and maintenance is obvious. Taking into account other urgent and costly needs to maintain public infrastructure, the State is also unable to accumulate sufficient funds to renovate the housing stock. At the same time, there is the issue of the justice of additional state assistance to homeowners for repairing their assets at the expense of all taxpayers. Another question is how to operate this private property on the market.

In addition to the quantitative goals of citizen's housing provision, the quality of houses and flats must be analyzed. The approach to determining the notion of "housing" based solely on the characteristics of the living area of the houses without quality analysis and actual use is insufficient to assess the level of citizen's housing provision. The data shows that the houses of the majority of citizens do not meet the modern quality requirements and require not only capital repair but modernization or reconstruction. Also, the 
resettlement of citizens in dwellings is characterized by considerable differentiation and should be monitored. The standards of living space provision should also be resettled.

Thus, the main housing sector problem is the possible mismatch between the housing need as a vital necessity and the lack of opportunities for its satisfaction by an individual, social group or society, which requires state regulation and redistribution of necessary resources.

The following problems require analysis and solution at the national and local levels: assessment of the housing stock and calculation of accumulated needs for its renewal, the full cost of housing ownership and household's solvency in terms of self-financing, formulation of an appropriate strategy of public policy in the housing sector and its realization instruments.

Ukrainian Governments that frequently replace each other are afraid to raise this problem, which requires extraordinary decisions. It becomes obvious that homeowners are mostly inefficient, but the idea of reprivatization can cause social rejection. There are no analogues in the history or in other post-Soviet countries, where either the condition of privatized houses was better, or household incomes were higher, or state aid was regular and where, due to the tariff, funds for capital repairs have always been accumulated and used.

\section{REFERENCES}

1. Constitution of Ukraine. // URL: http://www.president.gov.ua/ documents/constitution.

2. V.Yu. Bozhanova. Business mechanism of increasing housing availability for population. Dnepropetrovsk. Science and Education, 2007. 392 p. (in Ukrainian)

3. D.L. Levchynskyi. Government regulation of the investment process of housing stock reconstruction : synopsis of a thesis for the degree of Doctor of Economics : 08.00.03, Zaporizhzhia, Classical Private University. 2012. 40 p. (in Ukrainian)

4. I.V. Lysov. State housing policy of Ukraine and its regions: theory, methodology, practice [Text] : monograph / I.V. Lysov, Academy of Municipal Administration - Donetsk : Iuho-Vostok Publishing House, 2012. - 399 p. (in Ukrainian)

5. Yu.M. Mantsevych. Social and economic issues of the development of housing services in Ukraine and the strategy of its improvement: [monograph]. Kyiv. Profi-Inform Publishing House. 2007. - 388 p. (in Ukrainian)

6. O.M. Nepomniashchii. Methodological framework for forming and implementing state housing policy : synopsis of a thesis for the degree of 
Doctor of Sciences in State Administration : 25.00.02. Donetsk. Donetsk State University of Management. 2013. - 36 p. (in Ukrainian)

7. N.I. Oliinyk, State regulation of the housing market in Ukraine. Thesis for the degree of Doctor of Sciences in State Administration, 25.00.02. Kyiv, National Academy of State Administration. 2011. - 391 p. (in Ukrainian)

8. V.A. Omelchuk. State regulation of the affordable housing market in Ukraine. Thesis for the degree of Doctor of Sciences in Economics 08.00.03. - Economics and National Economy Management. Kyiv. Scientific and Research Institute of Economy. 2012. - 422 p. (in Ukrainian)

9. K.V. Palyvoda. Monetary resources and financial mechanisms of capital investment into housing construction : synopsis of a thesis for the degree of Doctor of Sciences in Economics : 08.00.08. Kyiv. No publishing house. 2010. - 38 p. (in Ukrainian)

10. V.A. Kravchenko, K.V. Palyvoda V.A. Poliachenko. Fundamentals of housing economics. Kyiv. Osnova. 2007. - 416 p. (in Ukrainian)

11. T.V. Nikolaieva. Financial and economic mechanism of maintaining and reconstructing housing stock in the context of ownership relations transformation. Scientific bulletin of the National University of the State Tax Office of Ukraine (Economy, Law). I Science editor P.V. Melnik. Kyiv, National University of the State Tax Office of Ukraine. 2012. No. 1 (56). - P.81 - 85 (in Ukrainian)

12. P.O. Panteleiev. Investment process of maintaining residential houses. Forming market relations in Ukraine. 2013. No. 11 - P. 108-112 (in Ukrainian)

13. V.P. Nikolaiev, A.A. Shcherbina. A model of development of a residential property and housing and utilities services market in view of consumers' payment capacities. Construction operations : cross-sectoral scientific and technical collection of works. Kyiv. Research Institute of Building Production. 2017. No. 63/3 - P. 34-41 (in Ukrainian)

14. Housing stock of Ukraine in 2010. State Statistics Service of Ukraine. Kyiv. 2011. - 376 p. (in Ukrainian)

15. Children, women and family in Ukraine. Statistical compilation. State Statistics Service of Ukraine. Kyiv. 2018. - 320 p. (in Ukrainian)

16. Civil Code of Ukraine: Scientific and Practical Commentary / under general editorship of Ye.O. Kharytonov, O.I. Kharytonova, N.Yu. Holubieva. - Kyiv: All-Ukrainian Editors' Association "Legal Entity", 2008. - 740 p.

17. Housing Code of the Ukrainian SSR [electronic resource]. Access mode: https://zakon.rada.gov.ua/laws/show/5464-10.

18. Yu.S. Lepekh. Right to housing as an object of administrative and legal regulation / Yu.S. Lepekh // Scientific newsletter of Lviv State 
University of Internal Affairs. - 2012. - No. 3 - P. 244-251. http://www2.lvduvs.edu.ua/documents_pdf/visnyky/nvsy/03_2012/12lyusap r.pdf.

19. D.O. Kharchenko. State regulation of the enforcement of housing rights of citizens of Ukraine / D.O. Kharchenko, M.S. Kuibida. // Democratic Governance. - 2016. - Issue 16-17. [electronic resource]. Access mode: http://nbuv.gov.ua/UJRN/DeVr_2016_16-17_14.

20. State Classifier of Buildings and Constructions SC 018-2000 [electronic resource]. - Access mode: https://zakon.rada.gov.ua/rada/ show/va507565-00/.

21. State Construction Regulation B.2.2-15-2005 Houses and Constructions. Dwelling Houses. Fundamental provisions [electronic resource]. - Access mode: https://zakon.rada.gov.ua/rada/show/v017566705/sp:wide/.

22. Rules for Maintaining Residential Houses and Adjacent Territories. Order of the State Committee of Ukraine for Housing and Utility Services No. 76 dated 17 May 2005 [electronic resource]. - Access mode: https://zakon.rada.gov.ua/laws/show/z0927-05.

23. Provision on the procedure of inspecting the state of residential houses to estimate their compliance with sanitary and technical requirements and recognizing residential houses and residential premises uninhabitable approved by the Decree of the Council of Ministers of the Ukrainian SSR dated 26 April 1984 No.189 [electronic resource]. - Access mode: https://zakon.rada.gov.ua/laws/show/189-84-п.

24. Order of the Ministry of Health of Ukraine dated 19 June 1996 No.173 "On the Approval of State Sanitary Rules for Settlement Planning and Development" [electronic resource]. - Access mode: https://zakon.rada.gov.ua/laws/show/z0379-96.

25. The Law of Ukraine "On the Fundamentals of Social Protection of the Homeless Citizens and Gutter Children" dated 02 June 2005 No. 2623-IV [electronic resource]. - Access mode: https://zakon.rada.gov.ua/ laws/show/2623-15.

26. Decree of the Council of Ministers of the Ukrainian SSR and Ukrainian Trade Union dated 11 December 1984 No.470 “On Approval of the Rules of Keeping the Inventory of Citizens Requiring Improvement of Living Conditions and Provision of Dwelling Premises to Them in the Ukrainian SSR" [electronic resource]. - Access mode: https://zakon.rada.gov.ua/laws/show/470-84-ח.

27. The Law of Ukraine "On Privatization of State Housing Fund" [electronic resource]. - Access mode: https://zakon.rada.gov.ua/ laws/show/2482-12. 
28. Resolution of the Cabinet of Ministers of Ukraine dated 19.03.2008 No. 219 "On Setting Provisional Standards for Provision with Social Housing" [electronic resource]. - Access mode: https://zakon.rada.gov.ua/laws/show/219-2008-ח.

29. Resolution of the Cabinet of Ministers of Ukraine dated 11.02.2009 No. 140 "Procedure of State Support to Provide Citizens with Affordable Housing”. https://zakon.rada.gov.ua/laws/show/140-2009-ח

30. L.M. Bohoslovska. The notion of the constitutional right of a human and citizen to housing in Ukraine / L.M. Bohoslovska // Scientific newsletter of Dnipropetrovsk State University of Internal Affairs. - 2009. No. 1 - P. 55-63.

31. Children, women and family in Ukraine. Data as of November 2017. [electronic resource]. - Access mode: http://www.ukrstat.gov.ua/druk/ publicat/kat_u/2018/zb/09/DJS_2018_pdf.pdf.

\section{Information about the author: \\ Nikolaiev V.P.,}

Doctor of Economics, Professor,

National Academy of State Administration under the President of Ukraine 20, Antona Tsedika str., Kyiv, 03057, Ukraine 


\section{DETERMINATION OF AN OPTIMAL SCOPE OF INSTRUMENTAL EXAMINATIONS DURING CONSTRUCTION AND OPERATION OF BUILDINGS AND STRUCTURES}

\section{Hryhorovskyi P. Ye.}

\section{INTRODUCTION}

Research into interactions between construction activities, surrounding territories and neighboring developed areas is an urgent problem when natural and man-caused processes are studied and coped with during construction and operation of buildings and structures. Defects and damages of buildings that have not been detected and corrected in good time result in deformations. In addition to material outlays on recovery of structure characteristics their effects are detrimental to the natural and social environment. Therefore the prompt evaluation of building conditions, the forecasting of trends in development of defects and damages and the elaboration of measures on their stabilization or removal are very important. For that a mechanism of destruction and wearing of structural elements during construction and operation activities shall be understood and the opportunity of estimation of effects of environmental factors shall exist. For this purpose the objective data measured and collected with the use of instrumentation are vital.

External factors are classified to natural and man-caused ones. The natural factors include atmospheric, climatic, ground, biological and seismic ones. The atmospheric, biological and ground conditions are of particular interest as for the last decades they are under significant man-caused influence. The work concerns with the principal natural and man-caused factors, in particular, deformations, landslides, underflooding and vibrations that have destructive effects on the operating availability of buildings and structures. The recommendations on determination of an optimal scope of instrumental measurements have been elaborated for such objects that are under construction or operation.

Deformation processes are results of untimely detected defects and damages of building elements. Duration and sizes of defects in an object substantially depend on soil types at its base and types of deformation depend on structural features of buildings. Under the action of building weight and other vertical loads the base soils contract and that results in settlement of the foundation. Soils under foundations have various physical and mechanical properties and sizes of foundation settlements are various as 
their loads are not the same and these differences may result in deformations of construction structures.

Slides of buildings and structures that is their horizontal displacements occur under horizontal loads which also result in deformation of elements. Slides occur when the stability of slopes is disturbed by man-caused or natural processes and when soil cohesion forces are less than the gravity. The rate of sliding of soil masses may be hardly noticeable or up to some meters per second ${ }^{1}$. At that intensification and formation of deep block slides of squeezing and slipping development of smallest surface slides of slipping, visco-plastic flow, hydrodynamic destruction and sudden rarefaction are possible.

Underflooding is a process of natural or man-caused nature that is dangerous for buildings $s^{2,3}$. The man-caused causes of underflooding are as follows: changes in conditions of surface flows during earthwork on vertical grading or backfilling of natural drains and ravines; leaks from water utilities and storm sewages, artificial ponds; disturbances of surface water and groundwater flows, significant breaks between earthwork and construction work; infiltration of process water; decreased evaporation under buildings and pavements; groundwater damming in coastal or riverside areas; barrage effects during construction of buried underground structures.

Negative consequences of underfloodings are related with the following: subsidences and cavities of the earth's surface which are created due to compacting of wetted soils at the bases of buildings; hydrodynamic rarefaction of soils that becomes apparent as soil removals on slopes or soil ejections into construction excavations; creation and intensification of sliding, karst, karst-suffusion, erosion and other geologic dangers with corrosion destruction of building foundations and basements, flooding of cellars, hoistways, underground structures and utilities, terrain swamping.

Vibrations, whose main external source is rail transport (the Metro, tramlines and railways), may significantly exceed the allowable limits. Levels and ranges of vibration frequencies in various points of building depend on a generation source, soil properties and structure characteristics ${ }^{4,5}$. The peak

\footnotetext{
${ }^{1}$ National report on the state of man-caused and natural safety in Ukraine in 2014. The State Emergency Service of Ukraine. Kyiv, 2015

${ }^{2}$ Recommendations on estimation of geological risks in the territory of the city of Moscow

${ }^{3}$ SP 11-105-97 System of normative documents in the construction industry. Code of regulations on engineering surveys for the construction industry. Part II. Regulations on production of work in the regions of development of dangerous geological or engineering and geological processes.

${ }^{4}$ GOST R 52892-2007. Vibration and shock. Vibration of buildings. Measurement of vibration and evaluation of its effects on structure. - M. : Standartinform, 2008.

${ }^{5}$ Osypov O.F. Construction under conditions of urban development. Experience and prospects / O.F. Osypov, I.T. Hladun // Urban and territorial planning : coll. sci.-techn. art. K. : KNUBA, 2004. - No. 12. - P. 9.18.
} 
velocity value is a vibration parameter that correlates with the risk of building structures damages in the best way. This parameter characterizes the energy of seismic waves which affect structures. At the peak velocity value the risk of damage depends on factors related to the frequency spectrum of vibrations. Therefore vibrations are estimated on the basis of the dominant component in the frequency spectrum.

During construction under constrained conditions driving piles and digging foundation pits shall not affect the existing buildings and vibrations shall not exceed the allowable level. The building conditions shall be supervised before, during and after piling work as well as before stabilization of deformations ${ }^{6}$. The most significant loads are dynamic ones due to transport movement. It is difficult to determine a source of the most intensive dynamic load due to a rather wide spread of ranges in which the parameters that cause soil vibrations vary ${ }^{7}$. The scope of instrumental examinations and measurements depends on a vibration source category.

To estimate and ensure serviceability of buildings one shall forecast their life times and frequency of their scheduled repairs or overhauls. The standard service life values for structures are averaged, estimated and related to physical deterioration of materials values. The actual service life is affected by actual operating conditions. To establish changes in absolute or relative parameters, which are developed dynamically and affect the serviceability of buildings and structures, or effects of these parameters on construction projects they shall be recorded with the use of instrumental methods. Therefore the issue of determination of an optimal scope of instrumental examinations during construction and operation of buildings and structures is important.

\section{Algorithm of determination of an optimal scope of instrumental examinations subject to the vulnerability criterion}

Duration of the life cycle of buildings depends on timely accounting of risks of damages and forecasting of deterioration of building operating conditions under effects of external (natural or man-caused) and internal (construction or operational) risks. When the risks of damages are estimated a possible intensification of dangers, capacity and remoteness of a threat source, operating conditions of the building and vulnerability conditions

\footnotetext{
${ }^{6}$ VSN 358-76 Instructions on pile driving near buildings and structures. - M. : TsBNTI, 1976.

7 Dudkin E.S. Dynamic effects of municipal transport movement on buildings and structures / E.S. Dudkin // Polzunov Bulletin. 2007. - No. 1-2. - P. 30-32.
} 
shall be accounted for. In addition, the vulnerability of the building shall be estimated $^{8,9}$.

It has been proposed to consider the vulnerability as a building property to lose serviceability due to a possible damage of the building under effects of negative factors. A degree of vulnerability depends on a totality of conditions of the building, its soil base and surrounding territory. To make a decision on expediency and scope of examinations a classification of building vulnerabilities has been proposed (low, medium and high classes):

- low vulnerability

- low vulnerability

$$
k_{y \sigma} \leq 0,33 \cdot k_{y \max }=0,33,
$$

where $k_{y \max }=1,0$ is maximum possible value of the factor of vulnerability,

- medium vulnerability

$$
0,33>k_{y \sigma}>0,67
$$

- high vulnerability

$$
k_{y \sigma} \geq 0,67,
$$

$k_{y \sigma}$ may take values that exceed 1,0 when coefficients of threat significance or degrees of compliance are taken into account.

A decision on the necessity of examinations, their scope and periodicity are made on the basis of the results obtained during determination of the factors of vulnerability:

- at the low vulnerability of building the scope of examinations is usual i.e. taking into account the low probability of occurrence of damages the instrumental examinations are not necessary and visual examinations will be sufficient;

- at the medium vulnerability the scope of examinations is expanded i.e. taking into account the medium probability of occurrence of damages in

\footnotetext{
${ }^{8}$ Methodic recommendations for estimation of risk and damage at underflooding of territories. - M., 2001.

${ }^{9}$ Mikhailenko V.M., Hryhorovskyi P.Ye., Models and methods of information system for diagnostics of operating conditions of construction projects / V.M. Mikhailenko, I.V. Rusan, P.Ye. Hryhorovskyi, O.O. Terentiev, A.T. Sviderskiy, Ye.V. Horbatiuk. - K. : TsP «Komprynt». - 2018.
} 
addition to the visual inspections the periodic instrumental examinations shall be carried out;

- at the high vulnerability the scope of examinations is special i.e. taking into account the high probability of occurrence of damages, in addition to the necessity of the expanded scope of examinations the automated monitoring shall be carried out.

To determine the scope of instrumental examinations during operation of buildings the following algorithms shall be developed: estimation of risks of damages (determination of the vulnerability) of buildings with regard to threats; selection of methods and measures for inspection of operating conditions of buildings, checked parameters and periodicity of inspections; arrangement of measurements subject to the level of building vulnerability; determination of possible losses due to untimely detection of damages. The algorithm of determination of vulnerability is presented in Fig. 1.

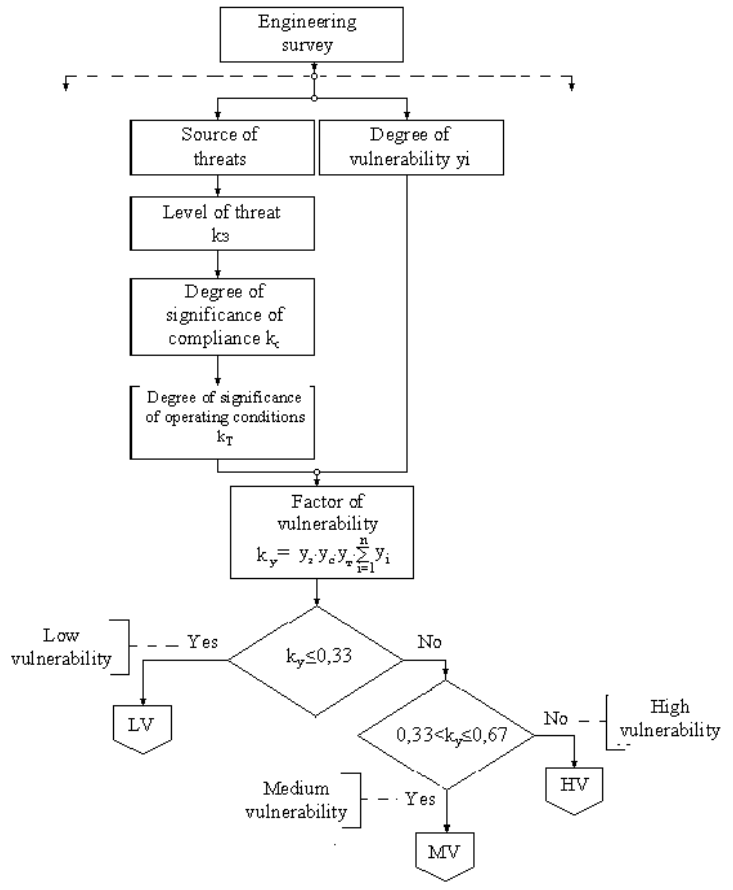

Fig. 1. Algorithm of taking account of risks of damages (determination of building vulnerability) 
- During the stage of designing threats for new and/or existing buildings as well as buildings located in the area affected by the new construction are determined on the basis of the engineering surveys. These findings shall be the basis for making a decision on a scope of controls and their operating conditions and the territory (see the figure). The algorithm of selection of control methods and measures, parameters and time intervals is depend on risks of damages, vulnerability of buildings and a territory of development (Fig. 2).

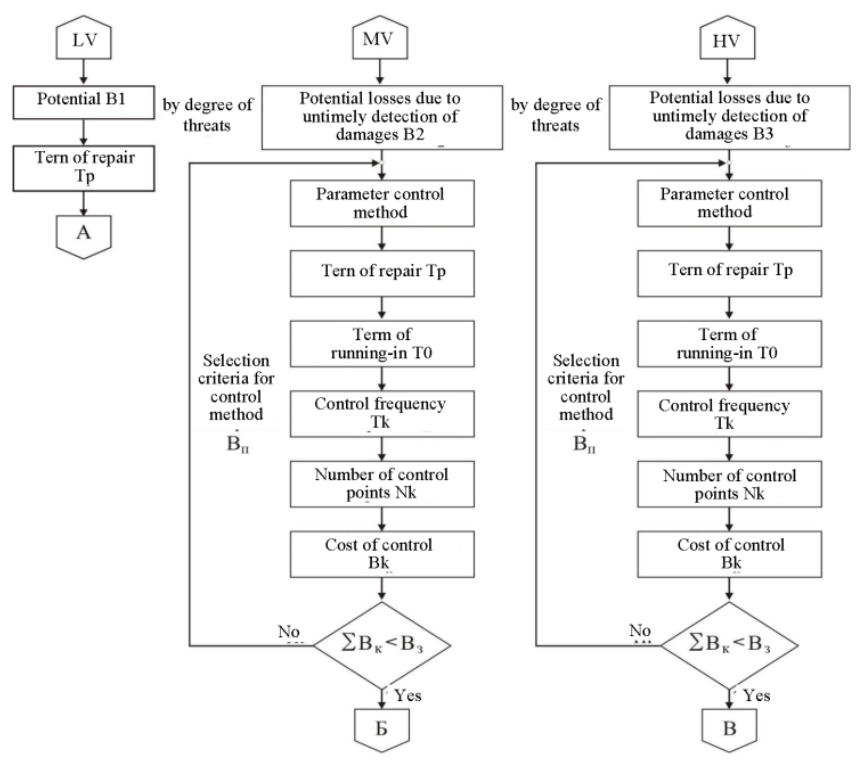

Fig. 2. Algorithm of selection of a method for examinations of building damages subject to a level of costs of potential losses (B1 - low, B2 - medium, B3 - high) for control versions:

$$
\text { (A-low, } \mathrm{B} \text { - medium, B - high) }
$$

In a case of low vulnerability (LV) control measures are not taken. Scheduled visual inspections and regular repairs are carried out. The frequency of repairs of the building is determined on the basis of its life cycle duration and predictable det $\epsilon$ Nion. In cases of medium and high vulnerability (MV, HV) the economic losses due to damages in the building are estimated before the selection of control methods. Costs of the control measures for variants A, Б, B against the potential $\mathrm{Y}$; are estimated, the frequency of measures and other technical and organizational indices are 
determined. The algorithms of measurement work during operation of buildings for variants A, Б, B are presented in Figs. 3-4.

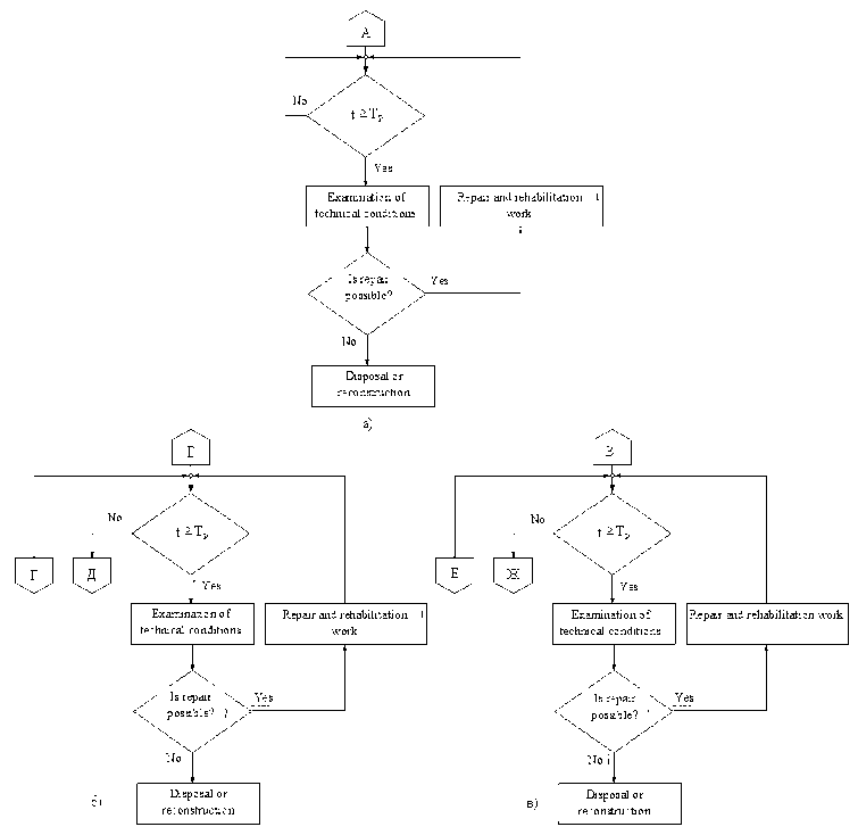

Fig. 3. shows the algorithm of arrangement of measurement work in the cases of low, medium or high vulnerabilities

Fig. 3. Algorithm of arrangement of measurement work during operation of buildings subject to design (A) values of listed factors and frequency of measurements, their changes (Б) according to variants $Д$ and $\Gamma$; changes (B) according to variants $\mathrm{E}$ and $Ж$ subject to a degree of object vulnerability

For variant A operations are carried out in a usual mode. If the term of operation has run up to the design term of repair $\left(T_{p}\right)$ examinations are carried out and their results are taken into account when a decision on a scope and composition of repairs is made. After completion of the repair work the building is continued to be under operation or, in a case when the serviceability has not been restored a decision on rehabilitation or disposal of the building is made. For medium or high vulnerability the building is operated in the same manner as for low vulnerability subject to possible changes in the frequency of measurements or the number of controlled 
parameters for higher degrees of vulnerability. The algorithm of such work is shown in Fig. 4.

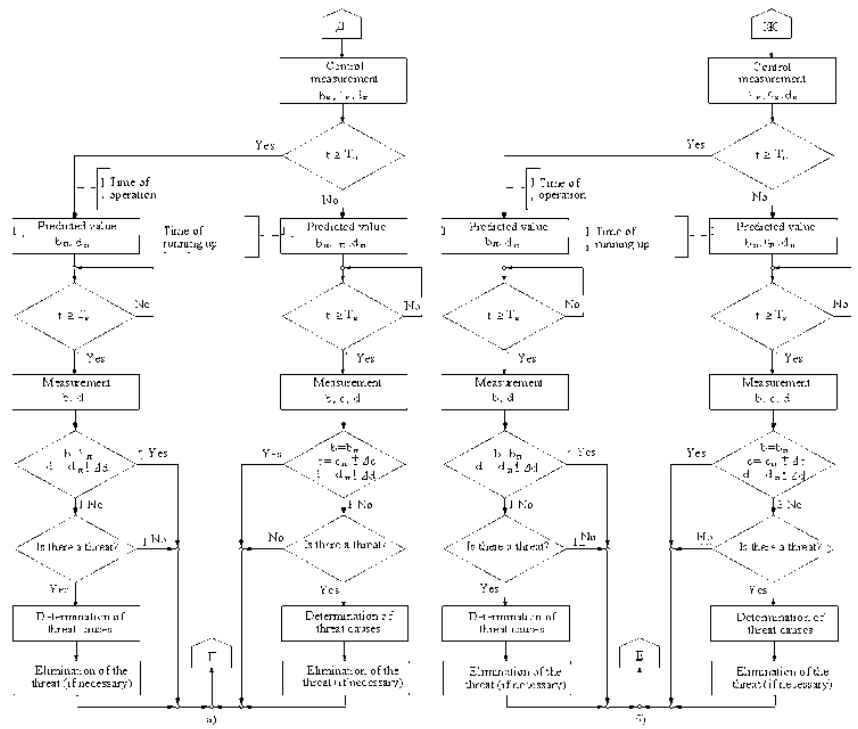

Fig. 4. Algorithm of arrangement of measurement work subject

to the object conditions under medium and high vulnerability (changes in the list of factors according variant Д and the frequency of measurements according variant $\Gamma$ )

Under medium vulnerability (variant Б) in the period of time before the term of established frequency of repair work $\left(T_{p}\right)$ the measurements are carried out (for the list of factors by variant Д) with the frequency (by variant $\Gamma$ ) established in designing. Under high vulnerability (variant B) the number of parameters may be more (variant $Ж$ ) and the frequency may be less (variant E). For automated systems the measurements will be carried out permanently.

The control operations begin with the measurement of parameters' initial values which will be used for forecasting. From the start of the building operation the processes of running up and initial subsidence begin. The term of initial subsidence $\left(T_{o}\right)$ is determined by soil properties. When the term $\left(T_{o}\right)$ is over the parameters specified in the project are checked and their predicted values are determined. When the control term $\left(T_{k}\right)$ is over, the building's parameters are compared with the predicted ones. If they are in 
accordance the control operations shall be continued as usual. If the parameters are at variance with the predicted ones causes of deviations shall be analyzed and preventive measures shall be taken. When the term $\left(T_{o}\right)$ is not over, in addition to the planned parameters the building's initial subsidence values shall be checked.

Losses due to untimely detection of damages are determined by estimation of risks for some territories, buildings or structures that are similar by their natural and man-caused conditions as well as geological threats sequentially. For them a warning period (the time interval for which the estimation of potential negative consequences is made) that equals the building service life without any repairs is established.

Risk of economic losses due to damages of building $B_{3}$ is established with due account of a negative effect of threat ${ }^{10}$ by formula

$$
\mathrm{B}_{3}=\mathrm{P}_{3} \cdot \mathrm{V}_{3} \cdot \mathrm{B}_{6} \cdot \mathrm{T}_{\text {заг }},
$$

where $P_{3}=\frac{T_{\text {zar }}}{T_{c}}$ is the probability of damages for the service life time;

$\mathrm{T}_{3 a r}=\mathrm{T}_{\mathrm{p}}$ is the time of probable damages (the term of next repair and restoration work);

$\mathrm{T}_{\mathrm{c}}$ is the building's service life;

$\mathrm{V}_{3}$ is the building's economic vulnerability to damages, 1/year, it shall be determined in accordance with ${ }^{9}$ subject to relations (1-3);

$\mathrm{B}_{\sigma}$ is the building cost at the beginning of the process.In estimating the economic losses for buildings which are historical landmarks the cost of objects in formula (4) is recommended to be replaced by the cost of their rehabilitation. The risk of general economic losses due to damages of buildings and structures is determined as a sum of losses due to individual risks. In estimating risks at the stage of designing (for example for underflooding) the economic vulnerability may be determined according to ${ }^{9}$ subject to relationships (4-5) and Tables 1-2.

Table 1

Mean values of economic vulnerability for underflooding processes

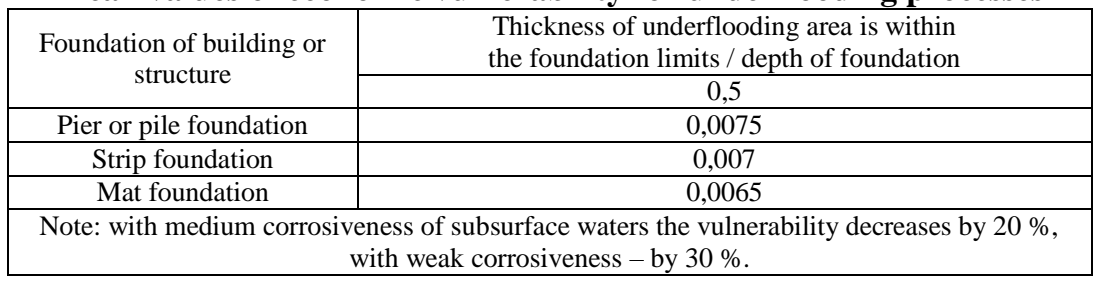

${ }^{10}$ Recommendations on estimation of geological risks in the territory of the city of Moscow 
Mean values of economic vulnerability for subsidence of bases due to geological threats

\begin{tabular}{|c|c|c|}
\hline \multirow{2}{*}{ Buildings and structures } & \multirow{2}{*}{ Subsidence, $\mathrm{cm}$} & Subsidence area / total area of foundations, $\mathrm{m}^{2}$ \\
\cline { 3 - 3 } & $20 \div 50$ & 0,5 \\
\hline Frame & $20 \div 50$ & 0,30 \\
\hline Frameless reinforced & $30 \div 50$ & 0,14 \\
\hline Frameless plain & $30 \div 50$ & 0,05 \\
\hline Monolithic & 0,005 \\
\hline
\end{tabular}

The economic losses are determined with due account of vulnerability $\mathrm{k}_{\mathrm{y}}$ and the physical deterioration of building

$$
\mathrm{B}_{3}=\mathrm{k}_{\mathrm{y}} \cdot\left(1-\mathrm{k}_{\text {зн }}\right) \cdot \sum_{\mathrm{i}=1}^{\mathrm{n}} \mathrm{B}_{3 \mathrm{i}},
$$

where $\mathrm{B}_{3 \mathrm{i}}$ is the economical losses due to the $\mathrm{i}^{\text {th }}$ threat;

$\mathrm{n}$ is the number of threat factors;

$$
\mathrm{k}_{\text {зн }}=\sum_{\mathrm{i}=1}^{\mathrm{m}} \mathrm{k}_{\text {зні }} \cdot \mathrm{k}_{\text {вві }} ;
$$

$\mathrm{k}_{\text {зні }} \quad$ is physical deterioration of the $\mathrm{i}^{\text {th }}$ structure;

$\mathrm{k}_{\text {вві }} \quad$ is the coefficient of restored cost of the $i^{\text {th }}$ structure;

$\mathrm{m}-$ is the number of damaged structures in the building.

During examinations just after construction work $\mathrm{k}_{\text {нН }}=1$.

\section{Principles of determination}

\section{of a scope of examinations for deformations}

The principles of determination of a scope of examinations for deformations are presented with due account of the vulnerability criterion ${ }^{11}$. The parameters that affect the degree of vulnerability ${ }^{4,12,13}$ are as follows: type of underground structure, degree of building deterioration; type of foundation, coefficient of slope stability, lithologic rock units, slope steepness, groundwater conditions. Underfloodings and vibrations are causes

${ }^{11}$ Tishin V.G. Fuzzy logic presentation of estimation of vulnerability of buildings and structures during designing and long operation under conditions of uncertainty / V.G. Tishin // Proceedings of Samara Center of the Russian Academy of Sciences. - 2011. - V. 13. - No. 4. P. 1034-1040.

${ }^{12}$ GOST R 22.8.09-2014. Safety in emergencies. Requirements to safety, risk, and damage levels estimation at underflooding of urban and industrial areas. - M. : Standartinform, 2015.

${ }^{13}$ Ruban N.N. Estimation of parameters of dynamic impacts from transport sources under conditions of the city of Dnepropetrovsk / Prospects of development of construction technologies : conf. publ. - 2007. - P. 86-95. 
of the increased probability of failures. When the parameters act jointly the numerical estimation of the degree of their joint influence is rather difficult as there is no any established criterion. Therefore this estimation of the building vulnerability has been carried out by the method of expert polling ${ }^{14}$. The values of the maximum possible degree of vulnerability to the factors of natural nature are shown in Table 3 .

Table 3

\section{Degree of building vulnerability}

\section{with due account of the factors of natural nature}

\begin{tabular}{|c|c|c|c|c|}
\hline Parameter & $\begin{array}{c}\text { Coefficient of } \\
\text { slope stability }\end{array}$ & $\begin{array}{c}\text { Lithologic rock } \\
\text { units }\end{array}$ & $\begin{array}{c}\text { Slope } \\
\text { steepness }\end{array}$ & $\begin{array}{c}\text { Groundwater } \\
\text { conditions }\end{array}$ \\
\hline Parameter code & $\mathrm{y} 1$ & $\mathrm{y} 2$ & $\mathrm{y} 3$ & $\mathrm{y} 4$ \\
\hline $\begin{array}{c}\text { Degree of } \\
\text { vulnerability }\end{array}$ & 0,30 & 0,21 & 0,31 & 0,18 \\
\hline
\end{tabular}

Parameters of building bases that affect their degree of vulnerability ${ }^{8}$ are shown in Table 4.

Table 4

Parameters of building bases

\begin{tabular}{|c|c|c|}
\hline Code & Designation of parameter & $\begin{array}{c}\text { Degree of } \\
\text { vulnerability }\end{array}$ \\
\hline \multirow{4}{*}{$\mathrm{y} 1$} & \multicolumn{2}{|l|}{ Coefficient of stability } \\
\hline & 1,25 & 0,10 \\
\hline & 1,20 & 0,20 \\
\hline & $>1,15$ & 0,30 \\
\hline \multirow{4}{*}{ y2 } & \multicolumn{2}{|l|}{ Lithologic rock units } \\
\hline & Silicified claystones, siltstones, sandstones & 0,07 \\
\hline & Marls with layers of marly siltstones, claystones, sandstones & 0,14 \\
\hline & $\begin{array}{l}\text { Marls with layers of sandstones, calciferous claystones with layers of } \\
\text { sandstones }\end{array}$ & 0,21 \\
\hline \multirow{4}{*}{$\mathrm{y} 3$} & \multicolumn{2}{|l|}{ Slope steepness, degr. } \\
\hline & $0 \div 2$ & 0,10 \\
\hline & $2 \div 10$ & 0,21 \\
\hline & $10 \div 15$ and more & 0,31 \\
\hline \multirow{4}{*}{ y4 } & \multicolumn{2}{|l|}{ Groundwater conditions } \\
\hline & Absence of underground water & 0,06 \\
\hline & Sporadic expansion of underground water & 0,12 \\
\hline & Constant level of underground water & 0,18 \\
\hline
\end{tabular}

To take account of effects of underfloodings and vibrations in a draft plan of protective measures Table 5 shows data that characterize parameters of underflooding due to networks of water utilities ${ }^{12}$.

\footnotetext{
${ }^{14}$ Litvak B.G. Expert estimation and decision making / B.G. Litvak. - M. : Patent, 1996
} 
Characteristics of water utilities

\begin{tabular}{|c|c|c|c|}
\hline \multirow{2}{*}{$\begin{array}{c}\text { Parameter of water utilities } \\
\text { and water basins } \\
\text { (coefficient of significance), k3H }\end{array}$} & \multicolumn{3}{|c|}{$\begin{array}{c}\text { Coefficient of significance, } \\
\text { (value of parameter) }\end{array}$} \\
\cline { 2 - 4 } & high & medium & low \\
\hline Density of water utilities, $\mathrm{m} / \mathrm{ha}\left(k_{u}\right)$ & $\begin{array}{c}\text { more than } 500 \\
(1,2)\end{array}$ & $\begin{array}{c}400 \div 500 \\
(1,1)\end{array}$ & $\begin{array}{c}\text { less than } 400 \\
(1,0)\end{array}$ \\
\hline $\begin{array}{c}\text { Degree of deterioration of water utilities, } \\
\%,\left(k_{3}\right)\end{array}$ & $\begin{array}{c}\text { more than } 50 \\
(1,2)\end{array}$ & $\begin{array}{c}35 \div 50 \\
(1,1)\end{array}$ & $\begin{array}{c}\text { less than } 35 \\
(1,0)\end{array}$ \\
\hline $\begin{array}{c}\text { Distance from a natural source of } \\
\text { underflooding, } \mathrm{m},\left(k_{b}\right)\end{array}$ & $\begin{array}{c}\text { less than } 50 \\
(1,2)\end{array}$ & $\begin{array}{c}50 \div 200 \\
(1,1)\end{array}$ & $\begin{array}{c}\text { more than } 200 \\
(1,0)\end{array}$ \\
\hline
\end{tabular}

Effects of degrees of building compliance on factors of vulnerability are shown in Table 6.

Table 6

Effects of degrees of compliance on factors of
\begin{tabular}{|c|c|}
\hline Characteristic & Value kc \\
\hline degree of compliance CC1 & 0,9 \\
\hline degree of compliance CC2 & 1,0 \\
\hline degree of compliance CC 3 & 1,1 \\
\hline
\end{tabular}

Table 7 shows data that characterize sources of vibrations and coefficients of significance of these parameters with due account of the results ${ }^{13}$.

Table 7

Parameters of vibration sources

\begin{tabular}{|c|c|c|c|}
\hline \multirow{2}{*}{$\begin{array}{c}\text { Parameter of vibration sources } \\
\text { (coefficient of significance), k3H }\end{array}$} & \multicolumn{3}{|c|}{$\begin{array}{c}\text { Degree of significance, } \\
\text { (parameter value) }\end{array}$} \\
\cline { 2 - 4 } & high & medium & low \\
\hline Distance from a railway line, $\mathrm{m}\left(k_{b 3}\right)$ & $\begin{array}{c}\text { less than } 5 \\
(1,2)\end{array}$ & $\begin{array}{c}5 \div 200 \\
(1,1)\end{array}$ & $\begin{array}{c}\text { more than } 200 \\
(1,0)\end{array}$ \\
\hline Distance from a tramway line, $\mathrm{m}\left(k_{b 3}\right)$ & $\begin{array}{c}\text { less than } 5 \\
(1,2)\end{array}$ & $\begin{array}{c}5 \div 200 \\
(1,1)\end{array}$ & $\begin{array}{c}\text { more than } 200 \\
(1,0)\end{array}$ \\
\hline Distance from a Metro line, $\mathrm{m}\left(k_{b u}\right)$ & $\begin{array}{c}\text { less than } 5 \\
(1,2)\end{array}$ & $\begin{array}{c}5 \div 100 \\
(1,1)\end{array}$ & $\begin{array}{c}\text { more than } 100 \\
(1,0)\end{array}$ \\
\hline Distance from a highway, $\mathrm{m}\left(k_{b a}\right)$ & $\begin{array}{c}\text { less than } 5 \\
(1,2)\end{array}$ & $\begin{array}{c}5 \div 50 \\
(1,1)\end{array}$ & $\begin{array}{c}\text { more than } 50 \\
(1,0)\end{array}$ \\
\hline
\end{tabular}

The factor of building vulnerability to slides is calculated according to relationship (7) with the use of the data shown in Tables 4-7.

For further analysis and application the total vulnerability is divided into three degrees: high $\left(y_{i}\right)$, medium $\left(0,67 \cdot y_{\mathrm{i}}\right)$ and low $\left(0,33 \cdot \mathrm{y}_{\mathrm{i}}\right)$. For estimation 
of the total vulnerability the factor of vulnerability $k_{y}$, which equals a sum of the building vulnerabilities to some parameters, has been used

$$
\mathrm{k}_{\mathrm{y}}=\sum_{\mathrm{i}=1}^{\mathrm{n}} \mathrm{y}_{\mathrm{i}} \text {, at } 0 \leq \mathrm{k}_{\mathrm{y}} \leq 1
$$

where $y_{i}$ is the numerical value of vulnerability to the $i^{\text {th }}$ factor of influence;

$\mathrm{n}$ is the number of factors of influence on the object.

Probability of damages depends on not only the building vulnerability but also the characteristics of the threat source. The factors of influence may be separately estimated in every particular case as a coefficient of significance $k_{3}$ for the resulting factor of vulnerability.

To take account of a degree of building compliance let's adopt a value of the coefficient of influence on vulnerability according to Table 6 . Then the coefficient of building vulnerability $k_{\mathrm{y} \sigma}$ to a particular factor may be determined as

$$
\mathrm{k}_{\mathrm{y} \sigma}=\mathrm{k}_{\mathrm{c}} \cdot \mathrm{k}_{3} \cdot \mathrm{k}_{\mathrm{y}},
$$

where $\mathrm{k}_{\mathrm{ci}}$ is the coefficient of influence of a degree of building compliance;

$\mathrm{k}_{3}$ is the coefficient of significance (power) of a threat source;

$\mathrm{k}_{\mathrm{y}}$ is the coefficient of vulnerability that is taken according to (8).

When there are a number of threats they shall be considered separately and a maximum or total value $\mathrm{k}_{3}=\mathrm{k}_{3}^{\max }$ shall be taken for estimation.

To make a decision on a necessity of performing examinations and their scope let's determine a class of building vulnerability to a particular risk factor according to relationships (1-3).

The coefficient $\mathrm{k}_{\mathrm{y} \sigma}$ can take values that exceed 1,0 when a coefficient of threat significance, a degree of compliance etc. are taken into account. The further development of processes may be predicted on the basis of the examination results. The frequency of checks is determined by a maximum rate of changes in geometrical parameters of buildings, structures and development areas (deformations, subsidences, slides) subject to ratios of costs of measurements and 


\section{Selection of a system and scope of instrumental examinations of underfloodings}

Negative consequences of underflooding processes are subsidences and depressions in the earth surface due to soil wetting and compacting when the level of ground water rises. As a result the corrosive destruction of foundations and lower parts of surface structures occurs and increases the rate of deterioration and deformation of a building as a whole and leads to flooding of basements, lift shafts, underground structures and utilities of shallow locations. Risks of damages are estimated on the basis of the data of engineering surveys. In addition to estimation of potential causes of damages the estimation of risks shall include the estimates of vulnerability of buildings and nearby areas ${ }^{8}$. The method uses the known criteria of estimation of underflooding effects on building structures with the use of the factor of vulnerability that characterizes a degree of influence on buildings and structures. On the basis of the factor of vulnerability a degree of underflooding threat for buildings may be estimated and a decision on necessity of instrumental examinations or permanent automated monitoring can be made.

Input data for selection of a measurement system and designing a procedure of measurement work under operation are as follows: design solutions and construction materials which affect the vulnerability of a building to underflooding; soil features to change its characteristics after being underflooded; sources of potential underflooding whose presence is a threat to the building; the building's operating conditions whose deterioration increases its vulnerability.

An attempt of quantitative estimation of the degree of risks' negative effects demonstrates a need for characterization of an emerged threat. For this purpose the method of expert assessment has been applied. The method has been described in the previous paragraph. The following factors have been ranked as the highest: a degree of building deterioration, foundation type, bearing capability of soils, level of subsurface water (Table 8).

Table 8

Degree of building vulnerability under underflooding

\begin{tabular}{|c|c|c|c|c|}
\hline Parameter & $\begin{array}{c}\text { Degree of building } \\
\text { deterioration }\end{array}$ & $\begin{array}{c}\text { Type of } \\
\text { foundation }\end{array}$ & $\begin{array}{c}\text { Bearing } \\
\text { capability of } \\
\text { soils }\end{array}$ & $\begin{array}{c}\text { Level of } \\
\text { subsurface } \\
\text { water }\end{array}$ \\
\hline Parameter code & $\mathrm{y} 1$ & $\mathrm{y} 2$ & $\mathrm{y} 3$ & $\mathrm{y} 4$ \\
\hline Degree of vulnerability & 0,22 & 0,17 & 0,33 & 0,28 \\
\hline
\end{tabular}


Tables 9-10 show buildings and bases parameters that affect a degree of vulnerability under underflooding. The degree of low vulnerability is defined as $0,67 \cdot y_{i}$ and $0,33 \cdot y_{i}$ of the maximum vulnerability.

To estimate the building vulnerability to parameters that threaten with damages the factor of building vulnerability $\mathrm{k}_{\mathrm{y}}$ represented by a sum of the factors of vulnerability to individual parameters is used

$$
\mathrm{k}_{\mathrm{y}}=\sum_{\mathrm{i}=1}^{\mathrm{n}} \mathrm{y}_{\mathrm{i}} \text {, at } 0 \leq \mathrm{k}_{\mathrm{y}} \leq 1
$$

\section{Table 9}

Parameters of buildings

\begin{tabular}{|l|c|c|}
\hline Code & Degree of vulnerability & Designation of parameter \\
\hline \multirow{3}{*}{ y1 } & \multicolumn{2}{|c|}{ Degree of building deterioration } \\
\cline { 2 - 3 } & 0,07 & less than $15 \%$ \\
\cline { 2 - 3 } & 0,15 & $15 \div 50 \%$ \\
\hline \multirow{3}{*}{ y2 } & 0,22 & more than $50 \%$ \\
\cline { 2 - 3 } & \multicolumn{2}{|c|}{ Type of foundation } \\
\cline { 2 - 3 } & 0,06 & pile \\
\cline { 2 - 3 } & 0,11 & mat \\
\hline
\end{tabular}

Probability of damages depends on not only the building vulnerability but also the properties of the source of threat. Such properties may be a distance of the building from the source or a parameter that characterizes the threat source's power. These factors may be estimated separately as a coefficient of significance $k_{3}$ for the resulting factor of vulnerability.

Table 10

\section{Parameters of soils}

\begin{tabular}{|c|c|c|}
\hline Code & Degree of vulnerability & Designation of parameter \\
\hline \multirow{4}{*}{ y3 } & \multicolumn{2}{|c|}{ Decrease in soil bearing capability } \\
\cline { 2 - 3 } & 0,11 & $<10 \%$ \\
\cline { 2 - 3 } & 0,22 & $10 \div 30 \%$ \\
\hline \multirow{4}{*}{ y4 } & 0,33 & $>30 \%$ \\
\cline { 2 - 3 } & \multicolumn{2}{|c|}{ Depth of subsurface water level with reference to earth surface, $\mathrm{m}$} \\
\cline { 2 - 3 } & 0,09 & $>2$ \\
\cline { 2 - 3 } & 0,19 & $1 \div 2$ \\
\hline
\end{tabular}

To take account of a degree of building compliance the coefficient of influence on vulnerability is adopted according to Table 11 . 
Table 11

Effect of degrees of building compliance on factors of vulnerability

\begin{tabular}{|l|c|c|}
\hline Designation & Value & Characteristic \\
\hline \multirow{3}{*}{$\mathrm{kc}$} & 0,9 & degree of compliance CC1 \\
\cline { 2 - 3 } & 1,0 & degree of compliance CC2 \\
\cline { 2 - 3 } & 1,1 & degree of compliance CC3 \\
\hline
\end{tabular}

In such a case a factor of vulnerability $\mathrm{k}_{\mathrm{y} 6}$ to a specific parameter of influence may be determined by relationship (7) where $\mathrm{k}_{\mathrm{y}}$ is a factor of vulnerability that is determined by relationship (8).

When a number of threats exist they shall be examined individually and the maximum value $k_{3}=k_{3}^{\max }$ shall be taken. The data on parameters of underflooding sources due to water utilities networks ${ }^{15}$ are shown in Table 12. The factor of building vulnerability to underflooding is calculated by formula (8) with the use of values shown in Tables 9-12.

A decision on a need for examinations and their scope is made with due account of relationships (1-3).

Table 12

Characteristics of water utilities

\begin{tabular}{|c|c|c|c|}
\hline \multirow{2}{*}{$\begin{array}{c}\text { Parameter of water utilities and water basins } \\
\text { (coefficient of significance), k3H }\end{array}$} & \multicolumn{3}{|c|}{$\begin{array}{c}\text { Coefficient of significance, } \\
\text { (value of parameter) }\end{array}$} \\
\cline { 2 - 4 } high & medium & low \\
\hline Density of water utilities, $\mathrm{m} / \mathrm{ha}\left(\mathrm{k}_{\mathrm{II}}\right)$ & $\begin{array}{c}\text { more than } 500 \\
(1,2)\end{array}$ & $\begin{array}{c}400 \div 500 \\
(1,1)\end{array}$ & $\begin{array}{c}\text { less than } 400 \\
(1,0)\end{array}$ \\
\hline Degree of deterioration of water utilities, $\%,\left(\mathrm{k}_{3}\right)$ & $\begin{array}{c}\text { more than } 50 \\
(1,2)\end{array}$ & $\begin{array}{c}35 \div 50 \\
(1,1)\end{array}$ & $\begin{array}{c}\text { less than } 35 \\
(1,0)\end{array}$ \\
\hline Distance from a natural source of underflooding, \\
$\mathrm{m},\left(\mathrm{k}_{\mathrm{B}}\right)$ & $\begin{array}{c}\text { less than } 50 \\
(1,2)\end{array}$ & $\begin{array}{c}50 \div 200 \\
(1,1)\end{array}$ & $\begin{array}{c}\text { more than } \\
200 \\
(1,0)\end{array}$ \\
\hline
\end{tabular}

\section{Selection of a system and scope of instrumental examinations of vibrations}

The method takes data on vibrations, their effects on buildings and factors of vulnerability into account. Input data for designing solutions for instrumental measurements are as follows: design solutions and construction materials which affect the vulnerability of a building to vibrations; soil capabilities to transfer vibrations to building structures; sources of vibrations

${ }^{15}$ Hryhorovskiy P.Ye. Selection of optimal methods for monitoring of operating conditions of building structures with the use of utility functions / P.Ye. Hryhorovskiy, N.P. Chukanova // New technologies in construction : coll. of sci. and tech. articles - K. : Publ. «Lira-K», 2014. Issue 27-28. - P. 21-24 
which threaten to disturb operating conditions of buildings; the building's operating conditions whose deterioration increases building vulnerability.

The main sources of man-caused vibrations in urban development areas are rail transport lines (Metro, tram lines and railway tracks). The range of vibration frequencies at various points of building depends on a source of generation, properties of soil, through which the generated vibrations are transmitted to structures, and transfer properties of structures ${ }^{4,8}$. The level of vibrations depends on excitation frequency and may be varied from units to some hundreds of millimeters per second.

Threats of damages may be disclosed by indirect methods such as periodic observations of vibration frequencies and levels, examinations of building operating conditions, subsidences and inclinations. External manifestations of such threats at the initial stages may be unnoticeable, therefore they are considered unsafe and owing to difficulties of their timely detection they can cause significant damages.

The vulnerability to vibrations is characterized by a limit value of velocity $\mathrm{v}_{\mathrm{rp}}$, whish is determined for a vertical component of the peak value of velocity.

$$
\mathrm{V}_{\mathrm{rp}}=\mathrm{v}_{0} \cdot \mathrm{F}_{\mathrm{g}} \cdot \mathrm{F}_{\mathrm{b}},
$$

where $\mathrm{v}_{0}$ is the reference value of velocity, $20 \mathrm{~mm} / \mathrm{s}$;

$F_{g}$ is the correction for the type of soil at the site of constructed structure (Table 13);

$F_{b}$ is the correction for the type and design of building and foundation.

Table 13

Correction for type of soil $\mathbf{F}_{\mathrm{g}}$

\begin{tabular}{|c|c|}
\hline Characteristic of soil & $\mathrm{F}_{\mathrm{g}}$ \\
\hline Very soft soil, soft clay & 0,5 \\
\hline Clay, muddy soil with high content of moisture & 0,8 \\
\hline Sand, crushed stone, muddy soil & 1,0 \\
\hline Firm boulder clay, packed filling with crushed stone & 1,8 \\
\hline
\end{tabular}

The correction for a type of building $F_{\mathrm{B}}$ depends on a type and design of structure, construction material and a type of foundation; it is calculated by formula

$$
\mathrm{F}_{\mathrm{b}}=\mathrm{k}_{\mathrm{b}} \cdot \mathrm{k}_{\mathrm{m}} \cdot \mathrm{k}_{\mathrm{f}},
$$

where $\mathrm{k}_{\mathrm{b}}$ is the correction for a type and design of structure; 
$\mathrm{k}_{\mathrm{m}}$ is the correction for material of structure;

$\mathrm{k}_{\mathrm{f}}$ is the correction for a type of foundation (Tables 14-16).

A degree of vibration effect on vulnerability of buildings has been estimated as a function of the peak value of vibration velocity ${ }^{4}$ with the use of the method of expert estimation (Table 17).

Table 14

Correction for type and design of structure $k_{b}$

\begin{tabular}{|c|c|}
\hline Type of structure & $\mathrm{k}_{\mathrm{b}}$ \\
\hline Large structure (bridge, trestle) & 1,70 \\
\hline Office building, production building & 1,20 \\
\hline Residential building of general design & 1,00 \\
\hline $\begin{array}{c}\text { Building that is highly sensitive to vibrations (high-rise building, structure with } \\
\text { lengthy flights) }\end{array}$ & 0,65 \\
\hline Historic or destroyed buildings & 0,50 \\
\hline
\end{tabular}

Table 15

Correction for material of structure $k_{m}$

\begin{tabular}{|c|c|}
\hline Basic material & $\mathrm{k}_{\mathrm{m}}$ \\
\hline Reinforced concrete, steel, wood & 1,20 \\
\hline $\begin{array}{c}\text { Plain concrete, porous concrete block, brickwork, light perlite concrete and other } \\
\text { similar materials }\end{array}$ & 1,00 \\
\hline Porous autoclaved concrete block and other similar materials & 0,75 \\
\hline
\end{tabular}

Table 16

Correction for type of foundation $\mathbf{k}_{\mathbf{f}}$

\begin{tabular}{|c|c|}
\hline Type of foundation & $\mathrm{k}_{\mathrm{f}}$ \\
\hline Bank, shearwall, foundation post & 0,7 \\
\hline Spread foundation & 0,8 \\
\hline Floating pile & 0,9 \\
\hline Column pile & 1,0 \\
\hline
\end{tabular}

Estimation of factors of influence may be designated as a coefficient of significance $\mathrm{k}_{3 \mathrm{i}}$ that characterizes the effect of vibrations on the vulnerability to the $i^{\text {th }}$ source of vibrations.

Table 17

Factor of vulnerability to vibrations

\begin{tabular}{|c|c|c|}
\hline \multirow{2}{*}{ Code } & $\begin{array}{c}\text { Vertical component of the peak value } \\
\text { of vibration velocity, }\end{array}$ & Factor of vulnerability \\
\hline \multirow{3}{*}{$\mathrm{k}_{\mathrm{y}}$} & $\mathrm{v}<0,1 \cdot \mathrm{v}_{\mathrm{rp}}$ & 0,33 \\
\cline { 2 - 3 } & $0,1 \cdot \mathrm{v}_{\mathrm{rp}}<\mathrm{v}<0,8 \mathrm{v}_{\mathrm{rp}}$ & 0,67 \\
\cline { 2 - 3 } & $\mathrm{v} \geq 0,8 \cdot \mathrm{v}_{\mathrm{rp}}$ & 1,0 \\
\hline
\end{tabular}


To take account of a degree of building compliance in the factor of vulnerability $\left(\mathrm{k}_{\mathrm{y} \sigma}\right)$ let's take the coefficient of significance of the effect of degree of vulnerability $\left(\mathrm{k}_{\mathrm{c}}\right)$ according to Table 11 . Let's take the factor of building vulnerability $k_{y \sigma}$ to a specific parameter according to (7). If there are a number of threats the maximum (or total) value $k_{3}=k_{3 i}^{\max }$ is taken as an estimate of threat. The coefficients of significance have been determined by the expert polling. The factor of vulnerability to vibrations is calculated according to relationship (8) with the use of vibration velocity values and parameters of threats.

A decision on a need of examinations and their scope is made subject to relationships (1-3).

\section{Selection of a system and scope of instrumental examinations of slides}

Input data for selection of a system and designing a process of measurement work under presence of slide threats are as follows: stability of slopes and their steepness; conditions and geological composition of soil base; sources of underfloodings and vibrations that threaten with disruption of slope stability. Risks of damages are estimated on the basis of the data of the engineering surveys which have been designated for developing measures for reducing negative effects of geological processes, natural and man-caused emergencies. In addition to estimation of threats the estimation of risks of damages shall include the estimates of vulnerability of buildings and nearby areas.

The degree of building vulnerability depends on characteristics of the building as well as characteristics and conditions of the soil base. Parameters of buildings and development areas which affect the degree of vulnerability are as follows: type of underground structure, degree of building deterioration, type of foundation, coefficient of slope stability, lithologic rock units, slope steepness, groundwater conditions.

The expert polling has determined the maximum possible degree of vulnerability to slides (Table 18).

Table 18

Degree of building vulnerability to slides

\begin{tabular}{|c|c|c|c|c|}
\hline Parameter & $\begin{array}{c}\text { Coefficient of slope } \\
\text { stability }\end{array}$ & $\begin{array}{c}\text { Lithologic rock } \\
\text { units }\end{array}$ & $\begin{array}{c}\text { Slope } \\
\text { steepness }\end{array}$ & $\begin{array}{c}\text { Groundwater } \\
\text { conditions }\end{array}$ \\
\hline Parameter code & $\mathrm{y} 1$ & $\mathrm{y} 2$ & $\mathrm{y} 3$ & $\mathrm{y} 4$ \\
\hline Degree of vulnerability & 0,30 & 0,21 & 0,31 & 0,18 \\
\hline
\end{tabular}

Main parameters of buildings and bases which affect the degree of vulnerability to slides are shown in Table 19. For estimation of building 
vulnerability to factors that threaten with occurrence of slides the factor of building vulnerability $\mathrm{k}_{\mathrm{y}}$ has been used. This factor is a sum of degrees of vulnerability to individual factors according to (8).

To take account of the degree of building compliance let's adopt the value of the coefficient of influence on vulnerability according to Table 6 . The factor of building vulnerability $k_{y \sigma}$ to a particular risk factor may be determined by (7). If there are a number of threats they shall be examined separately and the maximum value $\mathrm{k}_{3}=\mathrm{k}_{3}^{\max }$ shall be taken as an estimate of threat.

Underfloodings and vibrations may be causes which increase probability of slides. At that one shall take into consideration that at the stage of designing all measures against landslides shall be provided. The data specified in ${ }^{16}$ characterize parameters of underflooding sources related to water utilities (Table 5) and parameters of vibration sources (Table 7). The factor of building vulnerability to slides is calculated according to (8) with the use of values shown in Tables 7, 12, 18, 19. A decision on a need of examinations and their scope is made subject to relationships (1-3).

Table 19

Parameters of slopes

\begin{tabular}{|c|c|c|}
\hline Code & Designation of parameter & $\begin{array}{c}\text { Degree of } \\
\text { vulnerability }\end{array}$ \\
\hline \multirow{4}{*}{ yl } & \multicolumn{2}{|l|}{ Coefficient of slope stability } \\
\hline & 1,25 & 0,10 \\
\hline & 1,20 & 0,20 \\
\hline & $>1,15$ & 0,30 \\
\hline \multirow{4}{*}{$y_{2}$} & \multicolumn{2}{|l|}{ Lithologic rock units } \\
\hline & Silicified claystones, siltstones, sandstones & 0,07 \\
\hline & Marls with layers of marly siltstones, claystones, sandstones & 0,14 \\
\hline & $\begin{array}{l}\text { Marls with layers of sandstones, calciferous claystones with layers } \\
\text { of sandstones }\end{array}$ & 0,21 \\
\hline \multirow{4}{*}{$y_{3}$} & \multicolumn{2}{|l|}{ Slope steepness, degr. } \\
\hline & $0 \div 2$ & 0,10 \\
\hline & $2 \div 10$ & 0,21 \\
\hline & $10 \div 15 \mathrm{i}$ and more & 0,31 \\
\hline \multirow{4}{*}{$y_{4}$} & \multicolumn{2}{|l|}{ Groundwater conditions } \\
\hline & Absence of underground water & 0,06 \\
\hline & Sporadic expansion of underground water & 0,12 \\
\hline & Constant level of underground water & 0,18 \\
\hline
\end{tabular}

${ }^{16}$ DBN V.1.1-25-2009. Protection against dangerous geological processes. Engineering protection of territories and structures against underflooding and flooding. - [Current version 2011-01-01]. - K. : Minregionbud of Ukraine, 2010 
Further development of slides may be forecasted on the basis of the results of examinations. The frequency of checks is determined by the maximum velocity of slides subject to the ratio of the costs of such checks and potential losses due to development of slide processes.

\section{CONCLUSIONS}

1. Potential losses due to untimely detection of damages are recommended to prevent by sequential estimations of risks of individual, similar to natural and man-caused conditions and geological threats for development areas with a term of warning (the time interval for which possible negative consequences are estimated) that is equal to the established service life of buildings and structures without any repair or rehabilitation work.

2. The method of determination of the optimal scope of instrumental examinations during operation of buildings and structures with due account of the criterion of vulnerability has been developed.

3. The main parameters of buildings and development areas that affect the degree of vulnerability are as follows: type of underground structure, degree of building deterioration, type of foundation, coefficient of slope stability, lithologic rock units, slope steepness, groundwater conditions. Natural and man-caused processes affect the emergence of failures. The most common and dangerous are landslides, underfloodings, subsidences, erosion, abrasion and karst. Their intensification occurs as a result of changes in temperature or subsurface water flows.

4. The method for selection of the system of instrumental examinations of underflooding during operation of buildings and structures has been developed.

5. The method for selection of the system of instrumental examinations of vibrations during operation of buildings and structures has been developed. A degree of influence of vibrations on building vulnerability as a function of the peak value of vibration velocity has been estimated by the method of expert estimation. The probability of damages depends on not only the building vulnerability but also the characteristics of threat source.

6. The method for selection of the system of instrumental examinations of landslides during operation of buildings and structures with due account of the vulnerability criterion has been developed. The input data for selection of a system and design of a process (composition, sequence of operations, scope, terms, labor intensity, costs) of measurement work during operation are as follows: stability and steepness of slopes where the building is located, conditions and geological composition of soil base, potential sources of underfloodings and vibrations, whose presence is a threat to stability of slopes. 


\section{SUMMARY}

Research into interactions between construction activities, surrounding territories and neighboring developed areas is an urgent problem when natural and man-caused processes are studied and coped with during construction and operation of buildings. Defects and damages of buildings that have not been detected in good time result in deformations. Their effects result in material, social and ecological losses. Therefore the prompt evaluation of building conditions, the forecasting of trends in development of defects and damages and the elaboration of measures on their stabilization or removal are very important. For that a mechanism of destruction and wearing of structural elements during construction and operation activities shall be understood and the opportunity of estimation of effects of environmental factors shall exist. For this purpose the objective data measured and collected with the use of instrumentation are vital. The work concerns with the principal natural and man-caused factors that affect the serviceability of buildings, in particular, deformations, landslides, underflooding and vibrations that have destructive effects on the operating availability of buildings and structures. The recommendations on determination of an optimal scope of instrumental measurements have been elaborated for such objects that are under construction or operation. Potential losses due to untimely detection of damages are recommended to prevent by sequential estimations of risks of individual, similar to natural and mancaused conditions and geological threats for development areas. The method of determination of the optimal scope of instrumental examinations during operation of buildings and structures with due account of the criterion of vulnerability has been developed. The methods for selection of estimation procedures have been developed: the system of instrumental examinations of underflooding during operation of buildings and structures; the system of instrumental examinations of vibrations during operation of buildings and structures; the system of instrumental examinations of landslides during operation of buildings and structures with due account of the vulnerability criterion. The main parameters of buildings that affect the degree of vulnerability are as follows: type of underground structure, degree of building deterioration, type of foundation, coefficient of slope stability, lithologic rock units, slope steepness, groundwater conditions. The most common and dangerous natural and man-caused processes are landslides, underfloodings, subsidences, erosion, abrasion and karst. Their intensification occurs as a result of changes in temperature or subsurface water flows. 


\section{REFERENCES}

1. National report on the state of man-caused and natural safety in Ukraine in 2014. The State Emergency Service of Ukraine. Kyiv, 2015. [Electronic resource] : access mode http://undicz.dsns.gov.ua/ua/Nacionalnadopovid-pro-stan-tehnogennoyi-ta- (in Ukrainian)

2. Recommendations on estimation of geological risks in the territory of the city of Moscow. - [Electronic resource] : access mode http://aquagroup.ru/normdocs/7677 (15.07.16). - Title on screen (in Russian)

3. SP 11-105-97 System of normative documents in the construction industry. Code of regulations on engineering surveys for the construction industry. Part II. Regulations on production of work in the regions of development of dangerous geological or engineering and geological processes. - [Electronic resource] : access mode : http://docs.cntd.ru/document/1200007405 (15.09.15). - Title on screen. (in Russian)

4. GOST R 52892-2007. Vibration and shock. Vibration of buildings. Measurement of vibration and evaluation of its effects on structure. - M. : Standartinform, 2008. $-20 \mathrm{p}$.

5. Osypov O.F. Construction under conditions of urban development. Experience and prospects / O.F. Osypov, I.T. Hladun // Urban and territorial planning : coll. sci.-techn. art. - K. : KNUBA, 2004. - No. 12. - P. 9.18. (in Ukrainian)

6. VSN 358-76 Instructions on pile driving near buildings and structures. - M. : TsBNTI, 1976. - 54 p. (in Russian)

7. Dudkin E.S. Dynamic effects of municipal transport movement on buildings and structures / E.S. Dudkin // Polzunov Bulletin. 2007. No. 1-2. - P. 30-32. (in Russian)

8. Methodic recommendations for estimation of risk and damage at underflooding of territories. - M., 2001. - 56 p. (in Russian)

9. Mikhailenko V.M., Hryhorovskyi P.Ye., Models and methods of information system for diagnostics of operating conditions of construction projects / V.M. Mikhailenko, I.V. Rusan, P.Ye. Hryhorovskyi, O.O. Terentiev, A.T. Sviderskiy, Ye.V. Horbatiuk. - K. : TsP «Komprynt». - 2018. - 225 p. (in Ukrainian)

10. Recommendations on estimation of geological risks in the territory of the city of Moscow. - [Electronic resource] : access mode http://aquagroup.ru/normdocs/7677 (15.07.16). - Title on screen. (in Russian)

11. Tishin V.G. Fuzzy logic presentation of estimation of vulnerability of buildings and structures during designing and long operation under conditions of uncertainty / V.G. Tishin // Proceedings of Samara Center of 
the Russian Academy of Sciences. - 2011. - V. 13. - No. 4. - P.1034-1040. (in Russian)

12. GOST R 22.8.09-2014. Safety in emergencies. Requirements to safety, risk, and damage levels estimation at underflooding of urban and industrial areas. - M. : Standartinform, 2015. - 42 p. (in Russian)

13. Ruban N.N. Estimation of parameters of dynamic impacts from transport sources under conditions of the city of Dnepropetrovsk / Prospects of development of construction technologies : conf. publ. - 2007. - P. 8695. (in Russian)

14. Litvak B.G. Expert estimation and decision making / B.G. Litvak. M. : Patent, 1996. - 271 p. (in Russian)

15. Hryhorovskiy P.Ye. Selection of optimal methods for monitoring of operating conditions of building structures with the use of utility functions / P.Ye. Hryhorovskiy, N.P. Chukanova // New technologies in construction : coll. of sci. and tech. articles - K. : Publ. «Lira-K», 2014. - Issue 27-28. P. 21-24. (in Ukrainian)

16. DBN V.1.1-25-2009. Protection against dangerous geological processes. Engineering protection of territories and structures against underflooding and flooding. - [Current version 2011-01-01]. - K. : Minregionbud of Ukraine, 2010. - 52 p. - (State building code of Ukraine). (in Ukrainian)

\section{Information about the author: \\ Hryhorovskyi P. Ye.,}

Doctor of Technical Sciences,

First Deputy Director for Science, State Enterprise 'Research Institute of Building Production named of V. S. Balitsky' (SE 'RIBP') 51, Lobanovskyi av., Kyiv, 03110, Ukraine 


\section{ADHERENCE TO CONSUMER RIGHTS AND INCREASE IN SOCIAL RESPONSIBILITY OF BUSINESSES IN ACCORDANCE WITH THE EU STANDARDS ON PROTECTION OF CONSUMER RIGHTS: LESSONS FOR UKRAINE}

\section{Khyzhniak V. O.}

\section{INTRODUCTION}

The sphere of protection of consumer rights is an integral part of the general human rights. Only consumers are not professional participants among all other market entities and they are not able to protect their legal rights efficiently without the state support. Just the satisfaction of consumer demands determines the level of development and civilization of market therefore in the context of development of the national economy this sphere is a realm of urgent and timely studies.

Reforming any sector of the national economy or the state's social block shall be, first of all, accompanied by changes in the corresponding legislative and regulatory-legal framework. Only in such a case can we count on a positive result. Thereby a number of important laws have been passed, in particular, the Law of Ukraine 'On state market supervision and control of non-food goods', the Law of Ukraine 'On responsibility for damages inflicted by defects in products', the Law of Ukraine 'On basic principles and requirements for safety and quality of food products'. At present the intensive work on harmonization of the Ukrainian standards with the European and world ones is carried out as well as the elaboration of necessary technical procedures. Therefore, if we count to attain a proper level of supplies of safe and quality goods to our citizens as a result of reforms in the system of protection of consumer rights there is also a need in 'rebuilding' of the system of technical regulation. As such a system is a base of the whole system of protection of consumer rights.

One of the indicators that characterize the development of any democratic society is a correspondence between civil rights and democratic liberties of every citizen.

One of the fundamental postulates of the sphere of protection of consumer rights recognized by international norms and practices is the freedom of a citizen to choose products and the consumer right to obtain quality products and information about them. 
Those fact that a consumer being a major participant of the consumer market and a principal investor in generation of business capitals and at the same time the most restricted in his/her rights person is paradoxical.

The issue of citizens' rights including the rights in the consumption sphere is urgent as the signing of the Agreement of Association with the EU by Ukraine will demand the application of the European standards on quality of products and the establishment of a basis for implementation the right of every citizen for an adequate level of consumed products and obtained services.

\section{Adherence to consumer rights and increase in social responsibility of businesses}

Analysis of recent studies and publications. The issues of protection of consumer rights and an improvement of businesses' social responsibility have been considered in the scientific publications of domestic scientists: Mandybura V. O., Zakhozhai V.B., Hryshova I.Yu., Krasnoruts'kyi O.O., Mytiai O.V., Shabatura T.S., Koniukhova Yu.M., Hnat'ieva T.M., Herasymova S.V, Paniuk T.P., Yazvins'ka O., Lazareva A., Nikolaieva L., Ivanenko L. and others. Nevertheless, a wide range of urgent issues in the context of the described problems demands further scientific studies.

Thus, according to Mandibura V.O. the issue of the matter of the social and economic category 'consumerism' remains urgent because it is nothing less than a systemic institution of manifestation of consumers' distrust in quality of goods and services available in the market and extension of the comprehension of the matter of mechanisms of systemic provisions for protection of consumer rights on the market of goods and services ${ }^{1}$. According to Hryshova I.Yu. activation of mechanisms of social responsibility of businesses in the context of increasing the competitiveness of economic entities and protecting the consumers' rights is one of the effective means of the consumer policy at the state level that indicates the process of transformations of the economic issues of social nature into value added that is generated by businesses for the account of transformations of its components, use of new competences and possibility of increasing market values ${ }^{2}$.

The purpose of research is a study of methodological approaches to social responsibility of businesses as it relates to consumers and protection of their rights under conditions of transformations of the national economy as well as a study of the organization of a system of customer rights

\footnotetext{
1 Закон України «Про відповідальність за шкоду, завдану внаслідок дефекту в

${ }^{2}$ Гришова І.Ю. Імплементація принципів соціально-орієнтованого бізнесу в площину економічного розвитку потенціалу харчових підприємств
} продукції» 
protection in the EU and possibility of using the useful experience of the European countries for improvement of the Ukrainian legislature in the sphere of protection of consumer rights and mechanisms of its implementation.

Presentation of the major results of the study. There are some basic methodological approaches to the conception of social responsibility that have been considered in scientific publications. In our opinion this conception not only relates to the principles of functioning of businesses in the market competitive environment but also remains one of the priority directions of the state policy in the field of protection of consumer rights ${ }^{3}$. In particular, this is a methodological approach according to which an economic entity is a tool for increasing the market value of business and obtaining additional profits and therefore any its social activity is directed on attaining economic outcomes. Performing such activities a business unit fulfills its economic function, producing goods and services which are necessary for the society and generating jobs and providing maximum profits for owners.

The socio-political approach is based on an assumption that businesses are able to exert some influence on the society and therefore they shall use this ability responsibly. This means the ability to affect the outcomes of important social processes with the aim to find solutions of social problems irrespective of political institutions. The most known conception is a conception of 'corporate citizenship' which formation began early in the early XXI century. According to this conception the role of a business in its narrow sense comes to philanthropy, social investments and some voluntary liabilities to the local society. In a wide sense the economic entity shall be responsible for those fields of its activities in which the state protects the rights of citizens as consumers at the market of goods and services.

The social approach implies the concentration of business activities on defining the social needs of the society and satisfaction of them contributing in that way to the strengthening of economic business positions. In view of this the activities of any businesses in the field of social responsibilities shall be defined by tasks the society entrusts them.

The moral and ethic approach is based on a conception of liabilities of business owners and some managers or enterprises to the society. Attitude of business in Ukraine toward the conception of social responsibility is defined, on the one hand, by the company's origin, its size, industry, location, activity, contacts with final consumers, a level of competitiveness un the market, the company's marketing strategies. On the other hand, the

\footnotetext{
3 Закон України «Про основні принципи та вимоги до безпечності та якості харчових продуктів»
} 
economic conditions in the country, the level of industry development and the correspondence to the current legislation are important.

Certainly, at present the national economy of Ukraine demands structural changes related to the harmonization of social and economic relations. Supplies of investments and reduction of tax burdens are required for widening of possibilities for small and average businesses which drive the economic development in many civilized countries. Then it will be valid to demand social responsibility from businesses and new approaches to the system of protection of consumer rights. Unfortunately the domestic consumer is forced to defend himself/herself permanently and creation of possibilities of full implementation of their rights for safety and quality of products as well as complete information about them is the major task of the state.

If we consider the European system of protection of consumer rights then at first sight it will seem liberal. This is due to a rather high culture level on the consumer market in Europe. For example, in Germany the level of civilized relations on the consumer market is about $95 \%$, in Poland - more than $70 \%$. For the Ukrainian market the estimated are not so favorable, only $20-25 \%{ }^{4}$.

The above gradation corresponds to the quality scale established in the world. By convention it may be divided in 15 stages and Ukraine, unfortunately, Ukraine is not even in the middle of this list. Therefore the system of protection of consumer rights in our country implies a similar state of quality of products and services. When the economic indices grow then the level of consumer market will rises.

At present an active work on harmonization of the Ukrainian legislative economic system with the European one is carried out. Such a work is a need as Ukraine clearly selects a way to the European integration and is a member of the World Trade Organization (WTO). However implementing reforms of the domestic economy we shall not forget those for whom we do all this, the Ukrainian consumers. Thus, the processes of development of businesses and improvement of the system of protection of consumer rights shall proceed in parallel and be interrelated.

In its turn, it is very important to adhere to the interests of manufacturers, traders and consumers in the process of elaboration of a modern model of the Ukrainian economy on the basis of innovation and investment development. Unfortunately, today these interests are wide asunder as pole and pole. The practice shows that the processes of economy deregulation are not directed on attainment of balance between interests of major participants

\footnotetext{
${ }^{4}$ Калита П. Звенья одной цепи: Защита потребителей и товаропроизводителей немислима без интегрирующей основы - качества
} 
on the consumer market. And what is more, they aggravate the imperfect system of protection of consumer rights. The reforms in the business sphere are taking place aggressively and infringe upon consumers' rights stipulated in the Constitution, the Law of Ukraine 'On protection of consumer rights' and other regulatory documents.

Sometimes the reforms in the economy of Ukraine are carried out without due allowance for consumer interests. This is caused by the orientation of the current conception of reforming the national economy on a rather rapid implementation into a civilized market. The major part of domestic businessmen makes every effort to be included into the world ratings. At that they absolutely forget or ignore the consumer rights. Though the consumer is above all an investor of the economy, a party who pays an equivalent for rendered services and supplied goods. Therefore the quality of goods that are included into the basket of goods shall be in accordance with labor that has been put into bought goods. Unfortunately the business not always takes this into consideration and tries to thrust low-grade services or services that do not correspond with their actual prices.

It is entirely obvious that the level of social responsibility of businesses depends on the level of development of both the economy and the society itself. And as the current quality indices of domestic businesses do not correspond to the average level of conducting business in Europe, where we strive for, our businessmen have a notion of social responsibility at a similar level.

First of all, business entities shall understand that the most reliable and profitable partner in development of business is a domestic investor, consumer of their products. Therefore he/she shall be treated with respect. Unfortunately, the practice shows that customers rather often buy products of unknown origin or with expired pull-dates, are cheated in weighing or counting or deceived with false consumer values of products.

We can't hope for rising the social responsibility of business until a favorable economic climate is established in Ukraine and manufacturers understand that customers are their reliable partners.

For some time past the legislation has developed not on the way to protection of consumer rights but other way. Due to efforts of lobbyists who stand up for interests of manufacturers the liberal attitude for those infringements which a manufacturer allows at the consumer market. For example, the changes inserted in the Law of Ukraine 'On protection of consumer rights' restrict the consumer rights in a case of buying low-grade goods. For example, if the consumer has bought a refrigerator and it turns out defective the consumer is given a right to remove defects within the warranty term. In essence, the consumer is obliged to perform repair without an opportunity of returning the defective goods to the trader. Only in a case 
when a complex procedure of expert evaluation is performed and the presence of any material defect of factory origin is confirmed the customer will acquire a right to exchange this goods or terminate a contract. Accordingly he/she will be given back the money but only after huge efforts!

Let's consider the Law of Ukraine 'On principles of the state supervision (control) in the field of economic activities' that at first sight reduces the pressure on business from the side of regulatory authorities. But, on the other hand, the legislation restrains the consumer rights even more. There is no such a conception as 'a 10-day notification about the check-up' in any country in the world. What is the sense in such a check-up? At best, the regulatory authorities will find the facility intended for check-up with removed defects. At worst, the auditors would find a lock on doors or absent management who emergently went on sick leave if they had had no time to hide the defect goods. Thus, the auditor arrives and establishes only the fact of the check-up. Also the periodicity of checks-up is not specified and should be established in accordance with a scale of risks while the notion of risk remains unspecified. In practice such a policy moves a businessman out of the field of supervision and regulation and leaves a consumer without any guaranteed protection of the law.

At present the most part of bills approved by the Parliament is directed on strengthening of businesses and stands up for the interests of enterprises and specific sectors of the economy. At that nobody says about the necessity to strengthen the social responsibility of businesses. The European experience indicates that the application of high economic penalties and sanctions may be an effective weapon in a struggle for the civilized market. First of all these sanctions shall be directed against selling of falsified or counterfeit products and products that are unsafe for human health and life. It's a different matter that the problem can't be solved by increasing only penalties.

It's obvious that for such violations as cheatings of consumers in counting and measuring it is necessary to decrease an amount of financial losses for which a prosecution is possible. Now such violations thrive in particular in markets and small shops. There are cases of product shortages, underfilling of spirits in catering outlets. To appeal to a businessman's or retailer's conscience is a bad job. The approaches shall be changed.

It is necessary to seek a balance: not only violators shall be punished financially but responsible businessmen shall be encouraged by economic preferences, decreased tax burden etc. Because of this businessmen will be interested in selling high-quality goods and rendering high-quality services.

It is necessary to reform the customer rights system. In its turn this depends on businessman's interests in proper conducting business activities. Just here there are roots of a new policy and reforms which may become a 
basis for development of corresponding regulatory and legal acts. It is necessary to arrange conditions under which the cooperation with consumers and respectful consideration of their interests will be profitable for manufacturers. In their turn customers shall have a well-defined and transparent protection system which shall guarantee the observance of all their constitutional rights.

\section{The eu standards on protection of consumer rights: lessons for Ukraine}

Protection of consumer rights is an urgent issue in the context of assurance of sectoral cooperation between the EU and Ukraine that is specified in the Agreement of Association between the EU and Ukraine (hereinafter as 'the Association'). The goal of the cooperation is harmonization of the current legislation of Ukraine with the legislation of the European Union to ensure the customer rights to high-quality and safe for health and life products and removal some 'gaps' between the European and Ukrainian systems of consumer rights protection. In particular, this cooperation comprises expert evaluations of legislative and institutional reforms, establishment of a standing system for exchanging data on unsafe products, refinement of information given to consumers especially about prices, characteristics of supplied goods or rendered services, training of official managerial persons and other representatives of consumers, development of exchanges between representatives of consumers and deepening of the policy in the field of consumer rights protection.

According to the Agreement of Association Ukraine is performing the step-by-step harmonization of the Ukrainian legislation with the EU legislation in the field of consumer rights protection specified in Appendix XXXIC to the Agreement of Association. At that time Ukraine tries to avoid creation of trade barriers.

According to Appendix XXXIX to Chapter 20 of the Agreement our country has 3 years for harmonization of the major part of documents and 5 years for harmonization with the Procedure No. 2006/2004 on cooperation in the field of consumer rights protection.

The protection of consumer rights in the field of sales is ensured by the corresponding provisions of the Laws of Ukraine 'On consumer rights protection', 'On the state market supervision and control of non-food products', 'On general safety of non-food products'. Unfortunately, the major part of the EU's secondary legal acts in the field of consumer rights protection are not implemented in full measure as there are some collisions in the current legislation of Ukraine that shall be corrected before the end of the implementation period of the Agreement of Association. 
First of all, it concerns contract laws, product safety, distance contracts signed beyond commercial facilities etc.

An economic mechanism of any society in which manufactured products are goods whose interchanges are carried out in accordance with the law of value will require the corresponding legal forms of arrangement of goods turnover and transition of goods from manufacturers to consumers.

As it is known, the contract is one of the most widespread reasons of the origin of civil liabilities. Just the contract of sales is a device that mediate relations concerning payable alienation of property from some persons in favor of others including those who are defined as consumer-buyers by the law.

One of the main constitutional rights of any citizen whose implementation demands the establishment of certain guarantees is a consumer right to acquire goods of proper quality. Thus, according to Article 50 of the Constitution of Ukraine: 'Every person shall have a right to the environment that is safe for health and life and compensation of damages inflicted as a result of infringement of this right. A right to free access to information about the environmental conditions, quality of food products and amenities as well as a right to disseminate such information are guaranteed. Such information shall not be classified as secret ${ }^{5}$.

The market of Ukraine is permanently saturated with various goods of domestic or foreign origin though they are not always of proper quality.

Some provisions of the Law of Ukraine 'On consumer rights protection', in particular Article 8 that defines the rights of consumer in a case of acquiring of goods of improper quality, restrict the consumer rights and do not account for all requirements specified in certain provisions of the European legislation, therefore such provisions shall be brought into accord with the EU laws with respect to renewal the customer right to change products of low-grade and compensation for damages.

According to Article 8 the customer rights are differentiated into the rights for goods bought with 'defects' and the rights for goods bought with 'material defects'. In a case of acquisition of goods with defects the customer has a right to demand a proportional decrease in the price from the trader or manufacturer, free elimination of defects in goods within a reasonable period of time or compensation of expenditures for elimination of defects in goods.

Only in a case of detection of material defects the consumer has a right to demand termination of the contract and repayment. At that just the consumer shall provide the major part of the basic evidence of presence of material defects, that is the consumer shall apply such a legal framework in which the

\footnotetext{
${ }^{5}$ Конституція України
} 
presence of a material defect shall be only established by means of logical interpretation of the consumer rights. This significantly complicates the realization of his/her rights to termination of the contract and repayment.

It is necessary to consider the notion 'material defect' profoundly. According to the Law the 'material defect' is a defect that makes the use of goods impossible or inadmissible for its target purpose; it has originated from a fault of the manufacturer (trader, contractor); after removal the defect occurs again as a result of causes that are independent of consumer's actions. At that such a defect posses at least on of the following features: it can't be removed at all; or for its removal more than fourteen days will be required; or it makes the goods significantly different from what the contract provides for.

Thus the consumer can terminate the contract of sales and get his/her money paid for the recently bought low-grade goods back only in a case when the defect is material and certified on a proper way by a service center that renders services and performs repairs of consumer goods. Therefore the consumer can demand repayment from this trader of goods subject to the ascertainment of the failure (the material defect) from the fault of the manufacturer or trader and after attempts to remove the defect of goods.

At the same time Article 3, Directive 1999/44/ EC, which concerns some aspects of sales of consumer goods and related warranties and stipulates the consumer rights when the goods of improper quality have been purchased, gives a consumer the right to free removal of defects by means of replacement or repair of the goods, or decreasing their price, or termination of the contract related to the goods. At that the above-mentioned Directive does not stipulate any differentiation of defects into 'defects' and 'material defects', and termination of contracts is possible in a case of any incompatibility of goods.

At the same time, according to item 6, Article 3, Directive 1999/44/ EC a consumer does not have a right to terminate the contract if incompatibility is insignificant.

This European practice may be useful for the Ukrainian legislator. A legal provision that gives a consumer the right to change the goods of improper quality or terminate the contract of sales when he/she has purchased the goods with defects or the goods do not comply with the requirements for them or the terms of contract shall be applied in the legislation of Ukraine concerning the consumer rights protection.

Only some groups of goods of improper quality may be excluded: defects in buildings or structures, cars, pieces of furniture, which has been sold or manufactured with defects that may be removed without significant material expenditures. For example, when a car has been sold with a defected inoperative headlight or other auxiliary it is impractical from economic point 
of view to give a customer the right to unconditional termination of the contract of sales.

Assurance of a competent selection of goods, work, or services is the main purpose of provision of information about them. Such information shall include the designation of goods, their quality, conditions of use, warranties and others. The manufacturer (contractor, trader) shall define the required scope of such information on his/her own. At that he/she shall remember his/her responsibility for incompleteness of provided information according to the law.

According to the Law of Ukraine 'On consumer rights protection' a consumer has a right to get necessary, accessible, reliable and timely information about products as the assurance of the possibility of deliberate and competent choice of them. In particular, Article 15 of the Law regulates the consumer right to get necessary, accessible, reliable and timely information which shall include the following:

1) name of goods, designation or reproduction of a mark for goods and services under which they are sold;

3) data on basic properties of products, rated quantity (mass, volume, etc), conditions of usage;

4) information about the content of harmful for health substances which are designated by the regulatory and legal acts and the warnings relating to the application of some products if such warnings are set by the regulatory and legal acts;

5) note of presence of genetically modified organisms in the product composition;

6) data on price (tariff), terms and rules of acquisition of products;

6-1) if doubtful information about products has been revealed (under the stipulation that the products are not harmful for life, health or property of the consumer) the manufacturer (trader) shall withdraw the products from the market and bring the information into accord;

7) date of production;

8) information about terms of storage;

9) manufacturer's (contractor's) warranty;

10)rules and terms of safe and effective use of products;

11)expiration date (service life) for the goods (consequences of work), information about necessary actions of the consumer after the expiration date and possible consequences if they will not be fulfilled;

12)name and location of the manufacturer (contractor, trader) and a company which performs his/her functions related to claims of the consumer as well as repair and maintenance operations.

Directive EC No. 1169/2011 of 25.10.2011 'On provision of food information for consumers' has an object of attaining a high level of 
protection of consumers' health and guaranteeing their rights to get information. This object is assured by proper distribution of information about consumed food products among the consumers. Customers' choices of food products may be affected (but not limited to) by the marking related to health, economic issues, protection of environment, social or ethical issues.

The analysis of Directive EC No. 1169/2011 of 25.10.2011 'On provision of food information for consumers' shows that in addition to the basic information about a food product for provision of which consumers have the right it also regulates the requirements for food producers to indicate the information about a country and place of food origin.

This means that in accordance with the Agreement of Association Ukraine shall bring the Law of Ukraine 'On consumer rights protection' into accord with the above-mentioned Directive in regards to insertion of changes related to the indication of information about country and place of origin of food products on their labels.

The necessary information about products means it completeness. The current legislation of Ukraine is based on the assumptions that consumers do not have sufficient knowledge of goods, work or service they want to consume. But the trader (manufacturer, contractor) is a professional who knows all about the goods to be sold, the job to be done or the service to be rendered. Therefore he/she shall provide the information for consumers in such amount that they can obtain a clear idea of product properties, its quality, safety, rules of usage, and on the basis of this information consumers can make a competent choice of products which are required and suitable for them.

In addition, there is no any provision for indication of the production lot which is one of the compulsory component of the compulsory information about food products in the Law of Ukraine 'On consumer rights protection'. In that way, owing to this indication on the food product introduced into the market the production lot related to this product can be identified. According to item 59, Part 1, Article 1 of the Law of Ukraine 'On basic principles and requirements to safety and quality of food products' 'a lot is any amount of food products under the same name and with the same properties, this amount is determined by the market operator and produced for the period of time which is determined by this operator, under the same production conditions and at the same facility'. Part 6, Article 37 of this Law stipulates that 'when any unsafe food product is a part of a lot or shipment of food products of the same designation it shall be considered that all food product under this designation in this lot or shipment are also unsafe and their further turnover shall be prohibited until the next detailed evaluation will demonstrate that the rest of the lot or shipment is safe'. So, the number of production lot is one of the integral component of the compulsory 
information about the food products and the compulsory requirement to the marking of food products (paragraph 10, item 6 of the approved order of the State Committee of Ukraine on issues of technical regulations and consumer policy of 28.10.2010, registration number 487 'On approval of the Technical Procedures related to the marking rules for food products'). Thereby, we consider that the Law of Ukraine 'On consumer rights protection' shall be supplemented with the provisions for identification a production lot as the compulsory information that shall be provided for. Therefore it is advisably to provide the procedural requirements for identification of a production lot of food products.

In the field of consumer rights protection an urgent issue is an unfair practice of product sales applied by economic entities in relations with consumers. In the EU such a practice is named 'unfair commercial practices'.

Thus, according to Article 1 Directive No. 2005/29/EC of 11.05.2005 on unfair commercial practices is intended to assure proper functioning of the internal market and attain a high level of consumer interests protection by bringing the laws, resolutions, administrative provisions of the memberstates concerning unfair commercial practices that are harmful for economic interests of customers into accord. The directive is applied to business-toconsumer practices that are used before, during or after signing a contract related to the product (Part 1, Article 3).

The Directive is a legislative enactment of maximum harmonization therefore the member-states don't have any right to keep or adopt any additional rules in this field at the national level.

Articles 5 to 9 of the Directive describe unfair commercial practices. The Directive prohibits both actions and inactivity that deceive as well as aggressive commercial practices including the use of molestation, compulsion and abuse of power. Annex 1 to the Directive comprises specific examples of commercial practices which in any case are considered as unfair. The list comprises 23 examples of unfair and 8 examples of aggressive practices.

The member-states shall ensure the existence of independent and effective measures to counteract unfair commercial practices and comply with the provisions of the Directive in the interests of consumers (Part 1, Article 11). Such measures include the right of private persons or institutions having legal interests in combating unfair commercial practices (including their competitors) to take legal measures against such practices (go to the law or appeal to other state authorities). The member-states shall establish effective, proportional and retaining sanctions for infringement of the national legislation that implements the provisions of the Directive (Article 13). 
The issues of unfair (dishonest) commercial practices in Ukraine are regulated by the Laws of Ukraine 'On consumer rights protection' and 'On protection against unfair competition'.

According to Part 1, Article 19 of the Law of Ukraine 'On consumer rights protection' any business practice that is dishonest shall be prohibited. Such a practice includes: commission of actions or inactivity, which deceive the consumer or are aggressive, or manifestation of unfair competition. For every type of unfair practice the Law gives a corresponding example whose list is not exhaustive. Also the important provision is item 1, Part 1, Article 21 of the Law of Ukraine 'On consumer rights protection'. According to this provision the consumer rights shall be considered as violated when during the realization of product the right of consumer to free choice of products is violated in some way. Article 22 of the Law regulates the issues of remedial measures.

The provisions for prohibition of unfair (dishonest) commercial practices in the current legislation of Ukraine are very similar with the Laws of the EU. The given examples of unfair practices stipulated in Article 19 of the Law 'On consumer rights protection' cover a great number of examples listed in Annex 1 to the Directive. Nevertheless not all compulsory provisions of Directive No. 2005/29/EC are taken into account in the Ukrainian legislation. For example, the notion of unfair commercial practice by the Directive does not correspond with the notion of dishonest business practice by the Law of Ukraine 'On consumer rights protection'. Taking into account the Directive's nature as the enactment of maximum harmonization it is necessary to bring the list of examples of deceitful and aggressive practices stipulated in the Ukrainian legislation into accord with the list presented in Annex 1 to the Directive. Furthermore, there some discrepancies in the characteristic of the notions 'misleading commercial practice' (Article b I 7 of the Directive) and 'dishonest business practice that deceives' (Part 2, Article 19 of the Law). The Law of Ukraine 'On consumer rights protection' does not account the corresponding provisions of the Directive.

\section{CONCLUSIONS}

In our opinion the most comprehensive and substantiated methodological approach is the disclosing of economic content of the attribution 'Social responsibility of business' according to which a contribution of the economic entity into the society, which has been created with the use of the company's social investments, its basic activities and charity, allows the execution of its functional tasks of a business unit subject to requirements and rights of consumers in the market of goods and services. 
Protection of consumer rights in the field of commerce is assured by the corresponding provisions of the Laws of Ukraine 'On consumer rights protection', 'On state market supervision and control of non-food products', and 'On general safety of non-food products'. The major part of the EU's secondary legal acts in the field of consumer rights protection have been underimplemented, there are some collisions in the current legislation of Ukraine, which shall eliminated in accordance with the Agreement of Association between the EU and Ukraine.

According to the current legislation of Ukraine the customer can terminate the contract of sales and recover money for low-grade goods bought recently only in a case if the detected defect is material and certified in a certain way by a corresponding service center that performs maintenance and repair of consumer goods. Therefore, the customer can demand repayment from such a trader of goods under the condition that it has been established that defects (material defects) had occurred through the manufacturer's or trader's fault and only after attempts to repair the goods. At the same time Article 3 of Directive No. 1999/44/EC concerning some aspects of sales of consumer goods and related warranties gives customers the right to free removal of defects by replacement or repair the goods, or price reduction, or termination of the contract related to these goods. According to the Agreement of Association Ukraine shall bring the Law of Ukraine 'On consumer rights protection' as regards the insertion of changes related to the indication of information about the country and place of goods origin on food-products with the above-mentioned Directive.

Also, the Law of Ukraine 'On consumer rights protection' doesn't contain a provisions for identification of a production lot while such information is a compulsory part of the compulsory information about food products according to the EU's standards.

The provisions for prohibition of unfair (dishonest) commercial practices in the current legislation of Ukraine are very similar to the EU's laws. The examples of unfair practices that are provided and shown in Article 19 of the Law 'On consumer rights protection' cover many examples contained in Annex 1 to the Directive. Nevertheless not all compulsory provisions of Directive No. 2005/29/EC have been taken into account in the current legislation of Ukraine.

\section{SUMMARY}

Reformation of the economy, harmonization of the Ukrainian legislation with the European standards, and arrangement of favorable conditions for development of businesses shall be coordinated with improvements in the system of protection of consumer rights and raising social responsibility of business. That is why the analysis of experience in assurance of legitimate 
consumer rights related to products safety and quality is an important part of the scientific support for development of these processes under domestic conditions in the context of the general process of market reforms and strengthening the social responsibility of businesses.

The work deals with the EU standards on consumption which are designed for establishment of a high level of consumer rights protection for free movement of goods in the EU's internal markets. The main issues of consumer rights protection in Ukraine have been considered in the context of harmonization of the current legislation of Ukraine with the legislation of the European Union for the purpose of improvement of end-products safety and quality.

\section{REFERENCES}

1. Закон України «Про відповідальність за шкоду, завдану внаслідок дефекту в продукції» від 19.05.2011 р. № 3390-VI [Електронний pecypc]. - Режим доступу : zakon.rada.gov.ua/laws/show/3390-17

2. Гришова І.Ю. Імплементація принципів соціально-орієнтованого бізнесу в площину економічного розвитку потенціалу харчових підприємств/ І.Ю. Гришова, Т.С.Шабатура// Економіка: реалії часу. Науковий журнал. - 2014. - № 3.- С. 13-22. - Режим доступу до журн.: http://economics.opu.ua/files/archive/2014/n3.html

3. Закон України «Про основні принципи та вимоги до безпечності та якості харчових продуктів» від 22.07.2014 p. № 1602-VII [Електронний ресурс]. - Режим доступу : http://radakmu.org.ua/uploads/ file/-/280915_01.pdf.

4. Калита П. Звенья одной цепи: Защита потребителей и товаропроизводителей немислима без интегрирующей основы качества /П.Калита- Споживач. - 1997 - № 8.

5. Конституція України [Електронний ресурс]. - Режим доступу : http://zakon3.rada.gov.ua

6. Закон України «Про захист прав споживачів» від 12.05.1991 р. № . № 1023-XII [Електронний ресурс]. - Режим доступу : zakon.rada.gov.ua/laws/show/1023-12.

7. Закон України «Про державний ринковий нагляд і контроль нехарчової продукції» від 02.12.2010 p. № 2735-V [Електронний pecypc]. - Режим доступу : zakon.rada.gov.ua/laws/show/2735-17.

8. Захожай В.Б. Управління якістю: навч. посіб. для студ. вищ. навч. закл. /В.Б. Захожай, Н.Г. Салухіна, О.М. Язвінська, А.Ю. Чорний; за наук. Ред.. В.Б. Захожая. - К.: ДП «Вид. дім «Персонал», 2011. - 936 с.

9. Мандибура В. О. Особливості формування Інституту довіри в системі забезпечення якості споживання та захисту прав споживачів / 
В. О. Мандибура, С. Г. Батажок // Вісн. Ін-ту економіки та прогнозування. - 2009. - № [1]. - С. 69-73.

10. Гришова І.Ю. Соціальна відповідальність бізнесу як чинник соціально-економічного розвитку / І.Ю. Гришова, М.Ю. Щербата, В.В.Гришов// Проблеми і перспективи економіки та управління : науковий журнал / Черніг. нац. технол. ун-т. - Чернігів : Черніг. нац. технол. ун-т, 2015. - № 3 (3). - С. 17-28.

11. Герасимова С.В. Узагальнення підходів до визначення консюмеризму як соціально-економічної категорії // Актуальні проблеми економіки. - 2005. - № 12. - С. 76-79

12. Гнатьєва Т.М. Соціальна відповідальність бізнесу як інструмент ефективності корпоративної стратегії/ Т.М. Гнатьєва // Вісник Чернігівського державного технологічного університету. - Чернігів. 2014. - № 2(74). - С. 35-45.

13. Гнатьєва Т.М. Вплив соціальної відповідальності бізнесу на конкурентоздатність підприємств аграрного сектору / Т.М. Гнатьєва, О.В. Ніколюк // Вісник Чернігівського державного технологічного університету. - Чернігів. - 2014. - №4(76). - С.151-158.

14. Красноруцький О.О. Концептуальні засади здійснення корпоративної соціальної відповідальності харчовими та переробними підприємствами / О. О. Красноруцький // Науковий вісник Херсонського державного університету. Серія «Економічні науки». Вип. 10. - Ч. 3. - 2015. - С. 52-54.

15. Панюк Т. П. Роль соціальної відповідальності бізнесу в діяльності молокопереробних підприємтсв. / Т. П. Панюк // Проблеми і перспективи економіки та управління : науковий журнал / Черніг. нац. технол. ун-т. - Чернігів : Черніг. нац. технол. ун-т, 2015. - № 2 (2). C. $118-122$.

16. Митяй О.В. Социальная ответственность бизнеса как направление улучшения социального развития агропромышленных предприятий / О.В. Митяй // Социальная ответственность бизнеса: международная научно-практическая конференция (Тольятти, 10-11 декабря 2014 года): сборник научных трудов / отв. ред. Ю.А. Анисимова. - Тольятти: Изд-во ТГУ. - 2014.- С. 46-56

17. Закон України «Про державний ринковий нагляд і контроль нехарчової продукції» від 02.12.2010 р. № 2735-V [Електронний pecypc]. - Режим доступу : zakon.rada.gov.ua/laws/show/2735-17.

18. Закон України «Про загальну безпечність нехарчової продукції» від 02.12.2010 р. № 2736 - VI [Електронний ресурс]. - Режим доступу : zakon.rada.gov.ua

19. Язвінська О.М. Історія консьюмеризму в США / О.М. Язвінська // Гуманітарні науки і сучасність. - К., 2002. 
20. Лазарева А. Захист споживачів у Франції /А. Лазарева // Споживач. - 1997. - № 7.

21. Захист прав споживачів: соціально-правовий аспект /За заг. ред. Л.В. Ніколаєвої. - К.: КНТЕУ, 2002. - С.312.

22. Іваненко Л.М. Правове регулювання захисту прав споживачів: Навч. посіб. - К.: КНТЕУ, 2008. - С.258.

23. Лащак В.В., Лащак Т.В. Система захисту прав споживачів у провідних країнаї світу /В. Лащак, Т. Лащак //Наукові записки «Острозької академії», серія «Економіка», випуск 25, 2014 р. - С. 15-18.

\section{Information about authors:} Khyzhniak V. O.,

Candidate of Economic Sciences, Director of the State Enterprise, «Research Institute of Building Production named of V.S. Balitsky» 51, Lobanovskyi av., Kyiv, 03110, Ukraine 


\title{
IMPLEMENTATION OF SCIENTIFIC, ANALYTICAL AND APPLIED TOOLS OF ORGANIZING INVESTMENT IN A MODERN DEVELOPMENT SYSTEM
}

\author{
Ryzhakova G. M.
}

\section{INTRODUCTION}

In recent years, the construction industry in Ukraine demonstrates a consistent tendency towards the growth of a significant number of financially incapable and failing enterprises unable to fulfil their obligations before customers, investors and creditors timely and to the full extent. Such situation has exacerbated under the influence of the global financial and economic crisis and has had an impact on almost all kinds of economic activities of the construction market players. An efficient system to prevent bankruptcy is crucial, especially in the times of economic crisis, when economic entities face the loss of capital, payment crisis, decline in production, shrinkage in capacities, and closure of work places, which gives rise to economic and social problems in their further functioning.

Theoretical aspects of investment and issues of government regulation of investment activities were elaborated on in the works of such authors as H. Alexander, J. Bailey, V. Berence, J. Brigham, S.D. Bushuiev, V.M. Heietz, A.F. Hoiko, Ya.A. Zhalilo, J. Canes, F. Kene, P.M. Kulikov, T. Kun, T.S. Marchuk, M.I. Tuhan-Baranovskyi, V.O. Pokolenko, G.M. Ryzhakova, L.V. Sorokina, S.P. Stetsenko, V.H. Fedorenko, D.O. Chernyshev, Yu.A. Chupryna, J.R. Hicks, S.M. Shkarlet, W. Sharpe. However, a number of unstudied issues remain despite a rather extensive exploration of many theoretical and methodological issues and practical developments concerning the mechanisms of the state regulation of investment activities in various spheres of economy, including in the sphere of state-controlled development. Giving a credit to the scientific, practical and methodological contribution made by the mentioned scholars, it should be mentioned that the analytical framework for forming an economic outline of the investment mechanisms and provision of investment resources for real investments do not meet the current requirements of preparation and implementation of the residential development cycle from initiation to commissioning of residential and property developments. The most urgent need on the agenda is the need to renovate the methodological approach and tools for selecting economically sustainable mechanisms of residential 
development and search for rational variants of investment support for residential development projects.

The problems of investment in construction sphere are of immediate interest, as the reference points determined by the market economy development, tightening the market requirements to technical and economic offers in construction, the necessity for building projects to meet a wide range of investment resources, growing possibilities of architectural and construction practice, social needs of the population. The changeover to a new type of economy in Ukraine necessitated an overview of investment and construction companies' activities. Currently, the activities of these structures are formed within an investment portfolio, which makes it necessary for developers to search for investors, thoroughly assess each project, form mutually profitable alliances with business partners, search effective tools of promoting goods on the market etc. Many domestic and foreign scholars tackle the issue of improving the methods of investment management, which highlights the salience of this issue and its significance for the further development of market relations, as well as of economic and architectural and construction sciences.

Hence the applied scientific aim of this research is the development of a conceptual model of a problem-oriented differentiated choice of sources of resourcing of investment and construction projects in housing construction, a high-quality and user-friendly assessment mechanism, striking a balance and managing the social value of housing along with its monetary value.

\section{Conceptual model of a differentiated attraction of resourcing sources of investment and construction projects}

In the current context, construction industry is one of the most requested by the society and state due to its social orientation and investment requirement. Investment processes in the construction sphere must provide a sufficient recovery of enterprises' means of production, kinds of economic activity within the national economy through creating new objects, expanding existing facilities, ensuring their reconstruction or technical reequipment. Construction is one of the largest consumers of adjacent markets' products (chemicals and chemical raw materials, mechanical, electric and other kinds of equipment) and related services. As the construction sphere has such economic significance and is so deeply integrated in related kinds of economic activities, its level of development has a considerable impact of the state of economy as a whole. Also, investing in construction allows to solve important social and economic problems: providing citizens with housing, modernizing obsolete communal infrastructure, renovating housing stock, constructing and reconstructing amenities. A weak investment activity on the part of the state, enterprises 
and population, high intra-industry competition and monopoly of certain construction companies, administrative red tape, as well as failings of technical regulation, lack of balance between construction norms and regulations with international standards negatively impact business activities in the construction sphere.

Today, management of investment and construction projects in housing construction sphere (ICPHC) in Ukraine faces a vast uncertainty and constantly growing complexity of market environment of the projects, high risks of their implementation, lack of funds for financing and low purchasing power of housing consumers, low quality of construction works, imperfect legislative and regulatory framework in the sphere and other difficulties. On the other hand, consumers face the lack of high-quality and affordable housing on the market. Many housing construction projects have been put on hold or frozen. In Ukraine, state programs aimed at providing housing to citizens are ineffectual or underfinanced. Despite the fact that around $60 \%$ of housing construction (HC) in Ukraine is financed by citizens' own money, even the least risky financing schemes lead to failure of projects in over $12 \%$ of cases ${ }^{1}$. The problem of improving the provision of population of Ukraine with high-quality, affordable housing with minimal risks of housing project implementation is undoubtedly top of the agenda. According to the scientific research hypothesis, to solve this problem, principles of managing ICPHC should be reviewed along with the obvious measures to stabilize economy, attracting investments, improvement construction-related legislation, rising the living standards for population etc., using project management tools, stakeholder theory, and evolutionary axiology. Emphasis should be shifted from the maximization of construction companies' profit through building residential objects to raising the level of satisfaction with the results of socially meaningful housing projects for all their stakeholders. The principle of striking a balance of interests of all stakeholders used both within separate construction project and within the whole branch, will promote further development of the construction sector of economy as a driving force of the economy at large, rather than principles of maximizing the profit of one of the project stakeholder. The system of ICPHC management requires a more detailed research and improvement. Due to a large number of failed projects, it is necessary to review the approaches to $\mathrm{HC}$ management. To circumvent the ideas of profit maximization, the value of housing projects (HP) should be expressed in non-financial indicators. The system of value-oriented HP management should encompass a period

1 Residential housing financing schemes in Ukraine. Special features of attracting investments into construction [Electronic resource] // Materials of KLN Consult web-site // Available at: http://www.kln.com.ua/content/view/87/102/lang,ua 
from the investment idea of the project to de-commissioning of a residential building. Defining the value of investment and construction housing projects in non-financial indicators is very important for socially significant housing projects. Successful construction of housing which provides value for all stakeholders has a great social relevance for the population of the country in need of such housing ${ }^{2}$.

The development of national economy depends much on the level of investment activity of domestic enterprises. Finding the ways to mobilize domestic sources of financing investment projects and attracting investment resources in the production are essential pre-requisites for the activation of investment activities of domestic enterprises, their stable development, rising the competitiveness of the domestic industry, and economic recovery for Ukraine overall. The formation of developer companies as integrated production units on the construction market enables the activization of investment activities of enterprises thanks to the scale and synergy effect, by pooling the financial, material, labor, intellectual and information potential of the enterprises participating in the integrated structure, and engaging it in the investment process.

A retrospective view of the development of the methods of economic assessment of investment financing sources established that the first economic assessment methods for investment programs were approximate solutions providing for a certain search of projects and variants of implementation thereof. The second group of methods was formed by the methods of validation of investment programs and financing thereof by the criterion of the improvement of the investor's situation. The third group consists of the most widely spread modifications of the investment sources selection method based on a certain set of characteristics: price and resource availability, financial risks, loss of control over the enterprise management. However, the methodologies for evaluating the innovative and investment activities of construction enterprises and attraction of financing sources were not used by these methods ${ }^{3}$.

Economic assessment of financing sources is a kind of management activity which allows to detect and measure, by using respective methodological tools, the basic cause-and-effect relations between the innovative and investment activities and attracting sources of financing thereof, to determine, within and outside of the enterprise, the main ways

${ }^{2}$ A.I. Rybak. Value-based management of investment and construction residential projects [Text] / A.I. Rybak, I.B. Azarova // Management of complex systems development. - 2013. № 24. - pp. $49-56$.

3 Residential housing financing schemes in Ukraine. Special features of attracting investments into construction [Electronic resource] // Materials of KLN Consult web-site // Available at: http://www.kln.com.ua/content/view/87/102/lang,ua - pp. 82-87. 
and mechanisms of reaching the milestones or expected results of resourcing innovative and investment activities depending on the depth of the enterprises' need for resources and the functionality of their sources.

The existing tools of economic assessment of financing sources are in fact built upon factoring in of two important aspects: the economic substance of the price and its connection with the expenditures related to the attraction of sources. It is the price of the source which is a priority tool for its economic assessment, which is used in the process of innovative and investment activities to: select the financing methods and sources based on the comparison of prices thereof; form a better structure of financing sources; capital budget planning; use in establishing the economic feasibility of investments as a discount rate. Unfortunately, the existing approaches do not present the price as an economic assessment tool to evaluate other conditions for attracting investment sources and characterizing them from the enterprise's point of view as to the source's availability and effects of its use.

The differential approach, described as an alternative way of economic assessment and source attraction, is free of such deficiencies. It allows to range the financing sources both from the point of view of quantitative analysis and from the point of view of qualitative factors influencing the adoption of decisions dealing with innovations and investment. Its implementation and feasibility are based on the expert evaluation results.

The use of the differential approach to the economic assessment of financing sources and alternative resources allows to: a) define the really necessary total amount of finances for the project implementation, which is substantially lower than the perceived amount; b) find more variants of attracting the sources of resources and asses alternative resources and sources thereof; c) reduce the time for choosing the sources, their assessment, and cut the cost thereof.

It is proposed to use the problem-oriented choice of sources of financing depending on the goals and tasks of the enterprise development (fig. 1)

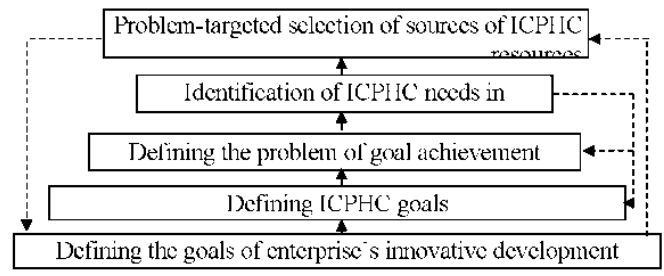

Fig. 1. A simplified conceptual model of differentiated attraction of resourcing sources 
The theoretical framework of the approach is created by: a) the hierarchy of the sources of financial and alternative resources, resourcing; b) classification of sources and factors of impact on the economic assessment and attraction of financing sources; c) classification of main goals; d) indicators' functional capabilities for economic assessment and source attraction ${ }^{4}$.

The sources of resourcing are a set of economic units and their attributes capable of providing a range of resources which satisfy its needs. The sources of financing are a set of economic units capable to providing a range of financial resources which satisfy its financial needs. The sources of alternative resources are a set of business entities and their attributes potentially capable of providing a range of resources in kind which satisfy certain naturalized needs and are capable to substitute financial resources for a certain time or permanently. The choice of the sources of resourcing is made in four spheres, each of which has its own conditions, limitations and indicators: internal and external sources of financial and alternative resources.

Similarly, goals have two basic characteristics of classification: a) directionality or nature. Goals may be of market, production, organization, economic, social and environmental directionality; b) event horizon, by which they are classified into current and project ones. Current goals include the set of current goals of all of the enterprise's innovative and investment projects at different implementation stages. Project goals are the goals of one specific project only.

The scheme of a construction enterprise's goals of innovative and investment activities gets into its final form when it is drawn out with due regard of individual characteristics of an enterprise: its mission, size, state, current or project directionality of goals, special features of the region and area it operates in.

When choosing a development goal, a construction enterprise determines the sphere where it will implement its innovative and investment activities. The goal and the sphere, in their turn, determine the issues to be tackled by the construction enterprise.

This is taken account of by the proposed conceptual model of a problemtargeted differentiated choice of resourcing sources for ICPHC, presented in a simplified (fig. 1) and full (fig. 2) forms.

\footnotetext{
${ }^{4}$ Pokolenko V.O. Introducing the tools for choosing the alternatives of construction project implementation by functional and technical integrity of implementing organizations / Pokolenko V.O., Ryzhakova G. M., Prykhodko D.O. // Management of complex systems development. 2014. - Issue 19. - pp. 104-108.
} 


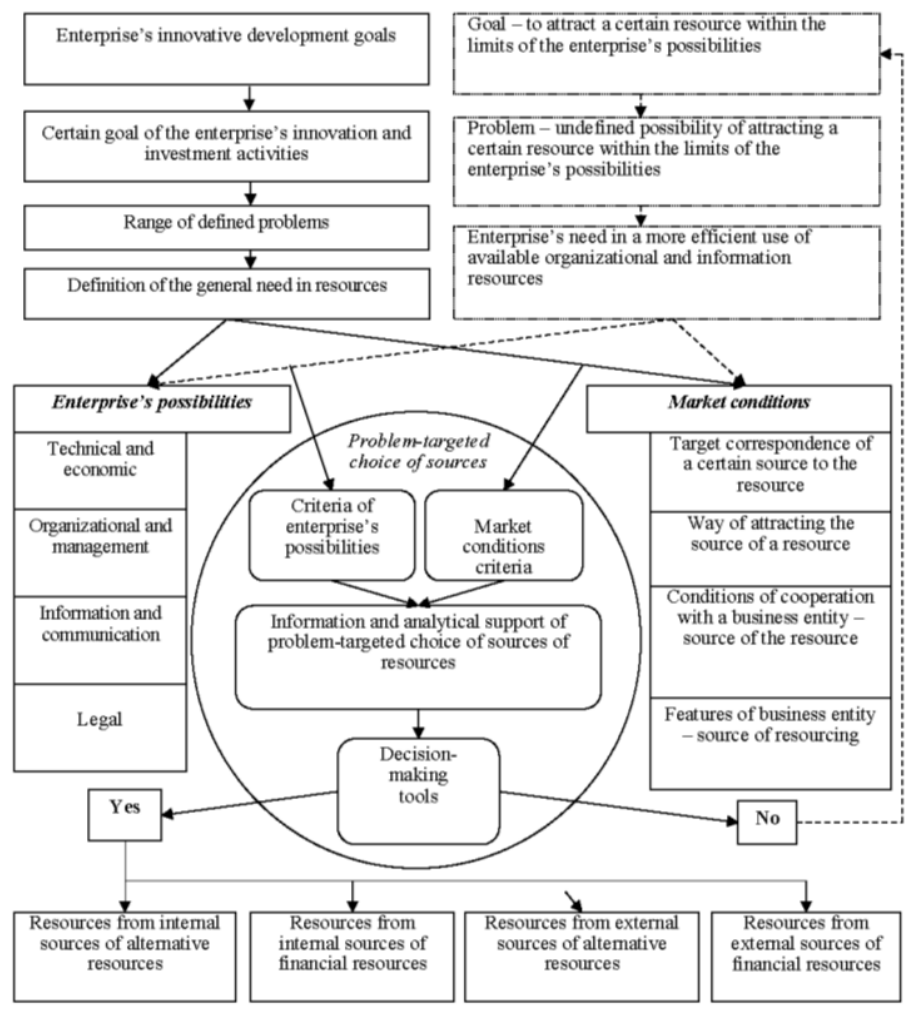

\section{Fig. 2. A full conceptual model of problem-targeted differentiated choice of resourcing sources}

The scientific and analytical approach to administering the operational activities of enterprises participating in the system of investment support of residential construction constitutes the essence of the analytical technology and tools for accommodating the contents and order of the processes of investment support of residential housing with the productivity of the operational activities of enterprises (developers) participating in the project, implemented and substantiated in this work.

The mentioned technology and tools are implemented through a system of the following structural and analytical components integrated into a single formalized decision-making system:

- the first component (component A) in the implemented technology is an economical, managerial, structural and hierarchical model "Economic, administrative and structural topology of interaction between enterprises 
participating in a housing construction project" which proposes alternative variants of economic and managerial interaction between participating enterprises during the cycle of creating value of a residential construction project;

- the next component (component B) within the implemented technology is an economic, structural and analytical model "Structuring of the contents, order and budget of investment into residential construction by participating enterprises";

- the final component (component C) - a model titled "Investment $\rightarrow$ project $\rightarrow$ participating enterprise» within the presented approach formally reflects the impact of the rates of a project's investment support and its economic and administrative environment on the functional and economic performance of certain enterprises participating in the project and their liquidity and solvency level.

\section{Investment determinants in the context of sustainable development: tactical and strategic aspects}

At the current development stage of the construction sphere, the synergetic basis of the elements of the processes of construction organization and management is increasing significantly. Virtually no significant investment and construction project is realized today without a collaborative component on the level of management, resource and information interaction between the processes of project development and construction, their document, regulatory and technical and technological support. In this sense, there is a necessity to build a system to form innovative competency in the field of system engineering, economics, construction organization and management. Overall, today construction management is improving towards the development of organizational systems formalizing business processes and forming consistent contractual relationships, which becomes a decisive factor of innovative development on the level of investors and building contractors. Multidimensional project management systems integrated with the systems of modelling and managing the life cycle of objects of a new level will allow to ensure the necessary quality of the object and process analysis and managerial decisions, including the deployment of cost management, construction terms, investment and project risks. Introduction of project management on the basis of modern information models has to facilitate the fulfilment of the innovative development of the construction sphere.

Within the sustainable development concept, a new approach to projecting and constructing objects has emerged, which is called sustainable projecting. It allows integration, analysis and optimization of ecological, technological, social and economic factors at every stage of the projecting process, a wide use of energy-saving technologies and renewable resources, including a closed circle of resource consumption, a harmonious inclusion of 
a new house into the environment and many more aspects which have to minimize the negative influence of human activity on the environment.

If the laws of interaction between the society and the nature are not taken account of properly, urban development entails significant (anthropogenic and technogenic) impact on the natural environment, which threatens catastrophic ramifications for biosphere and humans. Based on the results of the analysis, a conclusion is made on the necessity to accept a new urban development policy and introduce biosphere-compatible technologies in the construction and reconstruction of urban facilities.

The intensification of anthropogenic influence on the environment, coupled with the depletion of its assimilation potential, utter exacerbation of ecological problems in the conditions of depletion of non-renewable fuel and energy resources compels many researches to speak about the imminent ecological and humanitarian catastrophe ${ }^{56}$.

Investment and construction sector is one of the largest consumers of energy resources forming human environment. Therefore, it is necessary to organize such system for functioning of enterprises of territorial investment and construction sector, which will ensure that the development of construction, including residential construction, will be premised on the comparison of its human influence on nature (considering the balance of needs and possibilities of construction enterprises, developers and contractors) and environment sustainability with their influence. The implementation of such conceptual approach requires a transformation of the economic activities of the enterprises of investment and construction sphere into a new quality, achieving which will allow the implementation of innovative managerial solutions in construction of the objects of residential real estate will ensure the minimal consumption of natural resources, above all, thermal and energy resources.

The mentioned problems may be solved when the construction industry embraces the Green Building concept ${ }^{7}$. There are three main principles of ecoobjects: sustainable use of renewable resources (energy, water, land), assessment and minimization of the real estate item's negative impact on the environment at all its life cycle stages (in contrast to the existing focused normative approach to the evaluation of a construction's ecological safety at the design and construction stages only) and creation of a comfortable

${ }^{5}$ Econometric tools for managing construction companies' financial security [Text] : [monograph] / [L.V. Sorokina et al.]; under scientific supervision of professors Sorokina L.V. and Hoiko A.F. - Kyiv : Kyiv National University of Construction and Architecture, 2017. -403 pp.

${ }^{6}$ Theoretical and methodological framework of innovative and investment activities in Ukraine. / P.M. Kulikov, V.H. Fedorenko, H.M. Ryzhakova et al., collective monograph, LLC "DKS Center", Kyiv 2018. 442 pp.

${ }^{7}$ «Green Building -US EPA». Access mode: www.epa.gov 
"developing", environment for humans through the introduction of "green" standards.

According to the international standard ISO 26000:2010, sustainable development is the development that meets the needs of the present without compromising the ability of future generations to meet their own needs ${ }^{9}$. Sustainable development is about integrating the goals of a high quality of life, health and prosperity with social justice and maintaining the earth's capacity to support life in all its diversity. These social, economic and environmental goals are interdependent and mutually reinforcing. Sustainable development can be treated as a way of expressing the broader expectations of society as a whole. In this context, the implementation of the Smart City approach becomes the tool which can be introduced to improve people's quality of life and enhance the system of urban management and a city's sustainable development. A city may be considered smart, if investments into human and social capital, as well as into traditional (transport) and modern communication structure create the basis for sustainable economic development and high quality of life, with smart natural resource management thanks to grassroots governance.

According to the European smart city $\operatorname{model}^{8}$, smart cities are defined by six basic criteria/characteristics: 1) smart economy; 2) smart mobility; 3) smart environment; 4) smart people; 5) smart living; 6) smart governance. All these criteria correspond to the traditional urban development theories and are based on the widely accepted principles of regional competitiveness, transport and information and communication technologies, economics, natural resources, human and social capital, quality of life, as well as citizens' participation in urban management. For this reason, they were used as a basis of the 2007 rating, where 31 factor and 74 indicators correspond to the mentioned six characteristics ${ }^{10}$.

A previous analysis demonstrated that the division into categories and criteria of the analogs of the developed rating system for environmental friendliness and energy efficiency of houses in other countries is different. For example, BREEAM (Great Britain) - 9 categories and 48 criteria, DGNB (Germany) - 6 categories and 59 criteria, "Zelenyie Standarty" ("Green Standards") (Russia) - 10 categories and 46 criteria etc. This difference in the quantity (and, accordingly, in the contents) can be put down to the specific functions which have to be provided by the certification system and which depend on the existent climatic, resource, social and

\footnotetext{
${ }^{8}$ The smart city model. - Access mode: http://www.smartcities.eu/model.html

${ }^{9}$ ISO 26000 Guidance on social responsibility. Access mode: https://www.webcitation.org /672NbkWPg?url =htt p: //isotc .iso.org/static/

${ }^{10}$ Pokolenko V.O. Introducing the tools for choosing the alternatives of construction project implementation by functional and technical integrity of implementing organizations / Pokolenko V.O., Ryzhakova G. M., Prykhodko D.O. // Management of complex systems development. 2014. - Issue 19. - pp.104-108.
} 
cultural, economic conditions, regulatory and scientific and technical achievements of the country which developed the rating.

A formalized model of the dynamics of the state of biosphere-compatible urbanized territories in general is described by the following nonlinear equation:

$$
\frac{d x_{i}}{d t}=f_{i}\left(x_{1}, x_{2}, \ldots, x_{n}\right), i=1, n,
$$

where $f_{i}$ is continuous or sectionally continuous functions;

$x_{i}$ - coordinates of the system reflecting the state of a certain point on the phase plane or in the coordinate space and characterizing the state of the system's components at any moment in time.

As an evaluation criterion for the balance of biosphere-compatible urbanized territories, the quantitative ratio between its constituents' condition indicators, i.e.:

- the level of satisfaction of the needs in natural resources (so-called primary needs - water, oxygen, air, mineral raw materials etc.);

- the level of innovative development of infrastructure component in cities and settlements;

- the level of human potential development.

Mathematical representation of a dynamic system is determined by a set of non-linear differential equations:

$$
\left\{\begin{array}{l}
\dot{X}_{1}=a_{10} X_{1}-a_{11} X_{1}^{2}+\gamma_{1} X_{2} X_{3}-b_{1} Y+U_{10} \\
\dot{X}_{2}=a_{20} X_{2}-a_{22} X_{2}^{2}+\gamma_{2} X_{1} X_{3}-b_{2} Y+U_{20} \\
\dot{X}_{3}=a_{30} X_{3}-a_{33} X_{3}^{2}+\gamma_{3} X_{1} X_{2}-b_{3} Y+U_{30} \\
\dot{Y}=a_{40}-a_{44} Y^{2}+X_{1} X_{2} X_{3},
\end{array}\right.
$$

where $X_{1}$ is a variable characterizing the degree of natural resource consumption and the level of environment pollution by waste;

$X_{2}$ is a variable characterizing the level of development of manufacture and infrastructure component in the regions (the use of "green" technologies, number of innovative production facilities, rates of fixed asset renewal etc.);

$X_{3}$ is a variable characterizing the level of satisfaction of rational lifesupporting needs of urban populations (work, dwelling, education, healthcare, transportation etc.);

$Y$ is a variable presenting, on the system level, vital processes taking place simultaneously (synergy effect); 
$U_{10}, U_{20}, U_{30}$ are variables characterizing controlling actions directed at achieving the target state - compatibility with biosphere and progressive development of urbanized territories;

$a_{10}, a_{20}, a_{30}, a_{40}$ are feedback coefficients characterizing the influence of various environmental factors;

$a_{11}, a_{22}, a_{33}, a_{44}$ are feedback coefficients characterizing the stabilizing influence of external factors on the implementation of biosphere-compatible construction (e.g., the amount of anthropogenic and household waste recycled by an innovative, environmentally safe production and infrastructure component, has the effect of compensation of the adverse impact of a respective component on the environment)

$\gamma_{1}, \gamma_{2}, \gamma_{3}$ are coefficients characterizing the mutual influence between separate components and the elements of natural and sociological structures (indirect influence of air and water pollution level and other constituents of life sustenance on urbanized territories on population's health etc.);

$b_{1}, b_{2}, b_{3}$ are coefficients characterizing environment's stabilizing influence caused, for instance, by changes in legal framework, demographic processes, population's migration etc.

In Ukraine, the end-to-end maintenance of an investment and construction project, starting from the design stage up to the commissioning of the project, was novel until recently. However, this kind of management allows to predict, at various stages, the economic effects of general decisions taken at early and further stages of investment projects and to choose the efficient variant of project management and to timely correct its individual components to maximize the effect.

A changeover to project-oriented organizations is a global trend of the global community development caused by the fact that the technical and technological complexity of new products rises exponentially, life cycles shorten, but the expected value has to remain. This trend gives rise to conflicting demands and criteria for evaluating the projects concerning the creation of new products and services. Under such conditions, special significance is given to innovative mechanisms of project and program management based on convergence of knowledge and its system integration. The economic system of an enterprise is a complex integrated entity of spatially located elements, whose development is only possible provided that various kinds of production factors (material, technical, energy, labor, financial, and information) are optimally combined. At the current stage, special attention should be paid to the latter, as they ensure the efficient management of the use of other factors.

The rationale for an organization development project implementation should be based on the results of analysis of financial and operational activities (by main groups of indicators: financial, production, technological, economic etc.), market analysis (environment analysis: competitors, industry, consumers, market segment), analysis of efficiency of project proposals to be implemented 
(expenditures/payback period/development project profit: fixed asset acquisition, new production technology, separate production equipment units, marketing innovations, manufacture of new kinds of products, development of new kinds of activities, staff development etc.).

Based on the results of such analysis, the feasibility of implementation of the chosen development project is either confirmed or dismissed. In the case when the justification of a project's feasibility is incomplete of negative, the decision on development project implementation is cancelled.

In the second block, at the approval stage, investor is persuaded to invest money in the chosen development project. The enterprise's management exerts reflexive influence when it appeals to the investor's personal experience, which is substantiated by estimates. Table 1 contains details of reflexive strategies as an instrument of attracting investments for development projects for industrial enterprises.

The third block in the described approach is a practical one and foresees distribution of funds for development project investment and generating financial reports for the investor to consolidate the contact established at the previous stage.

Table 1

Behavior strategies of investment participants

\begin{tabular}{|c|c|c|c|}
\hline №1 & Participants & $\begin{array}{c}\text { Gains from investment } \\
\text { into a development } \\
\text { project }\end{array}$ & $\begin{array}{l}\text { Holding back from } \\
\text { investment into a } \\
\text { development project }\end{array}$ \\
\hline 1. & Investor № 1 & \multirow{2}{*}{$\begin{array}{c}\text { Profit-making, acquiring } \\
\text { positive experience }\end{array}$} & \multirow{2}{*}{ Loss of money } \\
\hline 2. & Investor № 2 & & \\
\hline 3. & Investor № 3 & $\begin{array}{l}\text { Profit-making, acquiring } \\
\text { positive experience }\end{array}$ & $\begin{array}{l}\text { Loss of money, risk of being } \\
\text { excluded from investment into } \\
\text { future potential projects by two } \\
\text { other investors }\end{array}$ \\
\hline 4. & $\begin{array}{l}\text { Construction } \\
\text { enterprise } \\
\text { management }\end{array}$ & $\begin{array}{l}\text { Improving competitiveness, } \\
\text { acquiring bonuses, } \\
\text { expansion of activities and } \\
\text { responsibilities }\end{array}$ & $\begin{array}{l}\text { Risk of being fired, loss of } \\
\text { investor's trust }\end{array}$ \\
\hline \multicolumn{4}{|c|}{ Investment object } \\
\hline 1. & $\begin{array}{c}\text { Project requiring } \\
\text { investment }\end{array}$ & Project is implemented & Project is not implemented \\
\hline 2. & $\begin{array}{l}\text { Construction } \\
\text { enterprise }\end{array}$ & $\begin{array}{c}\text { Getting effect from } \\
\text { development project } \\
\text { implementation, expansion } \\
\text { of activities, brand uprating }\end{array}$ & $\begin{array}{l}\text { Sale of enterprise in case of } \\
\text { failure of one or several } \\
\text { development projects due to } \\
\text { impossibility to bring the } \\
\text { enterprise on a totally new } \\
\text { development level. In this case, } \\
\text { sale is the optimum alternative } \\
\text { (while the brand retains its } \\
\text { positive impact) }\end{array}$ \\
\hline
\end{tabular}


The current operational environment construction enterprises find themselves in is characterized by a high agility and changeability of external and internal environment, globalization and transformation processes in the economy and the rising level of uncertainty and risk caused by these factors. This is why the organization of information collection systems at enterprises is very important to ensure that the processes on all levels of economic complex in the country and globally are overseen and managerial decisionmaking receives quality information support.

Today, such systems are built on the use of state-of-the-art information technologies, which allows to raise the response rate and other quality characteristics of information systems of modern enterprises. Increase in complexity and instability of economic processes lead to the change of the conditions of use of classical methods and approaches to the evaluation of information processes in place at enterprises, which necessitates the development and use of methodological approaches to their evaluation, as well as models and methods of analysis and forecasting their evolution dynamics, which allow to account for the uncertainty inherent to the process of modern economic systems development.

The real estate market in Ukraine had reach the development stage when construction organizations include into their business portfolio large projects which are technologically complex and financially intensive. As a rule, these projects deal with multifaceted objects, which make it possible for the enterprise to diversify the risks of the construction and try its hand in various segments of real estate. At the same time, multifaceted complexes are a very difficult format requiring a measured approach to the analysis, selection and distribution of functions, as miscalculations may influence the work's relevance and success.

\section{CONCLUSIONS}

It has been demonstrated that the analytical basis for forming an economic framework for investment mechanisms and provision of investment resources for real investments do not correspond to modern conditions of preparation and implementation of a residential construction cycle from its initial stage to commissioning of residential property complexes. This puts the need to renovate the methodological approach and tools of choosing economically sustainable economic and managerial mechanisms of residential construction and searching for sustainable variants of investment support for residential construction projects high on the agenda. It is noted that the modern features of work in a construction project require the office to act as a work coordinator for each separate project. It can be acknowledged that along with the complication of the nature of construction activities, classical symptoms of uncontrollability is 
observed at may construction enterprises: control over the launch, maintenance and development of projects is lost; managers' control over the operational activities of their structures weakens etc. In this regard, need arises to coordinate the managerial structure of a construction project in accordance with project management experience. On the basis of the proposed scientific and analytical approach to the administration of operational activities of the enterprises participating in the system of investment support of housing construction, comprehensive recommendations are developed aimed at differential attraction and evaluation of the sources of financial and alternative resources providing a wider range of possibilities to attract scarce resources than a functionally limited search of cash financing.

\section{SUMMARY}

The article is devoted to the development of scientific and methodological framework and tools for investment support of housing construction, which is considered in the context of mutual coordination with the specifics of economic and contractual relations of leading subjects of residential development - lender, developer, and investors. Methodological developments are based on the existing methodology of project management, the formation of a simplified and complete conceptual model of differentiated attraction of sources of resource support based on the theory of stakeholders, methods of economic assessment of sources of financing and attraction of investments and value-oriented goal-setting. The paper analyzes the existing concepts, models, methods of management of investment and construction projects, characterizes the current level of success of such projects. It was found that the housing project management system needs to be improved in terms of shifting the emphasis from maximizing the profit of builders to achieving the value of the project results for all its stakeholders throughout the life cycle of the project. The conceptual model of the problem-targeted differentiated choice of sources of resource support for investment and construction projects in housing construction is proposed.

\section{REFERENCES}

1. Econometric tools for managing construction companies' financial security [Text] : [monograph] / [L.V. Sorokina et al.]; under scientific supervision of professors Sorokina L.V. and Hoiko A.F. - Kyiv : Kyiv National University of Construction and Architecture, 2017. - 403 pp.

2. Theoretical and methodological framework of innovative and investment activities in Ukraine. / P.M. Kulikov, V.H. Fedorenko, 
H.M. Ryzhakova et al., collective monograph, LLC "DKS Center", Kyiv 2018. 442 pp.

3. Tetyana Marchuk, Dmytro Ryzhakov, Galyna Ryzhakova and Sergiy Stetsenko (2017). Identification of the basic elements of the innovative analytical platform for energy efficiency in project financing. Investment Management and Financial Innovations (open-access), 14(4), pp. 12-20. DOI: http://10.21511/imfi.14(4).2017.02

4. Pokolenko V.O. Introducing the tools for choosing the alternatives of construction project implementation by functional and technical integrity of implementing organizations / Pokolenko V.O., Ryzhakova G.M., Prykhodko D.O. // Management of complex systems development. - 2014. Issue 19. - pp.104-108.

5. Ryzhakova G.M. Models of targeted choice of representative performance indicators of construction companies: diagnostic systems etymology and typology / G.M. Ryzhakova, D.O. Prykhodko, K.M. Predun // Management of complex systems development. - 2017. Issue 32. - pp. 159-165.

6. Innovative development of an enterprise: textbook / V.G. Fedorenko, T.Ye. Voronkova, G.M. Ryzhakova; edited by V.G. Fedorenko, Kyiv, National University of Construction and Architecture, School of Economics of the National Academy of Sciences of Ukraine, V.G. Fedorenko, National Academy of Sciences of Ukraine, Kyiv : LLC "DKS Center", 2014 - 352 pp.

7. Chernyshev D. Formation of the methodical-analytical system of indicators of providing biosphere-compatibility at the preparation and organization of construction / D. Chernyshev // Management of complex systems development: Collection of scientific papers - Kyiv, KNUCA, 2018. - Issue 34 - pp. 191-198.

8. Chernyshev D. Implementation of principles of biospheric compatibility in the practice of ecological construction in Ukraine [Text] / D. Chernyshev, I. Ivakhnenko, G.Ryzhakova, K.Predun // International Journal of Engineering \& Technology - UAE: Science Publishing Corporation, 2018- Vol 10, No 3.2: Special Issue 2 - pp. 584-586.

9. Chupryna Y. The identification of alternatives and changes in scenarios for the development of regional build clusters [Text] / Y. Chupryna, D. Ryzhakov, O. Malykhina // International Journal of Engineering \& Technology - UAE: Science Publishing Corporation, 2018 Vol 10, No 3.2: Special Issue 2 - pp. 484-486.

10. Sharpe, W., Alexander, H., Bailey, J. Investments: translation from English. Moscow: INFRA-M, 2001. 1028 pp.

11. Residential housing financing schemes in Ukraine. Special features of attracting investments into construction [Electronic resource] // Materials of 
KLN Consult web-site // - Available at: http://www.kln.com.ua/content/ view/87/102/lang,ua

12. A.I. Rybak. Value-based management of investment and construction residential projects [Text] / A.I. Rybak, I.B. Azarova // Management of complex systems development. - 2013. - №24. - pp. 49 - 56.

13.Zeltser, R.Ya., Bielienkova, O.Yu, Novak, Ye.V., Dubinin, D.V. Digital Transformation of Resource Logistics and Organizational and Structural Support of Construction [Text] / Zeltser, R.Ya., Bielienkova, O.Yu, Novak, Ye.V., Dubinin, D.V. // Science and Innovation, 2019 Vol. 15(5) - pp. 38-51.

14. Izmailova K.V. The essence of economic cycles and their impact on the financial stability of construction [Text] / Izmailova K.V., Bielienkova O.Yu, Moholivets A.A. // Nauk. pr. NDFI, 2019 - Vol. 2 pp. 139-150.

15. Stetsenko S. The hierarchical model of evaluation of infrastructure risks / S. Stetsenko, T. Ilyina // Nauk. pr. NDFI, 2019. - Vol. 1. pp. 119-129.

16.Zeltser, R.Ya., Bielienkova, O.Yu. and Dubinin, D.V. 2018) Innovatsiini modeli i metody orhanizatsii, upravlinnia i ekonomichnoi otsinky tekhnolohichnykh protsesiv budivelnoho vyrobnytstva Kyiv: «MP Lesia», 2019 - 209 p.

17. Maksimov, A.S. Vakhovich, I.V. and other (2015), Enerhoefektyvnist' $\mathrm{v}$ munitsypal'nomu sektori [Energy efficiency in the municipal sector], Association of Ukrainian Cities under the USAID Project, Kyiv, Ukraine», 2015 - 254 p.

\section{Information about the author: Ryzhakova G. M.,}

Doctor of Economics, Professor, Head of Construction Management Department, Kyiv National University of Construction and Architecture 31, Povitroflotsky Avenue Kyiv, 03037, Ukraine 


\section{THE EFFECT OF THE BUSINESS ACTIVITY ON THE CONCENTRATION OF NEW CONSTRUCTION REAL ESTATE MARKETS}

\section{Bielienkova O. Yu.}

\section{INTRODUCTION}

The real estate development is one of the key sectors of the economy of any country; it acts as a driving force at growth of economy, though along with that its response on downturn in economic activity is stronger compared to the other sectors.

In Ukraine, the construction industry is stagnant. For the fifth consecutive year, demand at the new construction real estate markets in all the regions is under pressure of adverse macroeconomic situation that has a negative effect on the volumes of housing sales and makes a fall in prices. In predicting the tendencies of the further market development, the opinions of developers have diverged in the opposite directions, namely: some analysts believe that there is to be no further decrease in the real estate prices, since the market has reached the "bottom", and some - that the price decrease is to continue $^{1}$. In order to objectively evaluate the forecasts of developers, their ability to influence the market conditions, it is necessary to analyze the level of competition in the market of new buildings and the degree of effect of individual firms on its development.

Competition is a key feature of market economy, its essential component and a prerequisite for its functioning and development. A developed competitive environment is not only the basis for the development of new opportunities to gain competitive advantages, development of strategies of individual market players, but is also the process of development of economic systems. At that, the competitive environment includes not only the direct participants of the construction market, but also all the stakeholders who, acting to meet their own needs, influence the market structure, generating supply and demand, forming expenditures of participants, etc.

At evaluation of competition in the construction markets, several approaches are used to analyze the behavior of individual companies and the

\footnotetext{
${ }^{1}$ Ukrainian developers predict increase in housing prices in $2016 / /$ [Electronic source] Access mode: http://ua.korrespondent. net/ business /realestate/3615553-ukrainskizabudovnyky-prohnozuuit-podorozhchannia -zhytla-v-2016-rotsi
} 
effectiveness of methods of state regulation of markets, based on the concept of the Harvard Business School "structure-behavior-result"2. At that the indicators for competition valuation are also divided into three groups, namely: structure indicators (market concentration coefficients, HerfindahlHirschman index, Gini index, etc.), company behavior indicators (it is most difficult to estimate those by formalized methods, assessment of the market entry and exit barriers, decisions on expansion or reduction of investments, etc. is used), performance indicators (Lerner index, prices, sales volume, financial results of companies at the market, etc).

An overview of the competitive environment of the construction markets of Ukrainian regions and the analysis of the effect of business activity on the market concentration will help to find out whether the investment activity, employment, number of economically active enterprises and other indicators affect the competition for individual markets.

Without diminishing the benefits of application of the behavioral indicators and the outcome indicators, we analyze the competition in the new construction housing market of the Kyiv city and the regions of Ukraine from the standpoint of the structural approach according to the method described in detail in ${ }^{3}$.

To the problems of the market structure analysis the works of the following scientists are devoted: A. Burian, V. Gerasimenko, O. Miniailo, Yu. Onishchenko, T. Tsyhan, V. Chirkova and others. In their research, they analyze the structural features of the markets by concentration indices representing the tendencies of development depending on changes in the number and sizes of the enterprises in the goods or services production market.

Despite the large number of scientific papers devoted to market concentration studies, insufficient attention is paid in the economic literature to the quantitative assessment of the market concentration for real estate developer enterprises operating in residential real estate markets.

Recently, attention of scientists to concentration at construction markets has increased. So, the regional peculiarities of competitive environment are examined by Pavlov K.V., Gritsenko O.S, Zapechna Yu.O., Tsifra T.Yu., Lysak I.V., Sorokina L.V. Such an analysis is traditionally carried out by means of concentration indices, and thus the problem of reviewing the most common indicators of market concentration

\footnotetext{
${ }^{2}$ Bain, J. (1954). Economies of Scale, Concentration, and the Condition of Entry in Twenty Manufacturing Industries. American Economic Review, 44(1), 15-39.

3 Bielienkova O.Yu., Tsifra T.Yu., Tsariuk T.M. Assessment of the processes of concentration and consolidation of banking capital in the CIS states and in the world. Ways of improving the efficiency of construction under conditions of formation of market relations .: Coll. scientific works. - issue.23. -2012 . - P.9 -13
} 
assessment, of identifying their shortcomings and advantages and selecting the ones most suitable for research purposes is considered to be a question of present interest.

\section{Assessment of concentration}

of the new construction housing markets in Ukrainian regions

Assessment of market concentration is carried out with the purpose of the ability of individual enterprises operating in the market to influence the market situation, for investigation of the market structure, for reveal of the largest by volumes of sales, by the work performed participants, this is the basis for tracking and analyzing their behavior, strategies, dynamics of development and more.

Indicators of concentration for developer enterprises operating at the new construction housing market reflect the number of firms and the volumes of construction and sales of residential estate compared to the market volume. With the smaller number of developers, higher is the level of concentration, greater the possible effect each individual enterprise can make on formation of housing prices.

To analyze the market concentration, following indicators have become the most widely used: the concentration index, the Herfindahl-Hirschman index, the Gini index ${ }^{4}$.

Concentration index. The small amount of input data needed and the ease of calculation have contributed to the fact that the market concentration index is nowadays the most widespread one of the indicators named above.

$$
C R_{k}=\sum_{i=1}^{k} s_{i}
$$

where $C R_{k}$ - concentration index;

$\boldsymbol{S}_{\boldsymbol{i}}$ - share of the i-th enterprise in the market;

$k$ - number of largest enterprises.

This indicator makes it possible to calculate the market concentration by volumes of work, or by the volumes of assets of the largest developers, while ignoring the results of activity of the small and medium market participants. If the value of this index is close to 100. the market is

${ }^{4}$ Grytsenko O. S. Evaluation of concentration of new construction real estate market of Donetsk region / O.S. Grytsenko, Yu.S. Zapiechna, I.V. Lysak // Control of complex system development. - 2017. - Issue. 32. - P. 110-113. 
characterized by a high degree of monopolization, and if it approaches zero, the market is evaluated as a competitive one ${ }^{5}$.

For the market analysis in practice, concentration levels of the three (five, seven) largest business entities are used. These are the so-called concentration ratios CR-3, CR-5, CR-7, depending on the number of the largest participants. The disadvantage of this indicator is the lack of accounting for all the business entities operating in the market, since for the objective analysis of the competitive environment the total number of entities on which the remaining volume of the market being analyzed rests may be relevant.

It is possible to overcome this shortcoming by means of application of the Herfindahl-Hirschman Market Concentration Index (HHI) that takes into account the total number of enterprises operating in a given market. This index is suggested for application in the market concentration analysis by the American economist and Justice Department employee William Baxter, and today it is one of the most widespread indicators used to analyze the market concentration.

The Herfindahl-Hirschman Market Concentration Index shows the share of small businesses in a given market. The HHI is calculated as the sum of the squares of shares (given in percent) of each one of the enterprises operating in the market. The value of this index is determined as the sum of market share squares in the market structure attributable to each enterprise ${ }^{6}$ :

$$
H H I=\sum_{i=1}^{n} s_{i}^{2}
$$

where $H H I$ is the Herfindahl-Hirschman index;

$\boldsymbol{s}_{\boldsymbol{i}}$ - share of the i-th enterprise in the market;

$\mathrm{n}$ - number of enterprises in the market.

The Herfindahl-Hirschman index proves the importance of the large enterprises, with assigning larger specific weight to those compared to the smaller ones, and is quite sensitive to the entrance of new businesses to the market. This index becomes less sensitive to changes with increase of the number of enterprises in the market. The index is easy to calculate because it does not depend on the market volume as a whole, but reflects the change in

\footnotetext{
5 Tsykhan T.V. Theoretical bases of control of economic concentration // www.jurenergo.kiev.ua/statti/osncontr.doc

${ }^{6}$ Chyrkov Volodymyr. Market Concentration Indicators [Electronic source] - Access mode: http://www.kmu.gov.ua/amc/control/uk/publish/article?showHidden=1\&art_id $=4940$ 8\&cat_id=47049\&ctime $=1202372165628$
} 
the market share of the smallest or the largest enterprise. This index is a function decreasing with the increase in the number of enterprises in the relevant market in the case of uneven distribution of market shares ${ }^{7}$.

The market is considered to be unconcentrated if $\mathrm{HHI}<0.1$; moderately concentrated if $\mathrm{HHI}<0.18$; and highly concentrated if $\mathrm{HHI}>0.18$.

Gini Index ${ }^{8}$

$$
\text { ДЖ }=1-\frac{A}{0,5}
$$

where ДЖ is the Gini index;

0.5 - the value of the area of the triangle bounded by the Lorenz curve with uniform distribution of particles and the axes of abscissa and ordinate.

$\mathrm{A}$ - the area bounded by the actual Lorenz curve and the axes of abscissa and ordinate.

The Gini index, compiled on the basis of the Lorenz curve, expresses the nonuniformity of distribution for any characteristic, in this case - of the market shares. The higher the Gini index is, higher is the nonuniformity of market share distribution among the market participants and, therefore, higher is the market concentration and its monopolization.

For determination of the market concentration indices, the data from the website http://zabudovnyk.com.ua/ ${ }^{9}$ which generates information about objects being built in Ukraine are used.

According to the materials of the website for the years 2018-19, the data on construction of objects for Vinnytsia, Chernihiv, Cherkasy, Volyn, Kherson, Zakarpattia, Sumy, Poltava, Mykolaiv, Ternopil, Kharkiv, Rivne, Khmelnytsky, Zhytomyr, Ivano-Frankivsk regions and Kyiv city and the developer companies involved in the construction of those objects (Table 1) are selected for analysis.

In 2019, the majority of developers and residential objects are concentrated in Kyiv city, this is consistent with statistical reports according to which more than $30 \%$ of newly built housing is located in Kyiv city. Among the analyzed regions, the least number of companies are engaged in construction in the Mykolaiv, Kherson, Sumy and Cherkasy regions.

${ }^{7}$ Gerasimenko V. Banking Capital Concentration and Methods of Assessing its Level. // Bulletin of the National Bank of Ukraine - 2007. - No. 4 - P. 28-32.

${ }^{8}$ Chyrkov Volodymyr. Market Concentration Indicators [Electronic source] - Access mode: http://www.kmu.gov.ua/amc/control/uk/ publish/ article?show Hidden=1\&art_id $=49408 \&$ cat_id $=47049 \&$ ctime $=1202372165628$

${ }^{9}$ Kyiv and Ukrainian Developers // New Buildings of Kyiv and Ukraine // [Electronic source] - Access mode: https://zabudovnyk.com.ua/uk/developers/region/all 
For estimation of the concentration levels of the markets, the concentration index, Herfindahl-Hirschman and Gini indices are chosen as being widespread and fairly simple to calculate. These indices are calculated for two arrays - the number of objects and the total area of housing for sale (Table 2-4).

Table 1

Number of the objects for sale and the developers in different regions of Ukraine

\begin{tabular}{|c|c|c|c|}
\hline No. & Region & Developer number & Object number \\
\hline 1 & Vinnytsia & 15 & 25 \\
\hline 2 & Volyn & 10 & 33 \\
\hline 3 & Zhytomyr & 13 & 15 \\
\hline 4 & Zakarpattia & 7 & 18 \\
\hline 5 & Ivano-Frankivsk & 19 & 51 \\
\hline 6 & Mykolaiv & 5 & 10 \\
\hline 7 & Poltava & 10 & 34 \\
\hline 8 & Rivne & 13 & 27 \\
\hline 9 & Sumy & 4 & 16 \\
\hline 10 & Ternopil & 10 & 40 \\
\hline 11 & Kharkiv & 12 & 48 \\
\hline 12 & Kherson & 6 & 7 \\
\hline 13 & Khmelnytsky & 14 & 44 \\
\hline 14 & Cherkasy & 4 & 8 \\
\hline 15 & Chernihiv & 8 & 38 \\
\hline 16 & Kyiv city & 90 & 423 \\
\hline
\end{tabular}

Table 2

Results of calculation of the CR-3, CR-5, CR-7 indices for the housing development markets for different regions of Ukraine

\begin{tabular}{|c|c|c|c|c|c|c|c|}
\hline \multirow{2}{*}{ No. } & \multirow{2}{*}{ Region } & \multicolumn{6}{|c|}{ Concentration index } \\
\cline { 3 - 8 } & & \multicolumn{2}{|c|}{ CR-5 } & \multicolumn{2}{c|}{ CR-7 } \\
\hline & & By objects & By area & By objects & By area & By objects & By area \\
\hline 1 & Vinnytsia & 0.4 & 0.47 & 0.56 & 0.66 & 0.68 & 0.77 \\
\hline 2 & Volyn & 0.58 & 0.66 & 0.76 & 0.85 & 0.88 & 0.93 \\
\hline 3 & Zhytomyr & 0.33 & 0.46 & 0.47 & 0.67 & 0.6 & 0.81 \\
\hline 4 & Zakarpattia & 0.67 & 0.75 & 0.89 & 0.92 & 1 & 1 \\
\hline 5 & Ivano-Frankivsk & 0.39 & 0.42 & 0.55 & 0.65 & 0.69 & 0.75 \\
\hline 6 & Mykolaiv & 0.8 & 0.63 & 1 & 1 & 1 & 1 \\
\hline 7 & Poltava & 0.74 & 0.71 & 0.85 & 0.85 & 0.91 & 0.91 \\
\hline 8 & Rivne & 0.52 & 0.68 & 0.67 & 0.88 & 0.78 & 0.94 \\
\hline 9 & Sumy & 0.84 & 0.75 & 1 & 1 & 1 & 1 \\
\hline 10 & Ternopil & 0.59 & 0.65 & 0.8 & 0.83 & 0.9 & 0.93 \\
\hline 11 & Kharkiv & 0.54 & 0.58 & 0.77 & 0.8 & 0.87 & 0.9 \\
\hline 12 & Kherson & 0.57 & 0.76 & 0.86 & 0.93 & 1 & 1 \\
\hline 13 & Khmelnytsky & 0.46 & 0.52 & 0.61 & 0.72 & 0.75 & 0.84 \\
\hline 14 & Cherkasy & 0.91 & 0.96 & 1 & 1 & 1 & 1 \\
\hline 15 & Chernihiv & 0.63 & 0.82 & 0.87 & 0.96 & 0.97 & 0.99 \\
\hline 16 & Kyiv city & 0.2 & 0.28 & 0.27 & 0.36 & 0.33 & 0.43 \\
\hline
\end{tabular}


The concentration indicators shown in the Table 2 indicate a low level of concentration of the new construction real estate market in Kyiv city and the region. This leads to the conclusion that there is competition in the housing development sector. That is, none of the developers analyzed is large enough to be able to go against the market and dictate its own pricing conditions. Under such circumstances, the market presents differentiated products, with lax control of prices largely depending on market conditions. The other regions have moderate levels of concentration.

Table 3

\section{Results of calculation of the Herfindahl-Hirschman indices for the housing development markets for different regions of Ukraine}

\begin{tabular}{|c|c|c|c|}
\hline \multirow{2}{*}{ No. } & \multirow{2}{*}{ Region } & \multicolumn{2}{|c|}{ HHI } \\
\cline { 2 - 4 } & & Number of objects & Housing area \\
\hline 1 & Vinnytsia & 0.094 & 0.1 \\
\hline 2 & Volyn & 0.146 & 0.178 \\
\hline 3 & Zhytomyr & 0.084 & 0.1 \\
\hline 4 & Zakarpattia & 0.204 & 0.242 \\
\hline 5 & Ivano-Frankivsk & 0.094 & 0.172 \\
\hline 6 & Mykolaiv & 0.32 & 0.201 \\
\hline 7 & Poltava & 0.216 & 0.21 \\
\hline 8 & Rivne & 0.127 & 0.189 \\
\hline 9 & Sumy & 0.302 & 0.221 \\
\hline 10 & Ternopil & 0.049 & 0.164 \\
\hline 11 & Kharkiv & 0.139 & 0.155 \\
\hline 12 & Kherson & 0.18 & 0.227 \\
\hline 13 & Khmelnytsky & 0.106 & 0.126 \\
\hline 14 & Cherkasy & 0.344 & 0.546 \\
\hline 15 & Chernihiv & 0.194 & 0.339 \\
\hline 16 & Kyiv city & 0.026 & 0.002 \\
\hline
\end{tabular}

The market is considered to be unconcentrated if $\mathrm{HHI}<0.1$; moderately concentrated if $\mathrm{HHI}<0.18$; and highly concentrated if $\mathrm{HHI}>0.18$.

Thus, the markets of Kyiv city, Vinnytsia and Zhytomyr regions are unconcentrated. Highly concentrated are the markets of Cherkasy, Chernihiv, Sumy, Poltava, Mykolaiv, Zakarpattia regions. Other regions of Ukraine have a moderate level of concentration. The shortcoming of the HHI indicator is that it is highly dependent on the number of firms that are present in the sample and on their size. Therefore, in the case of its application for the markets with few businesses inaccuracies are possible. As the number of firms in the sample changes, concentration indices change as well. Additional data collection should be performed to confirm the calculations. It can be so that developers in these regions do not sell real estate through the Internet in all the property units, and that's why there are so few real estate units in the databases. In the other regions, the market is 
moderately concentrated, this is most commonly found in construction markets. Perfect competition, as well as the monopoly position of one developer, is not very common.

The Gini index takes values within the range from 0 to 1 . With the higher Gini index higher is the nonuniformity of market share distribution among the sellers and, therefore, all else being equal, higher is the market concentration (Table 4).

Table 4

Results of calculation of the Gini indices for the housing development markets for different regions of Ukraine

\begin{tabular}{|c|c|c|c|}
\hline \multirow{2}{*}{ No. } & \multirow{2}{*}{ Region } & \multicolumn{2}{|c|}{ GI } \\
\cline { 2 - 4 } & & Number of objects & Housing area \\
\hline 1 & Vinnytsia & 0.4 & 0.41 \\
\hline 2 & Volyn & 0.36 & 0.46 \\
\hline 3 & Zhytomyr & 0.11 & 0.36 \\
\hline 4 & Zakarpattia & 0.33 & 0.42 \\
\hline 5 & Ivano-Frankivsk & 0.47 & 0.43 \\
\hline 6 & Mykolaiv & 0.36 & 0.04 \\
\hline 7 & Poltava & 0.5 & 0.49 \\
\hline 8 & Rivne & 0.37 & 0.6 \\
\hline 9 & Sumy & 0.38 & 0.2 \\
\hline 10 & Ternopil & 0.42 & 0.47 \\
\hline 11 & Kharkiv & 0.44 & 0.49 \\
\hline 12 & Kherson & 0.12 & 0.32 \\
\hline 13 & Khmelnytsky & 0.42 & 0.49 \\
\hline 14 & Cherkasy & 0.55 & 0.63 \\
\hline 15 & Chernihiv & 0.38 & 0.60 \\
\hline 16 & Kyiv city & 0.50 & 0.60 \\
\hline
\end{tabular}

The disadvantage of this indicator is in the fact that it measures the relative sizes of firms only. Therefore, its value is the same for ten identical firms of the market and for one hundred, although it is obvious that the degree of competition for different numbers of enterprises is different. For example, for the Kyiv city market, where about 90 enterprises operate, the Gini index is the same as for the Chernihiv region (eight enterprises). Thus, for the most comprehensive view of the structure of the market, all concentration indicators are to be considered in combination, with account of their relationship.

One of the reasons for high concentration of the new construction housing market is the presence of high administrative, economic, technical, organizational barriers for market entry, those are reflected primarily in the high level of transaction expenses, during the period of entrance to a new market and during the periods of market development and further functioning in the market as well. Those barriers impede or significantly 
complicate entrance to the market for new business enterprises. Complex procedures for land acquisition, project appraisal and approval, for obtaining permitting documentation, town-planning and environmental restrictions, energy efficiency requirements for projects, significant risks, the need for high financial expenses before construction begins, etc. are the factors that impede market entry for new developers, increase market concentration. And economic development, growth of business activity, on the contrary, lead to increased competition which reduces the market concentration. Therefore, the hypothesis of the study is the assumption that business activity has a direct impact on the market concentration.

\section{Effect of business activity on concentration of the new construction housing markets in Ukrainian regions}

The term "business activity" is for long time till now used by many scientists and operating economists to characterize economic activity at the level of an individual enterprise, industry, region, and the entire economic system of the country. At that, a number of indicators are used to evaluate business activity.

Statistical data on the volume and dynamics of production, the number of large, medium and small enterprises, the number of employed, number of employed among the able-bodied population, number of part-time workers, etc., are widely used to measure business activity at the state level.

Along with the statistical information, there are disseminated surveys of experts, managers and employees of enterprises, an example of those is the Purchasing Managers' Expectation Index (PMI) calculated by the American association ISM (Institute for Supply Management, formerly - NAPM) ${ }^{10}$. This index is one of the economic indicators that show a high enough degree of accuracy in predicting growth of inflationary pressures and changes of the economic cycle phases. High accuracy of the index has led to the fact that own PMIs or similar indices are being calculated in many countries all over the world ${ }^{11}$.

Since 2013, the State Statistics Committee collects in Ukraine the data on expectations of enterprises regarding their business activity future development prospects. The heads of enterprises are surveyed on a quarterly basis by the following groups of economic activities: industry, construction,

10 ISM. "ISM Report On Business". instituteforsupplymanagement.org. https://www.instituteforsupplymanagement.org/news/content.cfm?ItemNumber=28965\&navIte mNumber $=28882 \& S S O=1$ July2019.zip (request date: 10.04 .19 )

11 "Singapore PMI". SIPMM Academy. https://sipmm.edu.sg/about-sipmmacademy/singapore-pmi/,Caixin China General Services PMI https://www.markiteconomics.com/public , PMI - Purchasing Manager https://www.silf.se/ medlem-i-silf/pmi-inkopschefsindex/,TANKAN http://www.boj.or.jp/en/statistics/tk/index.htm/ 
retail, services and agriculture. The research methodology is aligned with the recommendations for organizing and conducting enterprise business activity surveys outlined in the Joint Harmonized EU Programme of Business and Consumer Surveys ${ }^{12}$ and the OECD handbook on business activity surveys ${ }^{13}$. The research includes the results of expectations in the following areas: changes in production volumes, in prices for products, works, services, and the number of employees. Based on these data, the economic sentiment indicator is calculated ${ }^{14}$.

To estimate the levels of business activity in the regions of Ukraine, we use the indicators that, in our opinion, can characterize the business activity of construction at the level of individual regions or areas of the country, namely: disposable income per capita, migration growth (reduction), gross regional product, average monthly salary of one full-time employee, capital investments, housing stock, number of enterprises (Table 5).

For evaluation of the market concentration, the Herfindahl-Hirschman Index (HHI) is used. Since this index is calculated for not all the regions of Ukraine, hereinafter the effect of business activity on the market structure is studied only for the Vinnytsia, Chernihiv, Cherkasy, Volyn, Kherson, Zakarpattia, Sumy, Poltava, Mykolaiv, Ternopil, Kharkiv, Rivne, Khmelnytsky, Zhytomyr, Ivano-Frankivsk regions and the Kyiv city.

To estimate the degree of influence of the above indicators on market concentration, we use the determination coefficient $\left(\mathrm{R}^{2}\right)$ calculated as a measure of the dependence of the dependent variable variation on variation of independent variables and the mean linear error $(\bar{\Delta} \mathrm{j})$. The determination coefficient indicates how much the observations obtained are reproduced by the model, based on the fraction of the total deviation of the results that can be explained by the model. The higher the value of the coefficient $R^{2}$ is, the greater is the coverage.

\footnotetext{
${ }^{12}$ The Joint Harmonised EU Programme of Business and Consumer Surveys: User Guide. Brussels: European Commission, Directorate General for Economic and Financial Affairs, 2014

${ }^{13}$ Business Tendency Surveys: A Handbook. - Paris: OECD, 2003

14 Expectations of construction enterprises regarding their business activity future development prospects http://www.ukrstat.gov.ua/operativ/operativ2019/fin/rp/bud/ bud_I_2019.pdf
} 
Indicators of business activity for the regions of Ukraine

\begin{tabular}{|c|c|c|c|c|c|c|c|c|}
\hline & \multicolumn{7}{|c|}{ Indicator } \\
\hline & & 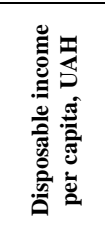 & 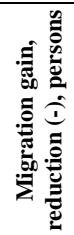 & 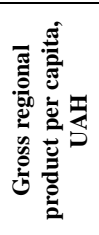 & 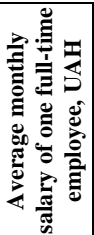 & 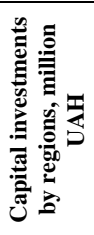 & 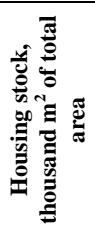 & 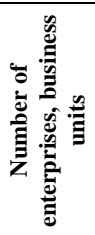 \\
\hline 1 & Vinnytsia & 54992 & -3842 & 58384 & 7801 & 17626.5 & 47621 & 9713 \\
\hline 2 & Volyn & 46475,1 & $\begin{array}{l}-687 \\
\end{array}$ & 49987 & 7324 & 8687 & 24362 & 5917 \\
\hline 3 & Dnipropetrivsk & $\begin{array}{l}72883.4 \\
\end{array}$ & 2552 & 97137 & 8862 & 60288.6 & 77297 & 29124 \\
\hline 4 & Donetsk & 31888 & -10280 & 39411 & 9686 & 26979.4 & 51539 & 9731 \\
\hline 5 & Zhytomyr & 52135.9 & -1431 & 49737 & 7372 & 8742.3 & 33791 & 6913 \\
\hline 6 & Zakarpattia & 40471.6 & 84 & 34202 & 8070 & 7500.6 & 31008 & 6425 \\
\hline 7 & Zaporizzhia & 67982.5 & -2172 & 75306 & 8726 & 15732 & 40925 & 14995 \\
\hline 8 & $\begin{array}{c}\text { Ivano- } \\
\text { Frankivsk } \\
\end{array}$ & 48367.7 & 560 & 46312 & 7551 & 9393.7 & 37027 & 8300 \\
\hline 9 & Kyiv & 63498.4 & 27142 & 90027 & 9097 & 40713.4 & 62756 & 20054 \\
\hline 10 & Kirovograd & 51018 & -2294 & 55183 & 7191 & 7181,5 & 25248 & 8068 \\
\hline 11 & Lugansk & 20618.6 & -5630 & 13883 & 7365 & 3219.3 & 18774 & 3449 \\
\hline 12 & Lviv & 55510.7 & 1886 & 58221 & 8001 & 28995.5 & 59192 & 19237 \\
\hline 13 & Mykolaiv & 55543.9 & -2213 & 60549 & 8160 & 10099.2 & 25744 & 11434 \\
\hline 14 & Odesa & 61165.6 & 7696 & 62701 & 8011 & 23787.8 & 56319 & 24707 \\
\hline 15 & Poltava & 60217.5 & 76 & 106248 & 8375 & 18636.7 & 36115 & 10959 \\
\hline 16 & Rivne & 47729.1 & -2198 & 42038 & 7469 & 7228 & 25893 & 5545 \\
\hline 17 & Sumy & 55934.4 & -2103 & 51419 & 7324 & 7749.9 & 28345 & 5949 \\
\hline 18 & Ternopil & 43512.5 & 35 & 38593 & 6969 & 8375 & 27744 & 5043 \\
\hline 19 & Kharkiv & $\begin{array}{l}60117.7 \\
\end{array}$ & 4534 & 69489 & 7657 & 23551.3 & 65116 & 23793 \\
\hline 20 & Kherson & $\begin{array}{l}50109.4 \\
\end{array}$ & -2273 & 45532 & 7058 & 8853,2 & 25039 & 8218 \\
\hline 21 & Khmelnytsky & 52487.6 & -666 & 49916 & 7346 & 11274,9 & 34896 & 7431 \\
\hline 22 & Cherkasy & 50292.6 & -2468 & 59697 & 7478 & 11110.4 & 34334 & 9176 \\
\hline 23 & Chernivtsi & 42850.4 & 222 & 31509 & 6991 & 3720.6 & 22448 & 4096 \\
\hline 24 & Chernihiv & 50895.4 & -1883 & 55198 & 6995 & 8971.3 & 29912 & 6107 \\
\hline 25 & Kyiv city & 141173.8 & 13942 & 238622 & 13542 & 200308 & 63388 & 91568 \\
\hline
\end{tabular}

The first indicator effect of which is investigated is the disposable income per capita (DIPC), million UAH ${ }^{15}$. As one can see from the Fig. 1, visually in the regions with higher income per capita there is a lower concentration of the market by the area of constructed housing (HHI), and vice versa, in the regions with lower income per capita, less housing is being built, there are fewer apartments for sale and, accordingly, concentration levels are lower. One can make an assumption that there is an inverse dependence of the HHI indicator on the DIPC characteristics (Fig. 2).

${ }^{15}$ Population income in region of Ukraine http://www.ukrstat.gov.ua/ 


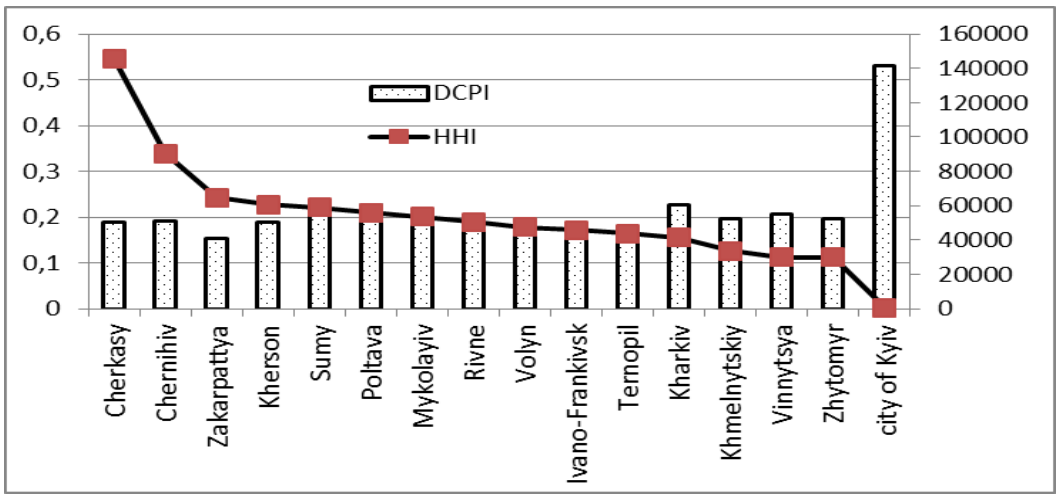

Fig. 1. The disposable income per capita (DIPC) and the Herfindahl-Hirschman indices (HHI) for different regions of Ukraine

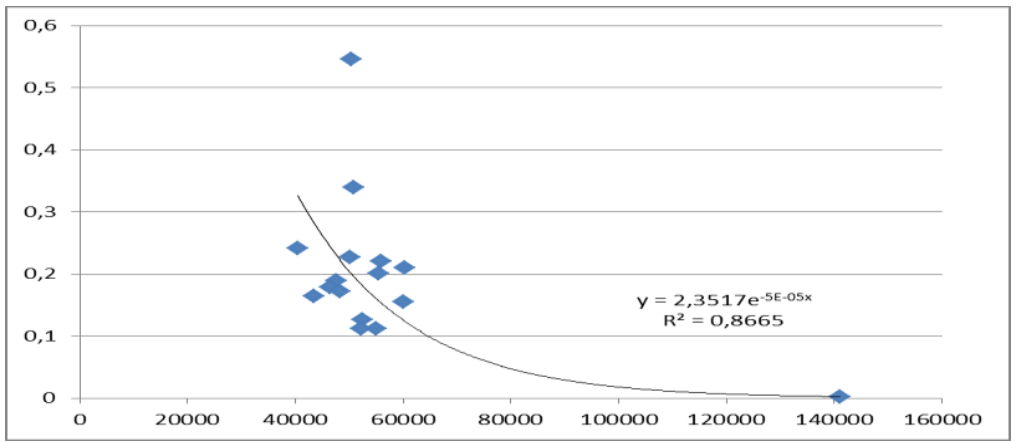

Fig 2. Effect of DIPC on the Herfindahl-Hirschman index (HHI)

The second indicator - migration growth (+), reduction (-) (Migration of population (M)), persons ${ }^{16}$. Visually it is not possible to detect the effect of this indicator on the Herfindahl-Hirschman indices (Fig. 3), the data are scattered heterogeneously. It is not possible to make unequivocally a statement about migration effect on market concentration, this is confirmed by the figures shown in Fig.4.

${ }^{16}$ Migration of population in 2018 http ://www.ukrstat.gov.ua/ 


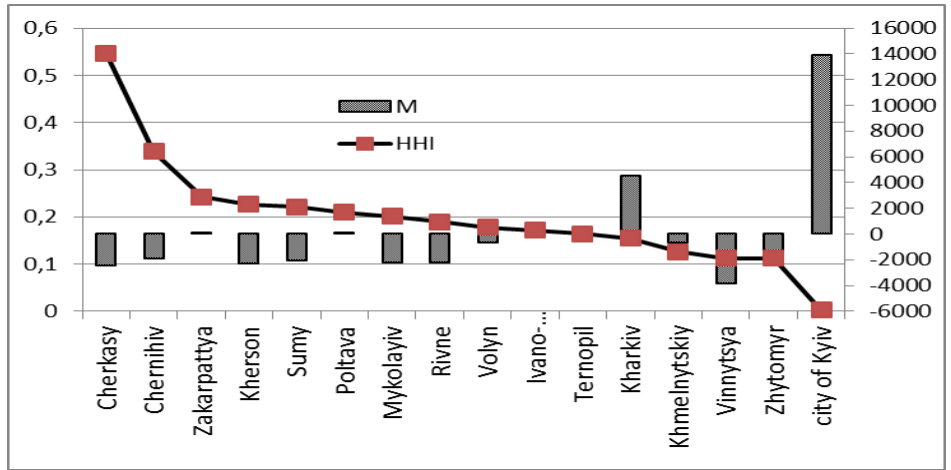

Fig. 3. Migration growth (+), reduction (-)

(Migration of population (M)) and Herfindahl-Hirschman indices (HHI) for various regions of Ukraine

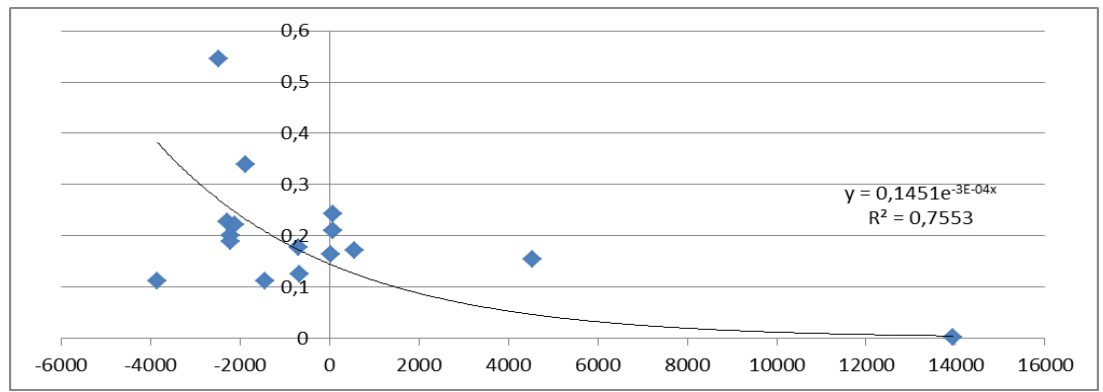

Fig. 4. Effect of migration (M) on the Herfindahl-Hirschman index (HHI)

At the national level, the most important general indicator of the country's development that characterizes the level of economic development is the gross national product (GNP), and at the regional level characterizing the level of economic development of a region, an area, it is the gross regional product (GRP). It is an indicator that measures the gross value added calculated by computing the difference between the output and the intermediate consumption for each type of economic activity, reduced by the payment for financial intermediary services. It includes all the primary income generated by production participants. Therefore, per capita gross 
regional product is chosen as the next indicator for the analysis (Per capita gross regional product (PCGRP) ${ }^{17}$, million UAH) (Fig. 5).

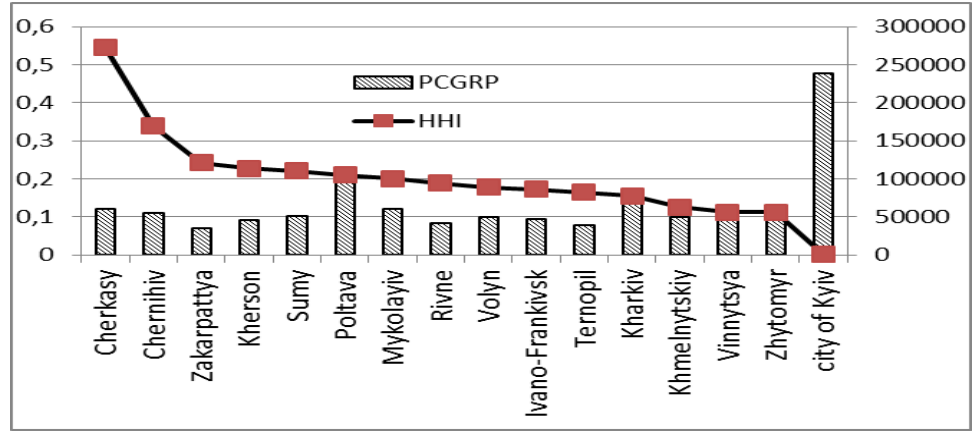

Fig. 5. Per capita gross regional product (PCGRP) and the HHI index for different regions of Ukraine

Effect of this indicator on the Herfindahl-Hirschman indices is shown in Fig. 6.

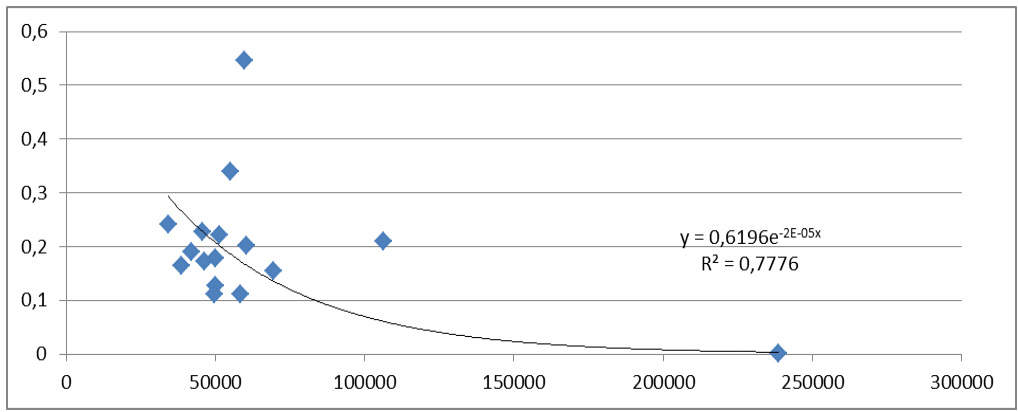

Fig. 6. Effect of PCGRP on the Herfindahl-Hirschman index (HHI)

The fourth indicator characterizing the business activity for the regions is the average monthly salary of one full-time employee (Average wages and salaries by region $(\mathrm{AW}))^{18}$, UAH. This indicator differs substantially by the regions of Ukraine, so in the Ternopil region the average monthly salary is 6969 UAH, while in Kyiv city it is almost two times larger - 13542 UAH.

${ }^{17}$ Gross regional product http://www.ukrstat.gov.ua/

${ }^{18}$ Average wages and salaries by region http://www.ukrstat.gov.ua/ 
The wages in the other regions have intermediate values, in between of these two (Fig. 7).

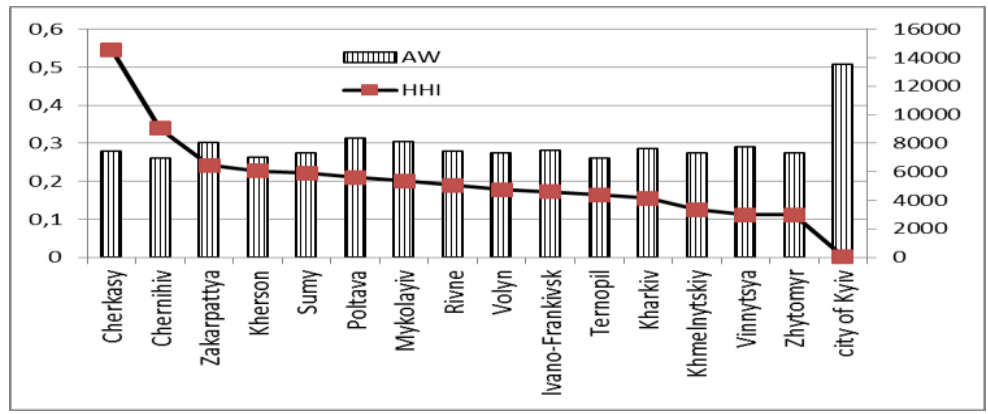

Fig. 7. The average wages and salaries by region (AW)) and the Herfindahl-Hirschman indices (HHI) for various regions of Ukraine

As one can see from Fig. 8, the degree of coverage by the model of the market concentration dependence on the level of the average monthly wages and salaries is 0.8412 , or $84.12 \%$, this is a fairly acceptable indicator.

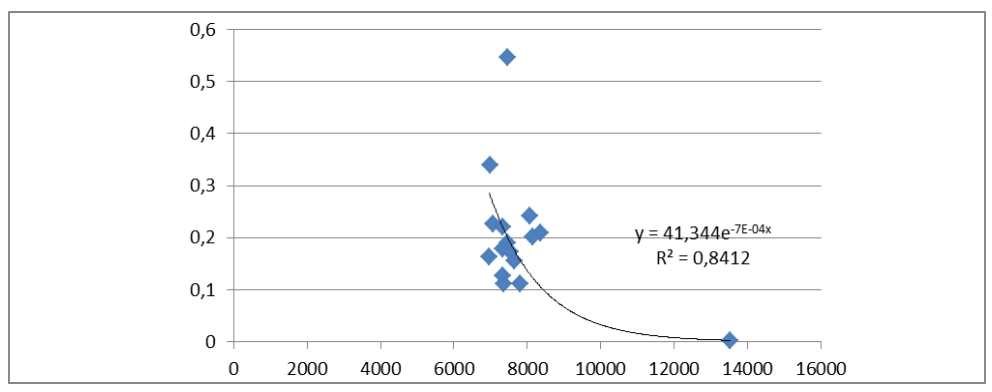

Fig. 8. Effect of average wages and salaries (AW) on the Herfindahl-Hirschman index (HHI)

The next factor characterizing the business activity in the regions of Ukraine is the indicator "capital investments by regions" (Capital investment by region) ${ }^{19}$, million UAH (Fig. 9), and it has sufficient coverage (Fig. 10).

${ }^{19}$ Capital investment by region http://www.ukrstat.gov.ua/ 


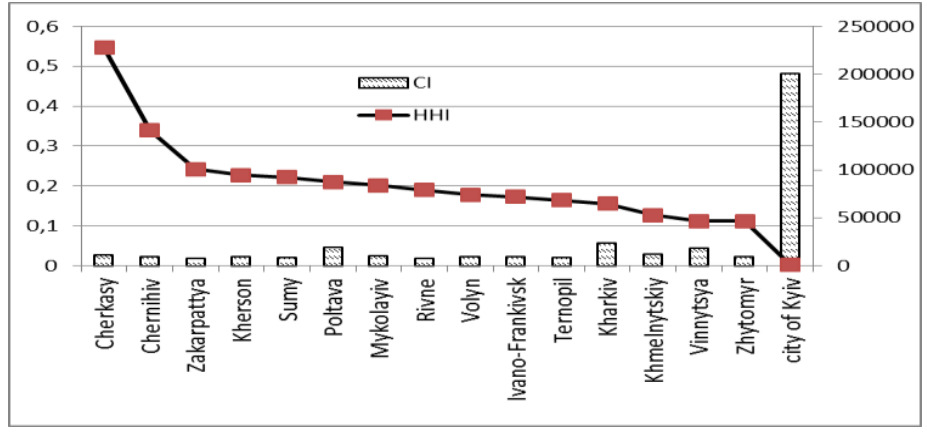

Fig. 9. Capital investments by regions

(Capital investment by region, CI) and the Herfindahl-Hirschman indices (HHI) for various regions of Ukraine

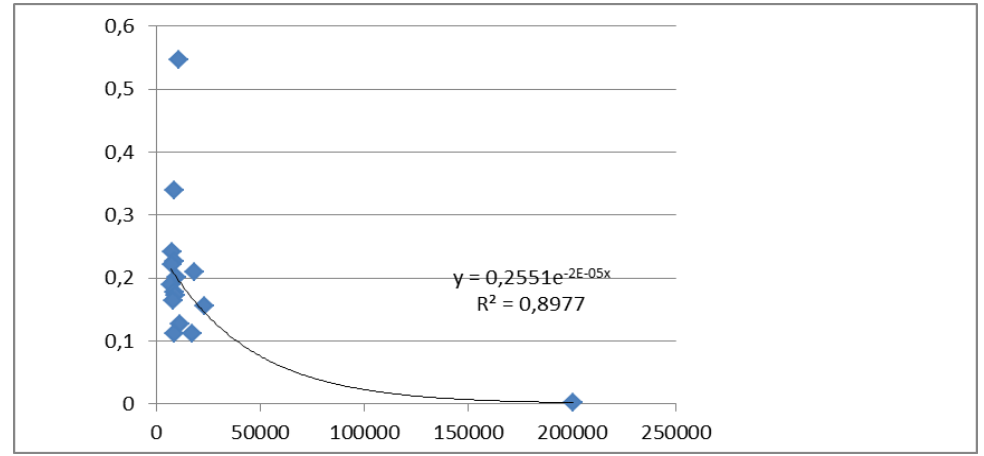

Fig. 10. The CI effect on the Herfindahl-Hirschman index (HHI)

Another indicator, not related to characteristics of business activity of an enterprise but possibly affecting the degree of concentration of new construction real estate markets, is the available total area of the housing stock in the region (indicator - housing stock (Housing stock by regions, $\mathrm{HS}^{20}$ ), thousand $\mathrm{m}^{2}$ of total area). We assume that with larger available housing stock market concentration is greater (Fig. 11).

${ }^{20}$ Housing stock by regions http://www.ukrstat.gov.ua/ 


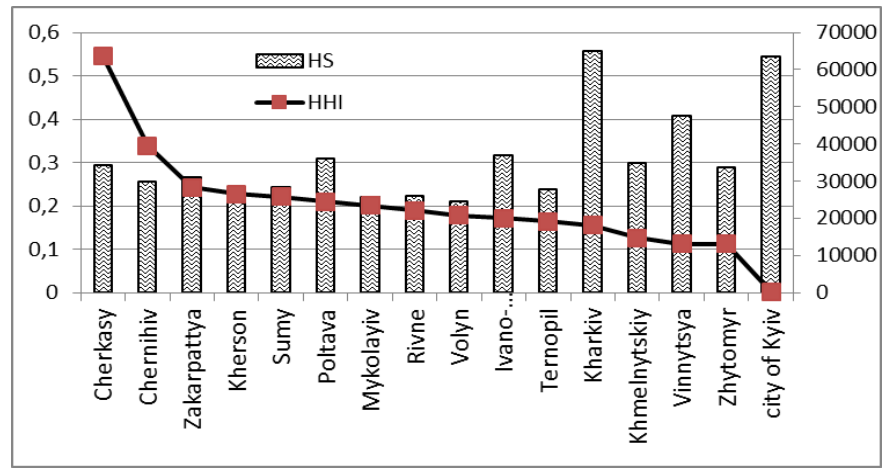

Fig. 11. Housing stock (Housing stock by regions (HS)) effect on the Herfindahl-Hirschman index (HHI)

But this hypothesis is not fortified by evidence. $\mathrm{R}^{2}$ is found to be only 0.3984 , this indicates a low degree of affecting factors coverage by the model (Fig. 12).

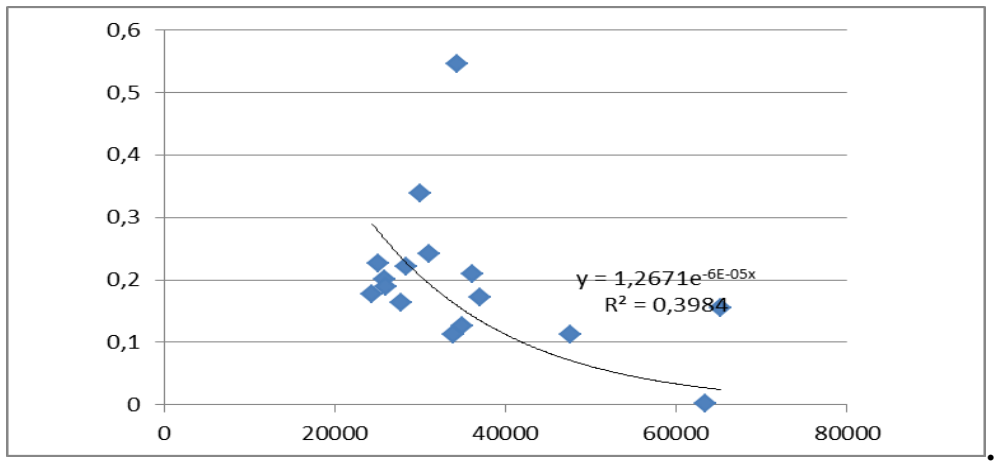

Fig. 12. Effect of HS on the HHI

The last factor for the business activity in the regions of Ukraine, the impact of which is studied in this paper, is the number of enterprises by regions (Number of enterprises by region, $\mathrm{NE})^{21}$. Visual overview of the NE and HHI graphs (Fig. 13) makes it possible to suggest that there is a dependence between these two values as well, this fact is supported by the Fig. 14.

\footnotetext{
${ }^{21}$ Number of enterprises by region http://www.ukrstat.gov.ua/
} 


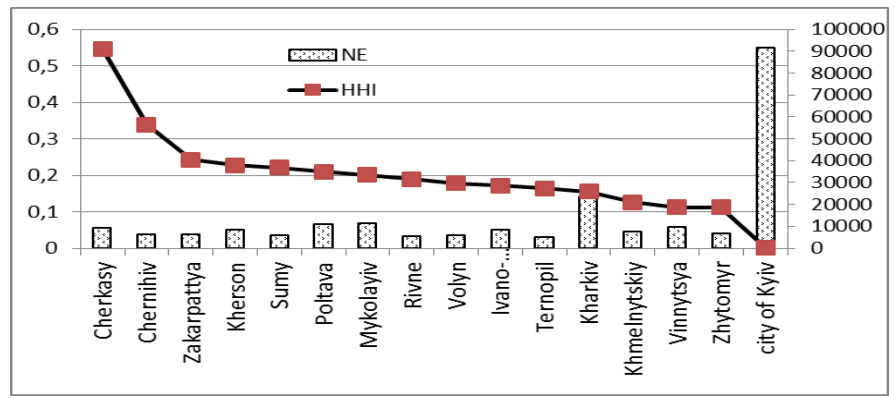

Fig. 13. The number of enterprises by regions

(Number of enterprises by region, NE) and the Herfindahl-Hirschman indices (HHI) for various regions of Ukraine)

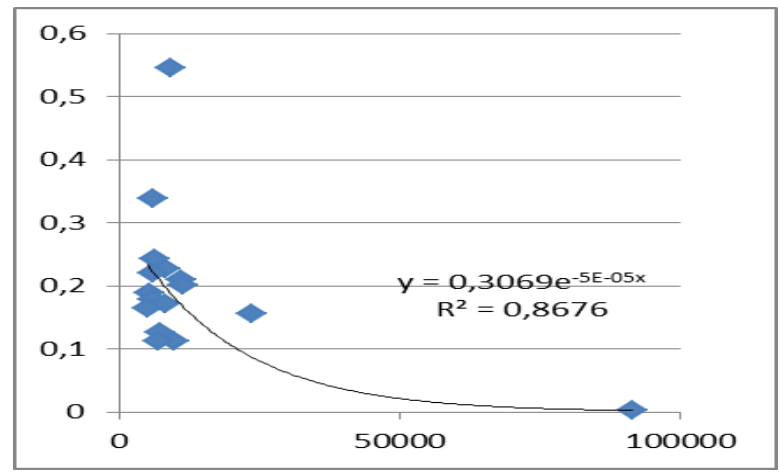

Fig. 14. Effect of the NE on the HHI

Selection of factors that have a sufficient degree of influence on the market concentration and a sufficient degree of prediction accuracy is based on the indicators $R^{2}$ and $\bar{\Delta} \mathrm{j}$ (Table 6 ). The value $\bar{\Delta} \mathrm{j}$ is the level of approximation for a particular model based on determination of its reliability by the value of the mean linear error:

$$
\begin{gathered}
\bar{\Delta}_{j}=\sum_{1}^{m} \Delta_{i} / m \\
\Delta_{i}=\left|\left(T_{i}^{\phi}-T_{i}^{p}\right) / T_{i}^{\phi}\right| \cdot 100
\end{gathered}
$$


where $\mathrm{T}^{\phi}$ - actual values of the indicator;

$\mathrm{T}^{\mathrm{p}}$ - calculated values of the indicator;

$\Delta \mathrm{i}-$ the linear error for the model by the $\mathrm{i}$-th observation $(\mathrm{i}=1,2 \ldots \mathrm{N})$.

The extent of coverage and the approximation level

Table 6

for the dependencies created

\begin{tabular}{|c|c|c|c|}
\hline No & Indicator & $\mathbf{R}^{\mathbf{2}}$ & $(\overline{\mathbf{\Delta}} \mathbf{j})$ \\
\hline 1 & Income per capita & 0.86 & 0.33 \\
\hline 2 & Migration & 0.76 & 0.54 \\
\hline 3 & GRP & 0.78 & 0.52 \\
\hline 4 & The average monthly salary of one full-time \\
employee & 0.84 & 0.46 \\
\hline 5 & Capital investments & 0.89 & 0.35 \\
\hline 6 & Total housing stock area & 0.4 & 1.18 \\
\hline 7 & Number of enterprises & 0.87 & 0.36 \\
\hline
\end{tabular}

\section{CONCLUSIONS}

According to the Table 6 it can be concluded that the market concentration of new construction real estate market is influenced by the following factors: capital investments, income per capita, number of enterprises in the region. A weak degree of coverage for the factor of the total housing stock area is found, thus this indicator has almost no effect on the new construction real estate market concentration.

However, the approximation levels of the models created are almost maximal (33\% for per capita income, $35 \%$ for capital investments, 36\% for the number of enterprises), this indicates that the accuracy of the models is not sufficiently high ${ }^{22}$. Therefore, to confirm the effect of these indicators on the market concentration additional studies should be carried out, possibly based on on the data for the regions where market concentration has not been evaluated, thus those can serve as the source of validation data.

\section{SUMMARY}

Currently, almost all the concentration indices used are fully or partially calculated and published in many countries by national statistical authorities. On the basis of those data constant monitoring of concentration processes is carried out.

In Ukraine, many of the above methods of calculation are practically not used at the state level, and calculation of specific indicators is complicated

${ }^{22}$ Economic and mathematical methods and models in construction [Text] (Ukrainian) : textbook for students of higher education institutions / V. O. Mihels [et al.] ; under the general editorship of Dr. of Sci.in economics, prof. V. O. Mikhels ; Kyiv National University of Construction and Architecture. - K. : Millenium, 2010. - 464 p. (in Ukrainian) 
by the lack of information on the construction market, this substantially distorts the real situation.

Continuous monitoring of the market situation, analysis of the level of competition, study of the trends in the development of individual markets at the level of specific regions, cities, areas, with identifying the type of competitive environment of the market shall make it possible to perform effective control of the state of competition in different regions of Ukraine, to prevent monopolization in a timely manner and to cease violations of antitrust laws.

It can be concluded that the degree of business activity in the regions of Ukraine plays a role in market concentration. Further studies should expand the range of indicators that characterize the change in business activity in specific regions, create a model that takes into account the role of those factors, etc.

Often enough at the periods of economic recovery the level of competition increases, due to high level of profitability and investment attractiveness of housing, new developers enter the market, and this reduces the level of concentration. At time of crisis the level of concentration is increasing since small companies are forced to leave the market, while large companies are forced to reduce the construction volumes. In the future studies it should be taken into account that concentration indices may vary depending on the phase of the economic cycle that characterizes the level of business activity over few, and possibly tens of years as well. Therefore, for each region the degree of new construction real estate market concentration can fluctuate depending on the phase of the economic cycle.

Monitoring of the indicators mentioned above will make it possible for the Antimonopoly Committee to develop a sound, effective antitrust policy aimed at enhancing the competitiveness in the construction industry.

\section{REFERENCES}

1. Bielienkova O.Yu., Tsifra T.Yu., Tsariuk T.M. Assessment of the processes of concentration and consolidation of banking capital in the CIS states and in the world. Ways of improving the efficiency of construction under conditions of formation of market relations .: Coll. scientific works. issue.23. - 2012. - P.9 -13

2. Gerasimenko V. Banking Capital Concentration and Methods of Assessing its Level. // Bulletin of the National Bank of Ukraine - 2007. No. 4 - P. 28-32.

3. Kyiv and Ukrainian Developers // New Buildings of Kyiv and Ukraine // [Electronic source] - Access mode: https://zabudovnyk.com.ua/ uk/developers/region/all

4. Information on housing property commissioning in Ukraine http://old.minregion.gov.ua/attachments/content-attachments/4858/.pdf 
5. Miniailo O.I., Burian A.M. The current state of competition in the new construction real estate market of Kyiv city // Business Inform. 2016. - No.4. - P. 126-130.

6. Onischenko Yu.I. Domestic banking system concentration level / [Electronic source] - Access mode: http://intkonf.org/onischenko-yui-rivenkontsentratsiyi-vitchiznyanoyi-bankivskoyi-sistemi/- Name from the screen.

7. Ukrainian developers predict increase in housing prices in 2016 // [Electronic source] - Access mode: http://ua.korrespondent. net/ business /realestate/3615553-ukrainski-zabudovnyky-prohnozuuit-podorozhchannia zhytla-v-2016-rotsi

8. Tsymbaliuk I.O. The mechanism for regulation of competitive relations in regional raw material markets: abstract. diss. Cand. of econom. Sci.: 08.00.05 / I.O. Tsymbaliuk; NAS of Ukraine. Inst-t of region. research. - L., 2008. -20 p.

9. Tsykhan T.V. Theoretical bases of control of economic concentration // www.jurenergo.kiev.ua/statti/osncontr.doc

10. Chyrkov Volodymyr. Market Concentration Indicators [Electronic source] - Access mode: http://www.kmu.gov.ua/amc/control/uk/ publish/ article? showHidden $=1 \&$ art_id $=49408 \&$ cat_id $=47049 \&$ ctime $=1202372165628$

11. Bain, J. (1951). Relation of Profit Rate to Concentration: American Manufacturing,1936- 1940. Quarterly Journal of Economics, 65(3), 293-324.

12. Bain, J. (1954). Economies of Scale, Concentration, and the Condition of Entry in Twenty Manufacturing Industries. American Economic Review, 44(1), 15-39.

13. Analytical materials on the consistency of respondents' estimates of the state of their business activities revealed by the results of the State statistical survey «State of business activity of enterprises», with intraannual statistical data http://www.ukrstat.gov.ua/operativ/operativ2015/ fin/rp/tend_act.pdf

14. Pavlov K.V., Pavlova O.M. Formation and regulation of competitive relations at regional housing markets of Ukraine: monograph. Lutsk. 2019. 542.

15. Pavlov K.V., Pavlova O.M. Regional market of real estate: conjuncture, factors of formation and influence. International Journal of New Economics, Public Administration and Law. Publisher: Cech Rzemiosł Różnych, Dr hab. 2019. 1(3).

16. Pavlov K.V. Assessment of competitiveness of the regional residential real estate markets of Ukraine: monograph. Lutsk. 2018. 482.

17. Danylina S.O. The system of indicators of concentration in economy 
http://dspace.oneu.edu.ua/jspui/bitstream/123456789/1640/1/Система\%20п оказників \%20концентрації\%20економіки.pdf

18. Kyryliuk A.O. Methods for estimating the level of economy concentration and monopolization http://www.economyandsociety.in.ua /journal/3_ukr/12.pdf

19. Bielienkova O. Yu. Evaluation of concentration of new construction real estate market of Kyiv city and Kyiv region / O. Yu. Bielienkova, T. Yu. Tsyfra, Yu. O. Zapiechna. // Actual problems of economy. - 2017. - No.6. - P. 196-203.

20. Grytsenko O. S. Evaluation of concentration of new construction real estate market of Donetsk region / O.S. Grytsenko, Yu.S. Zapiechna, I.V. Lysak // Control of complex system development. - 2017. - Issue. 32. P. 110-113.

21. Sorokina L.V. Investigation of influence of macroeconomic regulators on the dynamics of capital accumulation in the construction business of Ukraine / L.V. Sorokina // Current problems of economy. 2012. - No. 6. - P. 69-81. - Access mode: http://nbuv.gov.ua/UJRN/ ape_2012_6_10

22. An econometric toolkit for managing financial security of a construction company: [monogr.] / L.V. Sorokina, S.P. Stetsenko, A.F. Goiko, K.V. Izmailova, T.Yu. Tsyfra [et al.]; under sci. ed. of Doctor of Economics, prof. L.V. Sorokina. - K. : Kyiv National University of Construction and Architecture; Kryvyi Rih: Published SEP Cherniavskyi D.O., 2017. - P. 4-26.

23. Ryzhakova G. Implementation of principles of biospheric compatibility in the practice of ecological construction in Ukraine [Текст] / D. Chernyshev, I. Ivakhnenko, G.Ryzhakova, K.Predun // International Journal of Engineering \& Technology - UAE: Science Publishing Corporation, 2018- Vol 10. No 3.2: Special Issue 2 pp. 584-586.

24. Tetyana Marchuk, Dmytro Ryzhakov, Galyna Ryzhakova and Sergiy Stetsenko (2017). Identification of the basic elements of the innovationanalytical platform for energy efficiency in project financing. Investment Management and Financial Innovations Vol. 14(4), pp. 12-20.

\section{Information about the author: Bielienkova O. Yu.,}

$\mathrm{PhD}$ in Economics, Associate Professor, Associate Professor at the Department of Construction Economics, Kyiv National University of Construction and Architecture 31, Povitroflotsky Ave., Kyiv, 03037, Ukraine 


\section{STUDY OF THE TECHNOLOGY OF STRENGTHENING REINFORCED CONCRETE COLUMNS BY EXTERNAL REINFORCEMENT}

Molodid O. S.

\section{INTRODUCTION}

In the process of inspecting buildings and constructions, the technical state of the building constructions and of the building as a whole is diagnosed. Further, this work must result in the conclusions on the state of the building constructions and sound recommendations on the technical maintenance of the object and the measures to restore operating properties of the building construction and the object as a whole ${ }^{1}$.

Specialists from the State Enterprise "V.S. Balitsky Research Institute of Building Production" (SE "RIBP") continuously conduct technical inspections of buildings and constructions of various categories of complexity. In case non-typical damages are detected, or typical solutions for repair and restoration works ${ }^{2}$ cannot be used to solve a particular task, or there is a possibility to carry out repair and restoration works in a number of ways, the divisions of the SE "RIBP" apply a scientific and research approach to the solve the tasks at hand. In particular, if the Institute's scientific divisions need to solve a design and technology task, they first conduct theoretical research, which includes the development of scientific research program, program modelling of the work of the construction or the whole building in real-life conditions, plotting dependences etc. Further, as needed, laboratory, iron bird (bed) and field tests with the modelling of the work of the repaired or restored construction or whole building in real-life conditions. If there is a possibility to conduct repair and restoration works in several ways, the Institute's scientists research technical and economic parameters (value, duration and labor intensity of works, cost of the

${ }^{1}$ ДСТУ-Н Б В.1.2-18:2016 Настанова щодо обстеження будівель і споруд для визначення та оцінки їх технічного стану. - Київ: ДП «УкрНДНЦ», 2017. - 47 с.; Методические указания по обследованию фундаментов турбоагрегатов: РД 34.21.323-95. - М.: РАО «ЕЭС России», 1995. $-32 \mathrm{c}$.

${ }^{2}$ ДСТУ Б В.3.1-2:2016. Ремонт і підсилення несучих і огороджувальних будівельних конструкцій та основ будівель і споруд [Чинний від 2017-04-01]. - Київ: ДП «УкрНДНЦ», 2017. - 72 с.; 4. Беляков Ю. И. Романушко Е. Г. Запорожченко С. А. Средства механизации при реконструкции промышленных предприятий / Беляков Ю. И. Романушко Е. Г. Запорожченко С. А. - К.: Будівельник, 1987. - 144 с. 
materials, machines, mechanisms and other equipment necessary for a given technology etc.) of conducting the works using various methods and give recommendations as to the optimal design and technology solution for the operations.

\section{Minsk CHP-3 inspection}

The proposed research and scientific approach was used during a routine inspection of a complex building object, namely Minsk heat and power station (HPS) No. 3. The inspection was initiated by the staff of Minsk HPS No.3 branch, who noticed increased vibration on the pedestal of turbinegenerator PT $-60-130-13$ at station No.5. The vibration test showed that the maximum recorded vibration level reached $6.8 \mathrm{~mm} / \mathrm{sec}$, while the specification vibration level must not exceed $4.5 \mathrm{~mm} / \mathrm{sec}$. The specialists of the OJSC "Belenergoremnaladka" established that the higher-than-normal vibrational oscillations are created due to the deformability of the foundation structures, which is connected with its long-lasting operation (58 years).

As a construction, the foundation is a monolith frame system consisting of five interconnected frames and 8 ribs, and a common base slab. The foundation dimensions of in the plan are $24.5 \times 6 \mathrm{~m}$ (fig. 1). The height of the foundation is $10.8 \mathrm{~m}$. The top of the maintenance platform is $+7.0 \mathrm{~m}$, the top of the base slab $-3.8 \mathrm{~m}$.

Each separate frame of the foundation, with the height of $10.8 \mathrm{~m}$, is formed of two vertical elements (columns or piers) divided in two, in some places in three, tiers by floor slaps $200 \mathrm{~mm}$ in thickness, and united by a beam in the upper part into a common construction. The cross-section of the vertical elements varies from $1.0 \times 0.6$ to $1.1 \times 3.9 \mathrm{~m}$.

First, the following program of works was drawn up: study and analysis of process design and post-completion documentation, visual and instrumental inspection of the superstructure block of the foundation; development of a project design to strengthen the foundation constructions; development of a work order project to strengthen the foundation; vibrodiagnostics of the foundation state after strengthening.

In the course of the visual and instrumental inspection of the foundation, the following was detected:

1) oiling of the surface on the concrete areas of frames 3,4 and 5 with up to $50 \mathrm{~mm}$ depth of over $17 \%$ of the foundation surface;

2) a through crack up to $1 \mathrm{~mm}$ in width in the upper part of the pier of frame 2 adjacent to the plate; cracks in the longitudinal beam between frames 2 and 3, some of the cracks are covered with oil;

3 ) wreckage of the protective coat of the concrete and reinforcement corrosion are found in over $15 \%$ of the surface; 
4) measuring of the actual strength of concrete by nondestructive inspection techniques revealed that the strength of concrete is not even for all elements of the foundation and fluctuates between 119.7 and $335.7 \mathrm{~kg} / \mathrm{cm}^{2}$ (by scratching test) and between 107.5 and $292 \mathrm{~kg} / \mathrm{cm}^{2}$ (by ultrasound test), while the design value is $150 \mathrm{~kg} / \mathrm{cm}^{2}$;

5) constructions with incorrectly performed lift joints, areas of the foundation with poorly vibrated concrete, bare reinforcement without a protective concrete layer;

6) soaking of reinforced concrete constructions on $28 \%$ of the surface;

7) the works to asses the actual geometrical dimensions of the superstructure block of the foundation it was detected that deviations of actual dimensions of some elements of reinforced concrete constructions from the design position reach up to $76 \mathrm{~mm}$. It was also determined that skewness of separate vertical elements was $45 \mathrm{~mm}$.
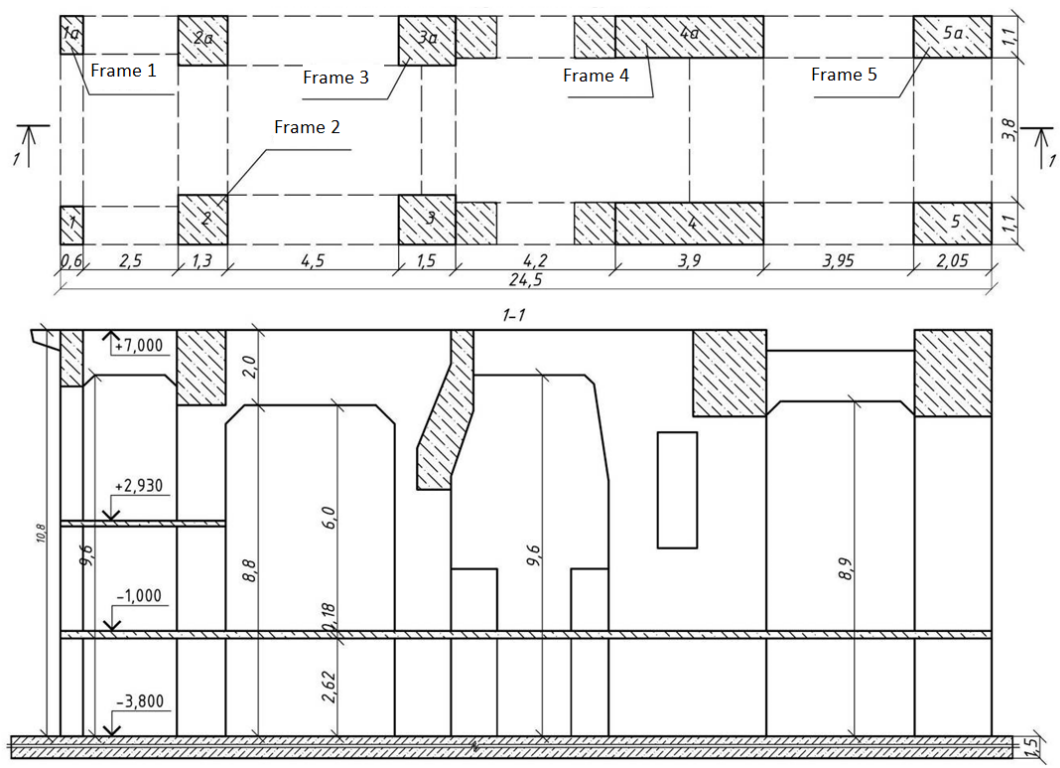

Fig. 1. Plan and cross-section of the superstructure block of the turbine-generator set foundation

Based on the data collected during the inspection, specialists of the SE "RIBP" developed a structural design and a work order project to strengthen the reinforced concrete foundation of Minsk HPS No.3 with metal casing 
and extra underpinned portal frames using sprayed-on plaster and composite materials.

Considering the significant height of the supporting structures (up to $6.2 \mathrm{~m}$ ), their vertical unevenness and a large number of defects therein, a new technology for conducting works to strengthen the supporting structures with casing was developed, as under such conditions, classical design and technology solutions could not be used ${ }^{3}$. The developed technology differed from classical ones in that it did not provide for tight adherence of metal casing to the edges of the strengthened supporting structures, and the clearance between the foundation planes and the outer side of the casing angles exceeded $20 \mathrm{~mm}$. The space between the post and the casing was filled with sprayed-on plaster, following which the whole surface was plastered and smoothed level with the upper edges of the casing angles.

\section{Experimental tests of design and technology solution for strengthening columns}

Besides, before the developed design and technology solution was introduced into the design documentation, a number of laboratory and iron bird experimental tests were conducted to confirm its feasibility and efficiency.

First, the operational concept provided for strengthening the supporting structures with external reinforcement, i.e. by gluing extra-strong carbon fibers ${ }^{4}$. So, to establish the dependence of the impact of technological factors on the compression breaking strength of the strengthened fragments of columns, a number of experimental tests was conducted to check the efficiency of this technology.

The main structural and technological and, per se, technological factors which can influence the efficiency of strengthening vertical load-bearing reinforced concrete structures are as follows:

- presence / absence of acute angles;

- foundation preparation (pre-coating of the surface);

- the method of gluing the reinforcement (fiber) to the construction.

${ }^{3}$ Савйовский В. В., Болотских О. Н. Ремонт и рекострукция гражданских зданий/ Савйовский В.В., Болотских О.Н. -Х.: Ватерпас, 1999. - 288 с. ;6. Савйовський В. В. Реконструкція будівель і споруд / В. В. Савйовський. - К.: Видавництво Ліра-К, 2018. $320 \mathrm{c}$.

${ }^{4}$ Овчинников И. И., Овчинников И.Г., Чесноков Г.В., Михалдыкин Е.С. Анализ экспериментальных исследований по усилению железобетонных конструкций полимерными композитными материалами. Часть 1. Отечественные эксперименты при статическом нагружении // Интернет-журнал «НАУКОВЕДЕНИЕ» Том 8, №3 (2016); Савйовський В. В. Підсилення залізобетонних балочних конструкцій зовнішнім армуванням/ В. В. Савйовський, О. С. Молодід, Н. О. Малець // Управління розвитком складних систем. - 2017. - № 29. - С. 198 - 204. 
Reinforced concrete lintels of 2 PB 10-1 type were used with the following characteristics: dimensions (length $\mathrm{x}$ width $\mathrm{x}$ height) $-1030 \mathrm{x} 120$ $\mathrm{x} 140$, concrete grade - C12/15. These beams were cut lengthwise into fragments $230 \mathrm{~mm}$ each.

The samples were reinforced by gluing unidirectional carbon fibers to all their lateral surfaces by wrapping.

Six series of experimental tests were planned:

- series 1 - no actions were performed with the control samples (no reinforcement was added) (fig. 2);

- series 2 - the samples' angles were rounded, their surface was precoated, a coat of glue was applied, in which carbon fiber was sunk, and an extra coat of glue was applied on top of the fiber;

- series 3 - the samples' angles were not rounded, their surface was pre-coated, a coat of glue was applied, in which carbon fiber was sunk, and an extra coat of glue was applied on top of the fiber;

- series 4 - the samples' angles were rounded, a coat of glue was applied, in which carbon fiber was sunk, and an extra coat of glue was applied on top of the fiber;

- series 5 - the samples' angles were rounded, a coat of glue was applied, in which the carbon fiber was sunk,

- series 6 - the samples' angles were rounded, carbon fiber impregnated with glue was glued to the surface.

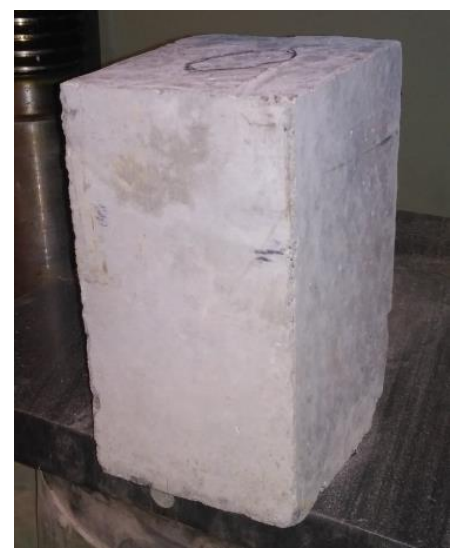

Fig. 2. Overall view of a nonreinforced sample

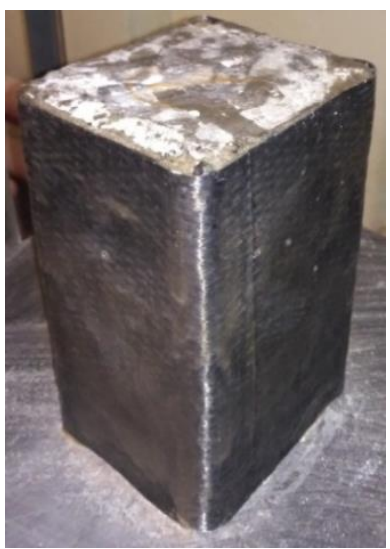

Fig. 3. Overall view of a reinforced sample 
Before carbon fibers was glued to the samples, their lateral surfaces were cleaned and pre-coated with Consolid-1 primer manufactured by COMPOSIT LLC, Kyiv (if provided for) ${ }^{5}$.

For the samples whose surface was pre-coated, further actions were taken at least in 24 hours. In other cases the fiber was glued immediately after the angles were rounded, the lateral surfaces were cleaned and dust removed therefrom.

EDMOK glue manufactured by COMPOSIT LLC, Kyiv was applied to the prepared surface, and strips of carbon fiber were sunk into the glue by a putty knife. In 5-10 minutes, another layer of EDMOK glue was applied on the surface so that it covered the whole surface.

In test series 6 carbon fiber was completely impregnated with glue in a special container, and then glued to the surface. It should be said that this way of gluing fibers to the surface increases the amount of glue almost 2 times in comparison with the method described above. Besides, when applying the fiber air pockets were formed under the fiber impregnated with glue, which were difficult to remove. Additional inconveniences included the need to drain the excess of the glue from the fiber and the fiber slipping off the construction.

The tests were conducted under the temperature $+(15-22){ }^{\circ} \mathrm{C}$ on $\mathrm{P}-125$ testing machine according to axial compression scheme 96 hours after external reinforcement had been glued. The loading was applied to the samples in $2000 \mathrm{~kg}$ steps. The tests were conducted until the complete demolition of the samples.

The experimental test results and fracture patterns of samples strengthened by various methods are displayed in table 1 .

The experimental tests analysis demonstrated that the highest bearing strength was reached on the samples of columns with rounded angles, where glue was applied on the basis of the sample and on carbon fiber (40.6 ton) (test series 4). The compression strength of such samples is $82.2 \%$ higher than that of the control samples (test series 1). Almost similar increase in strength, i.e., $81.7 \%$ as compared with the control samples, was achieved with the samples (test series 2), where besides the solutions used to strengthen the previous samples, the base was pre-coated. Analyzing the test results, we can state that the technological factor - pre-coating of sample surfaces before their reinforcement - does not increase strength, thus, it is impractical to perform this technological operation when strengthening columns.

\footnotetext{
5 Технологическая карта: на выполнение работ по восстановлению кирпичных, железобетонных конструкций и их защите. ООО «Композит». - К.: - 2009. - 7 с.
} 
Table 1

Experimental test results to determine the samples' breaking force

\begin{tabular}{|c|c|c|c|}
\hline $\begin{array}{c}\begin{array}{c}\text { No. of } \\
\text { test } \\
\text { series }\end{array} \\
\end{array}$ & $\begin{array}{c}\text { Average } \\
\text { breaking } \\
\text { force, tons }\end{array}$ & $\begin{array}{c}\text { Average } \\
\text { breaking } \\
\text { force, \% } \\
\end{array}$ & Sample fracture pattern (photo) \\
\hline 1 & 22.3 & 100 & \\
\hline 2 & 40.5 & 181.7 & \\
\hline 3 & 34.0 & 152.5 & \\
\hline 4 & 40.6 & 182.2 & \\
\hline 5 & 38.6 & 173.4 & \\
\hline 6 & 38.8 & 174.3 & \\
\hline
\end{tabular}

The compression strength of the strengthened samples in which the angles were not rounded (test series 3 ) was found to be the lowest, namely 
34.0 tons, which is $52.2 \%$ higher comparing with the control samples and $29.7 \%$ lower than the strength of test series 4 samples. It should be said that on such samples the carbon fiber tore at the angles, which can indicate that the fibers were cut by sharp sample angles, or, alternatively, that supernormal tension was created at the angles leading to fiber tearing in these places.

The results of experimental tests of sample series 6 demonstrated that their compression strength is $74.3 \%$ higher than that of the control samples ad $7.9 \%$ lower than the strength of test series 4 samples. It is worth mentioning that in real-life conditions of construction this technology is difficult to implement, as it has a number of disadvantages described above.

The compression strength of test series 5 samples is 38.6 tons, which is $73.4 \%$ higher than that of the control samples and $8.8 \%$ lower than the strength of test series 4 samples. This technology may be used in further research and in conducting similar works in construction, as the absence of the upper layer of glue cuts the manufacturing and labor costs, as well as the performance time.

At the next stage of experimental tests, the design and technology solutions were tried on sample columns. Here, it was planned to study certain solutions implemented at the previous stage and the solutions proposed to be included in the design documentation. Also, the efficiency of strengthening columns with a classical method, namely a metal casing with pre-stressed plates, was tested.

Reinforced concrete lintels of 2 PB 10-1 type were used with the following characteristics: dimensions (length $\mathrm{x}$ width $\mathrm{x}$ height) $-1030 \mathrm{x} 120$ $\mathrm{x} 140$, concrete grade $-\mathrm{C} 12 / 15$. Fragments were cut off of these ribs, leaving a rib $800 \mathrm{~mm}$ in length, with which further tests were conducted.

Seven series of experimental tests were planned (fig. 4, 5):

- series 1 - no actions were performed with the control samples (no reinforcement was added) (

- series 2 - the samples' angles were rounded, their surface was precoated, a coat of glue was applied, in which carbon fiber strips was sunk, and an extra coat of glue was applied on top of the fiber (the fiber was glued with the materials manufactured by COMPOSIT LLC);

- series 3 - the samples' angles were rounded, their surface was precoated, a coat of glue was applied, in which carbon fiber strips was sunk, and an extra coat of glue was applied on top of the fiber (the fiber was glued with the materials of MAPEI ${ }^{\mathrm{TM}}$ );

- series 4- metal casing with pre-stressed plates;

- series 5-metal casing at the distance of $10 \mathrm{~mm}$ along the perimeter from the column with further application of sprayed-on plaster, while the cavity pockets between the column angles and casing angles were filled; 
- series 6 - the samples' angles were rounded, their surface was precoated, a coat of glue was applied, in which polyethylene-terephthalate fiber was sunk, covering the whole surface, and an extra coat of glue was applied on top of the fiber (the fiber was glued with the materials manufactured by COMPOSIT LLC);

- series 7 - the samples' angles were rounded, their surface was precoated, a coat of glue was applied, in which the carbon fiber was sunk, covering the whole surface, and an extra coat of glue was applied on top of the fiber (the fiber was glued with the materials manufactured by COMPOSIT LLC).

The prepared samples were tested with the method used at the previous stage. The test results are presented in Table 2.

- The analysis of the experimental test results demonstrated that the highest bearing strength was reached on the samples of columns with full strengthening with carbon fibers (54.4 tons) (test series 7 ). The compression strength of such samples is $97.9 \%$ higher than that of the control samples (test series 1). The strength increase by $52.5 \%$ and $54.5 \%$ as compared with the control samples was reached in the samples with metal casing and plaster and samples strengthened with strips of carbon fiber glued with the materials manufactured by COMPOSIT LLC (test series 5 and 2). Strengthening columns using the classical technology (test series 4) increased its compression strength by $37.6 \%$ as compared with the control samples.
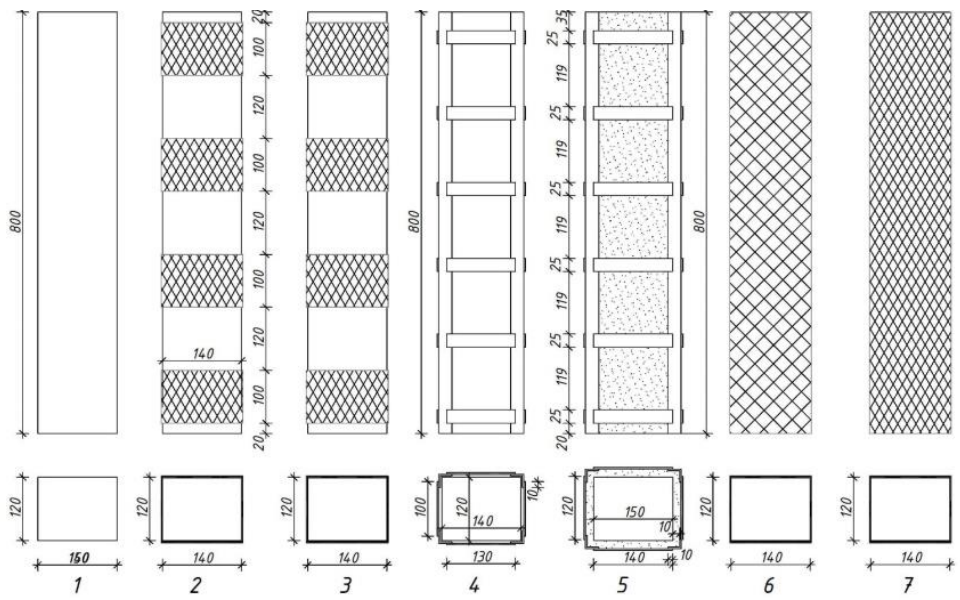

Fig. 4. Patterns of sample strengthening in test series 
Table 2

Experimental test results in determining breaking forces of columns

\begin{tabular}{|c|c|c|}
\hline No. of test series & Average breaking force, tons & Average breaking force, \% \\
\hline 1 & 27.5 & 100 \\
\hline 2 & 42.5 & 154.5 \\
\hline 3 & 32.7 & 118.9 \\
\hline 4 & 37.6 & 136.7 \\
\hline 5 & 46.6 & 152.5 \\
\hline 6 & 36.6 & 133.1 \\
\hline 7 & 54.4 & 197.9 \\
\hline
\end{tabular}

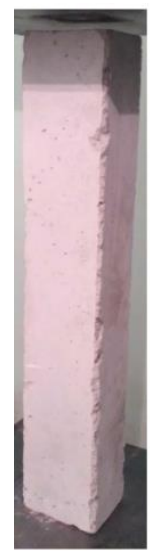

a

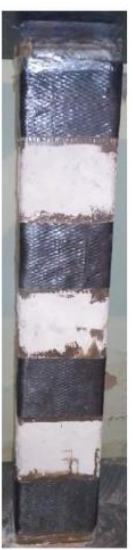

b

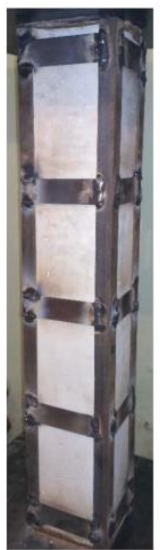

$\mathrm{c}$

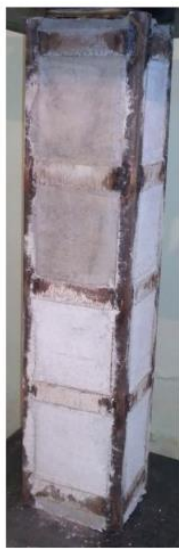

d

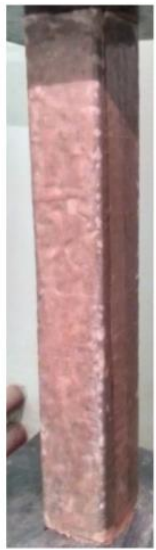

e

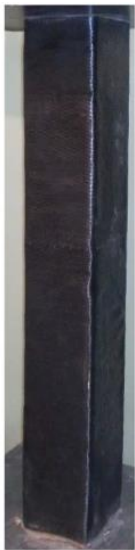

f

Fig. 5. General view of the tested columns:

$\mathrm{a}$ - not strengthened (series 1 ); $\mathrm{b}$ - strengthened with carbon fiber strips (series 2, 3); c-strengthened with metal casing with pre-stressed plates (series 4 ); $d$ - metal casing at a distance from the column with the cavity pocket filled with plaster (series 5); e - solid strengthening with polyethylene-terephthalate fabric (series 6); $\mathrm{f}$ - solid strengthening with carbon fabric (series 7)

Fracture of the tested column samples is displayed at fig. 6 


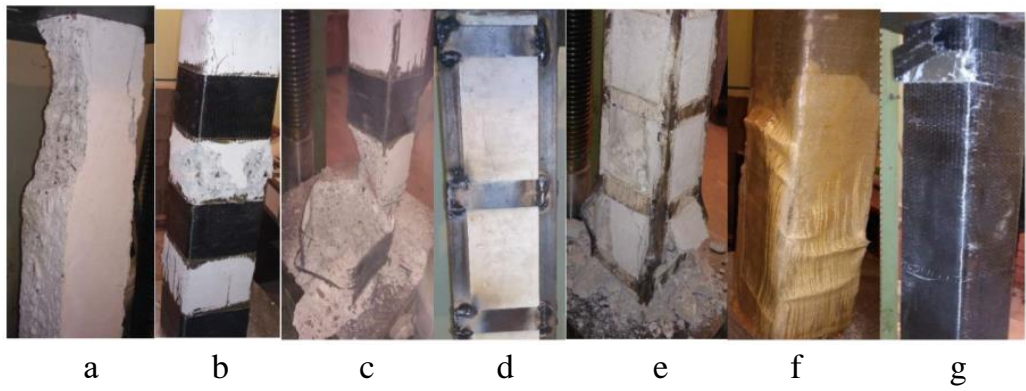

Fig. 6. General view of the columns after the tests:

$\mathrm{a}$ - not strengthened (series 1 ); $\mathrm{b}$ - strengthened with carbon fiber strips (series 2); c-strengthened with metal casing with pre-stressed plates (series 3);

$\mathrm{d}$ - strengthened with metal casing with pre-stressed plates (series 4); $\mathrm{e}$ - metal casing at a distance from the column with the cavity pocket filled with plaster (series 5); $\mathrm{f}$ - solid strengthening with polyethylene-terephthalate fabric (series 6); $\mathrm{g}$ - solid strengthening with carbon fabric (series 7)

The analysis of the data received in the course of the experimental tests leads to believe that the proposed design and technology solution for strengthening the foundation support structures where the metal casing is fixed at a certain distance from the support structure, and the space between the column and the casing is filled with spayed-on plaster, is an effective strengthening method, as it allows to increase the bearing strength of the support structures roughly by $50 \%$. The experimental test data show that the most effective solution is to strengthen the support structures with carbon fiber; however, the in-depth analysis of the permissible conditions for operational capacity of this method revealed that constructions strengthened with the use of epoxy-based glues cannot be operated at high temperatures. It is evident that temperature and humidity at HPS are always high, which is why the method of strengthening the support structures with carbon fiber glued with epoxy-based glue was not considered in the design documentation, although its efficiency significantly exceeds the efficiency of the rest of the methods.

The use of a specially developed design and technology solution for strengthening the support structures with the help of metal casing positioned at a certain distance from the column, where the space between the column and the casing is filled with spayed-on plaster mixture eliminated the need to preliminary straighten the lateral edges of the support structures and to repair concrete defects, which significantly decreased the work labor input and their duration. 


\section{Implementation of results of the experimental tests}

Before the strengthening of the turbine-generator foundation had been commenced, the impact of how constructions and technological equipment limited the spread of work and the conditions of performing the works was analyzed. Based on this analysis, the equipment and utility networks hindering the works on strengthening constructions were dismantled where possible; points of connecting tools and equipment with the existing energy supply networks were installed; a set of auxiliary measures was taken to ensure operational safety under the conditions of on-going operations and to protect the technological equipment, utility networks, materials and finished products from possible damage or contamination in the course of construction works.

Before the works were commenced, the working area was fenced with demountable hurdle with warning signs affixed to it.

The preparation included the following technological operations: installation of scaffolding, fixing of lifting tackles and fitting welder operators' platforms.

The strengthening of the vertical elements of foundation frames (support structures and columns) with metal casings on the first and second tear (at the height of $2.62 \mathrm{~m}$ and 5.2 and $6.2 \mathrm{~m}$ respectively) was carried out for the whole height in one operation. The angles were fitted and welded in pairs. First, the angles were located in the design position at the columns' angles so that the space between the plane of the column and the interior of the angles was not less than $20 \mathrm{~mm}$. The angles were fixed in this position by welding to each pair of angles of metal strips in four points throughout the whole height of the structure.

The comprehensive process of strengthening the support structures of the frames consisted of a number of simple processes: surface preparation, assembly of metal casing (fig. 7, a); application of Consolid-1 and Consolid-2 composite materials manufactured by COMPOSIT LLC; application of sprayed-on plaster (fig. 7, b).

The simple processes were completed in the following order: cleaning the foundation surface from dust, dirt, oil and bitumen stains; pulling of cracks; pre-coating of separate areas; application of repair polymer-cement mixtures in separate places; installation of the metal casing composed of angles, and of a part of connecting plates made of sheet metal and bearing blocks; pre-coating of the surface with two layers of Consolid-1 composite material; applying of one layer of Consolid-2 composite material; concrete spraying of the surface; welding of the remaining connecting plates, anti- 
corrosive protection of the welding connections; applying one layer of Consolid-1 composite material on the surface (fig. $7, \mathrm{c})^{6}$.

In this technology, Consolid-1 composite material was used to enhance the strength of the existing concrete of the foundation, and Consolid-2 - to enhance the strength of grip between the existing concrete constructions of the foundation with the subsequently applied layers. Polymer composite materials were applied by spraying on hard-to-reach areas and on the concrete under the casing, and by spreading on the open areas. The second layer of Consolid-1 was applied 18-24 hours after the first one; after that, a layer of Consolid-2 was applied by small portions onto the freshly applied layer of Consolid-1. During 2-4 hours, plaster mixture was applied onto the layer of Consolid-2. The time specifications for working with polymer compounds were adopted in accordance with the material manufacturer's recommendations.

Concrete spraying was completed from bottom up in tiers of 1.2-1.5 m for the whole width of the support constructions. First, the space between the planes of the existing construction and the inner side of the angles was filled with plaster, next - the space between the posts with angles. The plaster was applied in layers: the thickness of the first layer was $1 \mathrm{~cm}$, of the next layer 1.5-2.0 $\mathrm{cm}$ (up to the upper plane of the casing angles), with a 4-hour technological break between the time of applying the layers. The surface of the last plaster layers was smoothed and evened. In 18-20 days, the surface of the plaster and metal elements of the casing was covered with a layer of Consolid-1.

Separate horizontal constructions of the foundations, i.e. beams between frames 2 and 3, were strengthened by placing additional portal frames. An additional portal frame consists of 6 support structures with H-shaped crosssection placed on the first and second tiers. To evenly distribute the force, horizontal H-shaped beams were placed on the support structures of the first tier, whereupon the posts, together with the beams, were tightened to the bottom of the floor slab. This was achieved by screwing in bolts provided for in the bottom part of the support structures. The space between the foundation plate and the support structure plate was covered with concrete.

\footnotetext{
${ }^{6}$ Организация строительного производства: ТКП 45-1.03-161-2009. [Действующий с 2014-07-01]. - Минск: Минстройархитектуры Республики Беларусь 2014. - 48 с.; Технологическая документация при производстве строительно-монтажных работ. Состав, порядок разработки, согласования и утверждения технологических карт: ТКП 45-1.01159-2009 (02250). [Действующий с 2009-09-30]. - Минск: Минстройархитектуры Республики Беларусь 2009. - 16 с.
} 


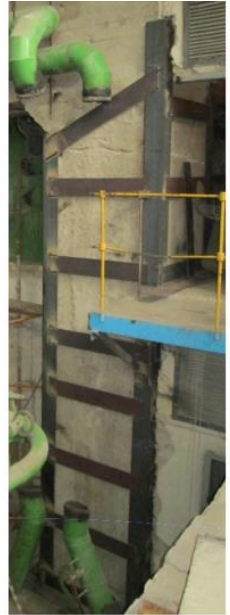

a

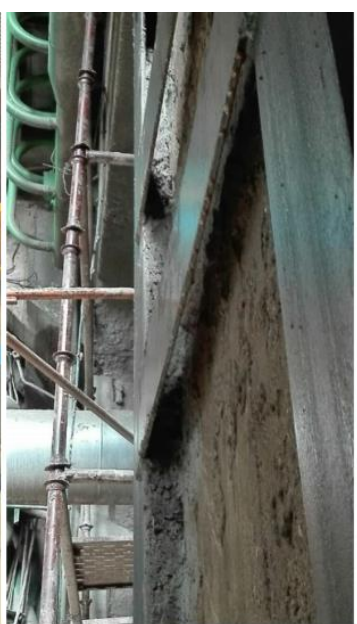

b

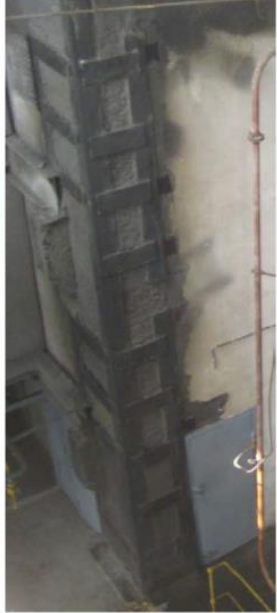

c

Fig. 7. Photos demonstrating the process of column strengthening: $\mathrm{a}$ - fitting of metal casings; $\mathrm{b}$ - filling cavity pockets between the column angles and casing angles with sprayed-on plaster; $\mathrm{c}$ - strengthened column

A month after the turbine-generator launch, both the level of vibration speed of the turbine and of the foundation was checked. The assessment demonstrated that the maximum recorded level of vibration speed reached $2.7 \mathrm{~mm} / \mathrm{s}$, with the standard indicator of $4.5 \mathrm{~m} / \mathrm{s}$.

\section{CONCLUSION}

A comprehensive approach to solving the problem of the strength and stability of the foundation constructions under the turbine-generator, which included visual and instrumental inspection of the foundation construction, development of a project design to strengthen the foundation constructions, development of a work order project to strengthen the foundation, made it possible to restore the designed bearing strength of the foundation.

The design and technology solutions for strengthening columns before they are used in the construction underwent experimental testing in laboratory and iron bird samples. Based on the test results, it was established that the proposed method allows to increase the bearing strength of the support structures roughly by $50 \%$. 
The repair and recovery works allowed to reach the level of vibration speed of $2.7 \mathrm{~mm} / \mathrm{s}$, which is 2.5 times lower of the vibration speed observed before the works were conducted $(6.8 \mathrm{~mm} / \mathrm{s})$.

\section{SUMMARY}

The article deals with a comprehensive approach to technical inspections of buildings and constructions and designing repair and restoration works, which is composed of the development of scientific research program, program modelling of the work of the construction or the whole building in real-life conditions, plotting dependences etc. Further, as needed, laboratory, iron bird (bed) and field tests with the modelling of the work of the repaired or restored construction or whole building in real-life conditions. Only then design documentation for repair and restoration works is developed.

This approach was tested on the foundation of the turbine-generator set of Minks HPS No. 3. In accordance with the developed program, the following works were conducted: study and analysis of process design and post-completion documentation, visual and instrumental inspection of the superstructure block of the foundation; development of a project design to strengthen the foundation constructions; development of a work order project to strengthen the foundation; vibrodiagnostics of the foundation state after strengthening. Based on the data collected during the inspection, structural design and a work order project were developed to strengthen the reinforced concrete foundation with metal casing and extra underpinned portal frames using sprayed-on plaster and composite materials. The peculiar feature of the developed technology was that the casing angles were adjusted at the distance not less than $20 \mathrm{~mm}$ from the angles of the strengthened posts, and the space between the metal casing and the reinforced concrete construction was filled with sand-cement mixture by spraying.

Besides, before the developed design and technology solution was introduced into the design documentation, a number of laboratory and iron bird experimental tests were conducted to confirm its feasibility and efficiency.

The analysis of the data received in the course of the experimental tests leads to believe that the proposed design and technology solution for strengthening the foundation support structures is an effective strengthening method, as it allows to increase the bearing strength of the support structures roughly by $50 \%$. 
The repair and recovery works allowed to reach the level of vibration speed of $2.7 \mathrm{~mm} / \mathrm{s}$, which is 2.5 times lower of the vibration speed observed before the works were conducted $(6.8 \mathrm{~mm} / \mathrm{s})$.

\section{REFERENCES}

1. ДСТУ-Н Б В.1.2-18:2016 Настанова щодо обстеження будівель і споруд для визначення та оцінки їх технічного стану. - Київ: ДП «УкрНДНЦ», 2017. - 47 с.

2. Методические указания по обследованию фундаментов турбоагрегатов: РД 34.21.323-95. - М.: РАО «ЕЭС России», 1995. - 32 с.

3. ДСТУ Б В.3.1-2:2016. Ремонт і підсилення несучих i огороджувальних будівельних конструкцій та основ будівель і споруд [Чинний від 2017-04-01]. - Київ: ДП «УкрНДНЦ», 2017. - 72 с.

4. Беляков Ю. И. Романушко Е. Г. Запорожченко С. А. Средства механизации при реконструкции промышленных предприятий/ Беляков Ю. И. Романушко Е. Г. Запорожченко С. А. - К.: Будівельник, 1987. $144 \mathrm{c}$.

5. Савйовский В. В., Болотских О. Н. Ремонт и реконструкция гражданских зданий/ Савйовский В.В., Болотских О.Н. -Х.: Ватерпас, 1999. - $288 \mathrm{c}$.

6. Савйовський В. В. Реконструкція будівель i споруд / В. В. Савйовський. - К.: Видавництво Ліра-К, 2018. - 320 с.

7. Овчинников И. И., Овчинников И.Г., Чесноков Г.В., Михалдыкин Е.С. Анализ экспериментальных исследований по усилению железобетонных конструкций полимерными композитными материалами. Часть 1. Отечественные эксперименты при статическом нагружении // Интернет-журнал «НАУКОВЕДЕНИЕ» Том 8, № 3 (2016).

8. Савйовський В. В. Підсилення залізобетонних балочних конструкцій зовнішнім армуванням/ В. В. Савйовський, О. С. Молодід, Н. О. Малець // Управління розвитком складних систем. - 2017. № 29. - C. 198 - 204.

9. Технологическая карта: на выполнение работ по восстановлению кирпичных, железобетонных конструкций и их защите. ООО «Композит». - К.: - 2009. -7 c.

10. Организация строительного производства: ТКП 45-1.03-1612009. [Действующий с 2014-07-01]. - Минск: Минстройархитектуры Республики Беларусь 2014. - 48 с. 
11. Технологическая документация при производстве строительномонтажных работ. Состав, порядок разработки, согласования и утверждения технологических карт: ТКП 45-1.01-159-2009 (02250). [Действующий с 2009-09-30]. - Минск: Минстройархитектуры Республики Беларусь 2009. - 16 с.

\section{Information about the author:}

Molodid O. S.,

Ph.D. in Engineering, Associate Professor, Assistant Professor at the Construction Production Technology Department, Kyiv National University of Construction and Architecture 31, Povitroflotskyi Ave., Kyiv, 03037, Ukraine 
NOTES 
NOTES 
Publishing house "Liha-Pres"

9 Kastelivka str., Lviv, 79012, Ukraine

44 Lubicka str., Toruń, 87-100, Poland

Printed by the publishing house "Liha-Pres"

Passed for printing: October 15, 2019.

A run of 150 copies. 